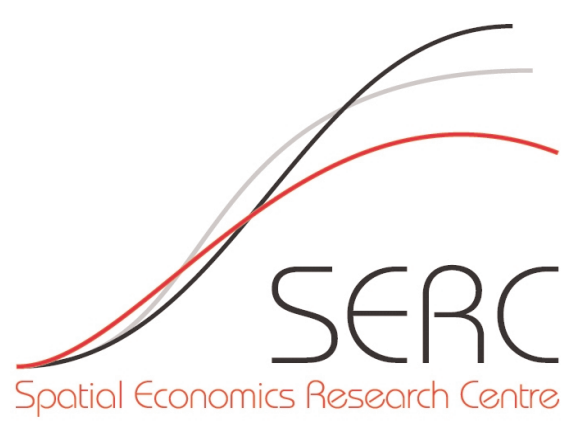

SERC DISCUSSION PAPER 226

\title{
Colonial Legacies: Shaping African Cities
}

Neeraj G. Baruah (CEP, LSE)

J. Vernon Henderson (LSE \& CEP)

Cong Peng (LSE)

November 2017 
This work is part of the research programme of the Urban Research Programme of the Centre for Economic Performance funded by a grant from the Economic and Social Research Council (ESRC). The views expressed are those of the authors and do not represent the views of the ESRC.

(C) N.G. Baruah, J. Vernon Henderson and C. Peng, submitted 2017. 


\section{Colonial Legacies: Shaping African Cities \\ Neeraj G. Baruah* \\ J. Vernon Henderson** \\ Cong Peng***}

November 2017

* Centre for Economic Performance, London School of Economics

** London School of Economics and Centre for Economic Performance

*** London School of Economics

We gratefully acknowledge the support of an Africa Research Programme on Spatial Development of Cities at the LSE and Oxford, funded by the Multi Donor Trust Fund on Sustainable Urbanization of the World Bank and supported by the UK Department for International Development. We benefited from helpful comments on an earlier version of the paper by David Weil, Matt Turner, Diego Puga, Henry Overman, and Gary Libecap, and suggestions by Andre Shleifer, Alain Durand-Laaserve, and Sameh Naguib Wahba. We also received helpful comments from seminar participants at The World Bank, University of California Berkeley, LSE and University of Oxford. We are grateful to Nicolas Cerkez for his excellent research assistance. 


\begin{abstract}
Differential institutions imposed during colonial rule continue to affect the spatial structure and urban interactions in African cities. Based on a sample of 318 cities across 28 countries using satellite data on built cover over time, Anglophone origin cities sprawl compared to Francophone ones. Anglophone cities have less intense land use and more irregular layout in the older colonial portions of cities, and more leapfrog development at the extensive margin. Results are impervious to a border experiment, many robustness tests, measures of sprawl, and sub-samples. Why would colonial origins matter? The British operated under indirect rule and a dual mandate within cities, allowing colonial and native sections to develop without an overall plan and coordination. In contrast, integrated city planning and land allocation mechanisms were a feature of French colonial rule, which was inclined to direct rule. The results also have public policy relevance. From the Demographic and Health Survey, similar households, which are located in areas of the city with more leapfrog development, have poorer connections to piped water, electricity, and landlines, presumably because of higher costs of providing infrastructure with urban sprawl.
\end{abstract}

Keywords: colonialism, persistence, Africa, sprawl, urban form, urban planning, leapfrog JEL Classifications: H7; N97; O1; O43; P48; R5 


\section{Introduction}

This paper will show that the spatial structures of cities in Sub-Saharan Africa are strongly influenced by the type of colonial rule experienced. Francophone cities are more spatially compact, with less sprawl and less scattered land development. New developments are less fragmented and disconnected from the rest of the city. Our main findings are based on a sample of 318 cities in 15 former British and 13 former French colonies in Sub-Saharan Africa (excluding South Africa). Using data from 1990, 2000, and 2014, we find that the Burchfield et al. (2006) city-level measure of sprawl - openness - is higher in British cities on average by over $22 \%$. Within cities, Francophone cities have much more intense development at the centre and intensity declines sharply with distance from it. In contrast, British cities have $75 \%$ less intense development at the centre and almost flat intensity throughout the city. Along with much higher intensity of land use nearer the centre in older colonial sections, Francophone cities have more of a 'Manhattan' gridrion structure to roads. At the extensive margin of urban development post 1990, we identify new patches of development which can be broken into in-fill and extensions of prior developments versus disconnected, or leapfrog [LF] developments. We find British cities have respectively $72 \%$ and $27 \%$ higher counts of LF patches and higher ratio of LF to total number of patches of new development. Relative to their Francophone counterparts, Anglophone cities tend to sprawl and leapfrog, as though they were an African Houston or Atlanta.

Why are there such differences? Central to our analysis is the idea that institutions affect urban spatial structures, road layouts, and the degree of compactness. Evidence in the literature suggests that, during the colonial era, the French imposed more centralisation and uniformity in urban governance, with standardised land use planning over the whole city which encouraged compactness and use of an integrated road grid system. The British had more decentralised development within cities, subject to less overall control and planning. The differences in process which reflect aspects of differences in colonial legal 
systems continue to affect city lay-outs today in two ways. First, Francophone cities were laid out differently and path-dependent historical infrastructure decisions impact urban form for decades. Public capital stocks are long lived and rights of way for roads which are key to laying out a city once established are usually followed, given the high costs of acquiring new rights of way in an already built-up city. Persistence due to prior infrastructure could go beyond the older sections of cities, since post colonial lay-outs may follow existing types of patterns as accretions of older developments. However there is a second influence: the persistence of colonial institutions and norms, with continuation of different legal systems and post-colonial training of urban policy makers.

Colonialism in Africa gives an experiment in which initial institutions are given by the happenstance of what colonial power a city fell under. Trying to distinguish persistence due to long lived physical form versus persistent institutions is difficult, but the context arguably offers an opportunity. In the older colonial areas of the city, persistence may be due to both persistence of physical stocks and of institutions. However the rapid growth of African cities driven by urbanisation allows us to look at what happens at a clear extensive margin, where there is less likely to be persistence of the physical. For 111 cities of the 318 of our cities which are included in the World Cities Data set ${ }^{1}$, population grew by $550 \%$ from 1960 to 2000, with approximately the same growth rate of Anglophone and Francophone cities. For 249 of our cities for which we have a 1975 measure of the built cover area, built cover grew by $145 \%$ from 1975 to 2014 .

Why does urban spatial form matter? The literature argues that how cities are shaped and sprawl affects how we live: whether we attain efficient density in the face of communication or social interaction externalities (Rossi-Hansberg, 2004; Helsley and Strange, 2007); how much we pollute (Glaeser and Kahn, 2010); how much time we spend commuting (Harari,

\footnotetext{
${ }^{1}$ http://www.econ.brown.edu/Faculty/henderson/worldcities.html
} 
2016); and how we interact socially (Putnam, 2000), with sprawl argued to lower positive density externalities, increase pollution and commuting times, and enhance social isolation. On the direct public policy side, planners argue that compactness lowers the cost of providing public services and urban infrastructure outlays. Compact cities require less infrastructure per person in the form of roads and utilities and the opportunity to operate mass transit systems more effectively, with the planning literature offering assessments of the savings from compactness (e.g., Trubka et al. (2010) and Calderón et al. (2014)). Hortas-Rico and Solé-Ollé (2010) provide econometric evidence for Spain in support of the idea.

While this paper offers a positive assessment of compact cities, it is clear there are many ways to live and enjoy life in cities. Apart from Hortas-Rico and Solé-Ollé (2010), there is little econometric evidence on the virtues or not of compactness and evidence can be more nuanced. For example, using data on German neighbourhoods, Burley (2016) corroborates Putnam's hypothesized correlation between socialisation and neighbourhood density, but also presents panel data evidence to suggest that sorting may explain most of this: more social people move to denser neighbourhoods which facilitate socialisation. Of course that means greater density is of benefit to social people.

In looking at development in African cities today, we add a piece of evidence which suggests that urban form and compactness have implications for public service provision. We use Demographic and Health Survey data on utilities in a variety of African cities and find that families have worse connections to electricity, phone landlines, piped water, and city sewer systems, if they live in areas of a city which have more leapfrog development, presumably because of increased cost of infrastructure provision. For hundreds of millions of Africans as they urbanise, the institutions and history under which this happens will affect how they live their lives for better or worse. While we offer a positive view on compactness, for those with a more ambivalent or negative view, the main point remains: colonial origins 
have a strong lasting influence on the way people live in African cities, and mostly likely other parts of the world.

Our various results are robust to different samples and definitional choices which we will discuss below, to deal with issues of city age, city definition, different takes on the colonial division of Africa, and the like. Our OLS results face the issue of whether the differences arise solely because of colonial heritage or whether there are omitted variables that contribute to this difference. To try to answer this issue beyond having a very extensive set of controls, for the key outcome we conduct a border experiment identifying and matching cities within $100 \mathrm{kms}$ of borders between different pairs of Anglophone and Francophone countries. We find as strong effects for this border sample.

In the paper after a discussion of institutions and the literature, we first establish that Anglophone and Francophone cities have quite different overall urban forms in terms of general measures of openness and sprawl. Then we divide the analysis into two parts. In the first we look specifically at older, more likely colonial sections of cities to establish strong differences there, reflecting at least in part the persistence of the colonial physical setups of cities. Then we turn to the vast extensive margins since 1990 of these rapidly growing cities, way past the colonial era. We introduce a new measure of leapfrog development to establish that Anglophone cities experienced much more leapfrog type development than Francophone cities over the last 25 years. Finally we will look at the impact of leapfrog development and hence sprawl on public utility provision.

\section{Colonial legacies: Urban Institutional Choice}

The literature on institutions and persistence (e.g., Banerjee and Iyer (2005) and Guiso et al. (2016)) argues that historical institutional accidents can have a strong impact on modern 
day outcomes. ${ }^{2}$ Institutional choices and historical colonial rule have been documented to be significant for contemporary economic development and political stability (Acemoglu et al., 2000; La Porta et al., 2004). More specifically La Porta, Lopez-de-Silanes and Shleifer (2008) argue that having French civil law as opposed to British common law imposed has resulted in differences in regulatory outcomes, banking procedures, property rights enforcement and the like and these differences in turn negatively affected economic outcomes. They argue that French civil law operates to control economic life and remove disorder with less concern for dictatorship (p. 307). Mahoney (2001, p. 505) argues that given the ideological differences underlying the two legal systems, French civil law is more "comfortable with the centralized activist government." Here we examine directly the effect of the imposition of colonial institutions on something as concrete and granular as urban spatial structure. In arguing that these institutional differentials resulted in Francophone cities being more compact, we have potentially a dimension where French central control produced social good. ${ }^{3}$

Consistent with the economics literature, a substantial literature on the history of urban planning in Africa argues that the French compared to the British adopted more centralised and standardised urban institutions within cities. Much of this literature is based on contrasting the 'indirect rule' strategy of the British with French 'direct rule'. The British operated under a dual mandate system and dual structure of local government, under a strategy of indirect rule (Njoh, 2015). Home (2015) develops this theme in detail for Anglophone Africa and other parts of the British Empire: "Native authorities would continue to govern the native population, while townships, largely based on the cantonment model, accompanied the colonizers ... Land laws distinguished between on the one hand, the plantation estates and townships of the European colonizers, and, on the other hand, indigenous

\footnotetext{
${ }^{2}$ There is the specific work on Francophone and Anglophone colonial legacy within a small area of Cameroon (split into parts which are former British and French colonies) as affecting wealth and water outcomes Lee and Schultz (2012).

${ }^{3}$ In a different vein, Acemoglu, Cantoni, Johnson and Robinson (2011) argue that the imposition of French civil law in the 19th century on areas of Germany which had remnants of feudalism and elitist extractive institutions improved subsequent economic growth (Acemoglu et al., 2011). We have no comment on how colonial rule in general impacted African cities per se, just on the differential impact of two types of rule.
} 
or customary land under the dual mandate approach...." (p.55, 57).

Driven to establish dominance over their colonies and with the stated aim of cultural association and assimilation, French institutions were set up with a goal of bringing all urban land under one control, supplanting all indigenous institutional structures and practices with French varieties, and bringing all public service provision under the local colonial government (Njoh, 2015). While the French may not have always truly adopted a direct rule strategy, any indirect rule was more supervisory of local chiefs than the advisory role under British rule (Crowder, 1964). Durand-Lasserve (2004) writes about the urban dimension to the direct control strategy: "Customary land management is not recognized.....In former French colonies, this situation is clearly linked with conception of freehold as defined in the Code Napoleon, and with the French Centralist political model. It is characterised by: (i) state monopoly on land, and state control over land markets and centralized land management system...."

We interpret these writings as indicating that, at the local level, the French imposed more centralised city planning and land use management, compared to the more hands-off British approach. That does leave open a separate issue of the operation of land markets and how effective the French were at replacing customary rights with private rights. Our focus is more on the the impact of centralised planning and urban lay-out. We also note that, like other European occupiers, the French promoted racial spatial segregation with Europeans often on higher ground. However, largely driven by military considerations and a desire to maintain social order and control over the landscape, the French wanted the different neighbourhoods spatially integrated and linked in a lineal pattern so that from one intersection an official could see $2 \mathrm{kms}$ in four directions (Njoh, 2015, chap. 1). Silva (2015) also writes about how the French adopted centralised and standardised grid systems. 


\section{The literature on local governance, urban structure and sprawl}

The local public finance and urban economics literature looks at aspects of the issue of compactness and leapfrogging. Theory papers analyse the role of an authority with overall control in metropolitan area governance, as opposed to there being either pure laissez faire or decentralised governance. There are also empirical papers which examine aspects of the situation.

\subsection{Theory literature}

An older literature argues that centralised governance by a benevolent city planner will lead to proper internalisation of externalities and provision of localised public goods overall for a city ${ }^{4}$, but it does do not deal with sprawl or density. Brueckner (2001) and Brueckner (2005) note that uncoordinated developers will take advantage of the fact that congestion is unpriced, public infrastructure is subsidised resulting for example in ribbon developments sited along government built arterial roads, and the externality value of lost green space at city edges is unpriced. Brueckner argues that all these lead to sprawl.

Recent work examines specific externalities, typically to argue that cities under laissez faire have insufficient density. Rossi-Hansberg (2004) argues that, in the face of communication externalities which decay with distance, absent appropriate regulation, cities will lack efficient density of commercial activity near the city centre. Helsley and Strange (2007) develop a model with social interaction externalities for those traveling to work in a central business district. Either laissez faire development or developers with control over only parts of the

\footnotetext{
${ }^{4}$ Historically, Davis and Whinston (1964) argued in very general terms that zoning is needed at the metropolitan governance level to properly internalize externalities. Hochman et al. (1995) argue that, in the presence of local public goods which have different spatial areas of reach, or jurisdiction, metropolitan governance is needed for efficient allocations and financing. That paper relates to the huge literature on decentralization of governance within countries (see a summary in Oates (1999) and within cities (see Helsley (2004) and Epple and Nechyba (2004) for a summary). On lineal and interconnected road systems, economics has little to say about efficiency, although Yinger (1993) has a model of grid layouts.
} 
city result in inferior outcomes compared to a benevolent city planner, who achieves higher intensity of residential land use. In sum, Rossi-Hansberg (2004) and Helsley and Strange (2007) present powerful arguments that uncoordinated and decentralised land development will result in cities that are less compact as an empirical prediction, with the normative overtone of being less efficient. That said, these papers don't model the political forces needed to induce an omniscient planner to behave benevolently. Nor are they planning papers dealing with the details of city spatial lay-outs and road systems.

Key parts of our paper focus on the issue of 'leapfrogging', examined in two recent theory papers. Turner (2007) examines whether neighbourhoods on the urban fringe will have leapfrog commercial developments. Henderson and Mitra (1996) consider a city with spatially decaying communication externalities across firms and strategic competition by developers setting up new developments on the city fringe. Such developments may be contiguous to old ones or leapfrog. Both papers argue that higher intensity of development in the core city is associated with lower likelihood of leapfrog development at the extensive margin.

\subsection{Empirical literature}

A key paper by Libecap and Lueck (2011) uses a border methodology to study the allocation of rural land in Ohio under a 'metes and bounds' system versus a rectangular survey system. The former is a decentralised system with plot alignments and shapes defined by the individuals claiming the land, while the latter involves centralised and regularised demarcation of surveyed plots. The authors generally find subsequent strong coordination benefits and reduced transaction costs due to regularity, which they show metes and bounds is less likely to achieve. Their exploration of land demarcation systems in rural areas presents two implications for urban areas. First, similar land institutions in urban areas may be distinguished by their degree of centralisation and standardisation. Second, a more centralised and standardised system in an urban area such as imposing a road grid pattern leads to 
greater contiguity of the urban spatial structure (Libecap and Lueck, 2011; Ellickson, 2012). The parallels to colonial land demarcation systems were extended more directly to cities by O'Grady (2014), focusing on an example comparing a centralised and standardised rectangular grid demarcation with a more laissez faire demarcation system. The idea is that the aggregation properties of rectangles without gaps or overlaps promotes contiguity of the spatial structure. O'Grady (2014) shows that, for New York City, neighborhoods with a greater fraction of rectangular grids imposed centrally and historically then experienced higher future land values and more compactness, or higher density of use.

Other papers examine persistence in spatial outcomes driven by historical infrastructure investments, with Bleakley and Lin (2012) looking at the effect of location of portage areas in the Eastern USA and Brooks and Lutz (2014) looking at the effect of the location of historical tram stops on future local clustering of economic activity within Los Angeles. ${ }^{5}$ The key paper on sprawl by Burchfield et al. (2006) analyses geographic and historical influences on the degree of land use sprawl in US cities. Shertzer et al. (2016) argue that 1923 Chicago zoning ordinances have a bigger effect on the spatial distribution of economic activity today than geography or transport networks in Chicago. Redfearn (2009) looks at how land use patterns in USA cities are driven by historical uses.

\section{Context and Data}

\subsection{Colonial countries}

Our classification of African countries by colonial origin is shown in Figure 1a along with the cities in our sample. The division is not always straightforward. World War I changed the colonial map, with former German colonies being split among the French (e.g., most of

\footnotetext{
${ }^{5}$ Michaels and Rauch (forthcoming) look at the differential influence of the fall of the Roman Empire in France versus England on urban population size and growth centuries later, based on the notion that French Roman settlements persisted after the fall, while British ones due to political upheavals disappeared almost immediately.
} 
Cameroon) and British (e.g. Tanzania), with many complex splits vis a vis modern countries (e.g., Togo). If we think governance procedures and urban plans were developed near the end of the 19th century and early 20th before the end of World War I, those procedures could set the tone for decades to come. We would then face the problem of German influences confounding the picture. Omission of these countries in robustness checks has no impact on results. While some approaches to governance and land allocations are in place well before World War I, cities were typically in infancy, so the pre-World War I influence may be limited.

\subsection{Data on land use and cities}

We utilise three epochs of land cover data - 1990, 2000, and 2014 - which classify pixels of $38 \mathrm{~m}$ spatial resolution into different uses where our general focus is on built cover (impervious surface) versus non-built cover (water, various vegetation and crop, barren water and so on). These data are constructed from the Global Human Settlement Layer (GHSL) - a new global information baseline describing the spatial evolution of the built environment, a project which is part of the Global Human Settlement Project by the European Commission and Joint Research Centre (Pesaresi et al., 2013). It is the most spatially global detailed dataset on built cover available today. While the data are based on open access Landsat satellite imagery ${ }^{6}$ available since 1972 (Ban et al., 2015), the GHSL estimates the presence of built-up areas in different epochs (1975, 1990, 2000 and 2014) ${ }^{7}$, using supervised and unsupervised classification processes based on a combination of data-driven and knowledge-based reasoning. 8 See Pesaresi et al. (2013) and Pesaresi et al. (2016) for details. For built up

\footnotetext{
${ }^{6}$ Landsat data is typically available at $30 \mathrm{~m}$ spatial resolution. GHSL employs an information fusion operating procedure based on a tiling schema to combine the source Landsat imagery with other data. Discrete zoom levels of the adopted tiling schema imposes further restrictions on effective data resolution - the GHSL project adopts a nominal spatial resolution at the equator of $38.21 \mathrm{~m}$ which best approximates the native $30 \mathrm{~m}$ of the Landsat imagery. Please see Pesaresi et al. (2016) for more details.

${ }^{7}$ Pre-processed Landsat scenes were collected for the epochs (1975, 1990 and 2000) from the Global Land Survey (GLS) at the University of Maryland (Giri et al., 2005) and were combined with Landsat scenes for the 2014 epoch to create the spatio-temporal composite. The epochs that characterise the builtup GHSL data approximate the temporal dimension of the GLS data. Epochs signify a time-period range around a given year from which the best available Landsat scene is drawn. For instance, the 1990 epoch for a city $i$ may be drawn from 1988, while it may be 1992 for city $j$.

${ }^{8}$ Spectral, textural and morphological features are extracted and a supervised classification method relying on machine learning is employed using a global training dataset derived from various sources at different scales - from publicly available
} 
cover we have two types in any year, the stock of built cover from the prior period (defined to also be covered in the current and subsequent time periods) and new cover built since the last period, which we use to analyse the nature of new development.

In applying these data, we have a base sample of 333 cities, of which 106 are former Francophone cities and 227 former Anglophone cities, with the latter including 122 Nigerian cities. These cities are reported in Table A1 and shown in Figure 1a. These 333 cities are all cities in the relevant colonial origin countries which are over 30,000 in estimated population in $1990,{ }^{9}$ which have built cover data for years of 1975, 1990, 2000, and 2014 and are defined by places within a night lights boundary. We use Citypopulation.de to get city population numbers (based on Censuses), supplemented with data from Africapolis for Nigeria. The Appendix gives details. We set 30,000, because across countries and time there is a difference in population cut-off points for reporting on city populations; a 30,000 cut-off provides more consistency in reporting. We also wanted cities likely to have some degree of maturity to urban spatial development and planning (or lack thereof). We then apply criteria on the extent of persistent cloud cover to get cloud free city-year observations for 2000 and 2014 . 10 Removing cities with cloud cover and hence only partial coverage for land cover, in 2000 we have 299 city observations and in 2010 we have 307, with a total of 318 out of 333 cities in one year or the other.

From the base sample, we explore various sub-samples, some noted here. One is West Africa which is distinct as seen in Figure 1a, in that it contains most of the Francophone countries. Another sub-sample excludes Nigeria which is a third of the sample, to make sure

and validated coarse-scale global urban data (MODIS Global Urban Extents, MERIS Globcover and Landscan among others) to more fine-scaled and volunteered geographic information (Open Street Maps and Geonames).

${ }^{9}$ These are based on population censuses around 1990 and with growth to 1990 generally based on city population growth rates between two relevant population censuses.

${ }^{10}$ We require the city-year to be $95 \%$ cloud free in 1990 for initial stock variables and $100 \%$ free in 2000 and 2014 for flow variables. We lose 49 city-year observations from imposing the 0 cloud cover restriction and 11 more from requiring no more than $5 \%$ cloud cover in 1990. If we imposed a 0 cut-off in 1990 for cloud cover, there be a loss of another 65 cities. We use the 1990 built cover within our cities at times as a control variable, when looking at flows to 2000 or 2014 . Since 1990 defines 2000 pre-built area, in the 2000 analysis any 1990 cloud cover areas in a city are dropped from the calculations for that city. 
it is not driving the results. A third is to look at newer cities whose origins appear to be colonial (from the French-British era) and founded after 1800, based on web scrapping of information. These cities are denoted in Table A1. We expect and do get stronger results for cities which are more subject just to colonial influences. Finally, there is a sample for Open Street Map analysis of all Francophone cities over 300,000 in 2012, with the size bound imposed to ensure more reliable OpenStreet map data which are new to Africa. These 20 cities are then propensity matched to 20 Anglophone cities which have similar populations, growth, coastal location or not and the like. We will use these to analyse differential urban structure and road lay-outs in the colonial portions of larger Francophone versus Anglophone cites. These cities are listed in the Appendix and mapped in Figure 1b.

\subsection{Data on geography and the extent of the city}

In applying these data, we must define the spatial extent of cities. Since outcome measures involve aspects of the built environment, we do not want to use a measure based on built cover per se to define the extent of the urban area. We will note later how that biases results, by tending to omit extensive margin developments which are more leapfrog in nature as opposed to infill and extension. We rely on night light readings for Africa (Donaldson and Storeygard, 2016; Henderson et al., 2017) and define the city to be the area within the outer envelope of all areas lit for at least two of the last 5 years from 2008-2012. African cities have generally low light levels, so we do not threshold the lights to be above some cut-off. For smaller cities thresholding excludes obvious built areas (looking at Google Earth) and even some entire cities. In very big cities blooming is an issue and the lights boundary can include large undeveloped areas and cover satellite towns. In robustness checks, some reported in footnotes and appendices, we experimented with imposing light thresholds, setting distance limits over which we look, and trimming the cities with high maximal and low minimum distances from the centre to the farthest edge. For bigger cities a lights cut-off of zero captures ribbons of satellite towns developing along transport arteries going out from a 
city, which these robustness experiments tend to exclude. We also use night lights to define the city centre, as the brightest lights pixel (about $.8 \times .8 \mathrm{kms}$ square near the equator) in 1992/93. We note also that we defined smoothed built cover boundaries for cities as defined in the Appendix for 1975, 1990, 2000, and 2014. The 1990 measure gives an urban core, beyond which in the extensive margin we will find over $98.5 \%$ of our post-1990 leapfrog patches.

Finally a basic identification issue is whether Anglophone cities differ from Francophone because of colonial origins or because of differential underlying geographic conditions of cities which influence urban layout, regardless of colonial origins, noting that Burchfield et al. (2006), Saiz (2010) and Harari (2016) all show that geography influences urban form. ${ }^{11}$. For geography, we use measures found in different literatures, but primarily based on based on Burchfield et al (2006). First we are concerned about terrain where hilly terrain spreads out developments around inaccessible terrain. We have a basic measure of ruggedness as defined by Nunn and Puga (2012) and of the range of elevation within the city. Water is another constraining feature. We have distance to the coast from the city centre; and, if the city is coastal, the kms of coastline within its boundary, where extensive coast means more inlets and bays again influencing city shape (Harari, 2016) . In the land portion of the city we know the fraction of pixels that are inland water (lakes, rivers, wetlands). In some specifications, we then draw a $5 \mathrm{~km}$ buffer around the outer edge of the city land area. In that buffer we try to catalogue the percent of the buffer in different uses in the base period: forest, shrubs, crops, water and wetlands, and sparse and bare vegetation (compared to grasslands). This reflects an issue of the opportunity cost of city land (which could vary systematically between Francophone and Anglophone). For that reason we also utilize the rainfall average from 1950-2000. The hardest items to deal with are growth and economic opportunities for the city. We have initial population size (estimated 1990 population) and

\footnotetext{
${ }^{11}$ There are also social conditions and in a developed country context we might worry about differential attitudes towards use of the automobile and the development of sprawl. First we note that even in seven major Sub-Saharan African cities, automobiles presently account for under $15 \%$ of trips (Trans-Africa Consortium, 2010). Second, that fraction would have been even smaller in the colonial era.
} 
lagged country level GDP per capita. For a city growth control, we are concerned about reverse causality so instead of focusing on growth in city lights at night (Henderson et al., 2012), we utilize growth of lights in the country, excluding the own city. Finally we have base 1990 land cover in the city.

\section{Overall patterns in the data for cities as a whole}

Using the GHSL Landsat based data, first, we correlate two common measures of sprawl with Anglophone colonial origins to see motivating patterns in the data. We examine the openness index from Burchfield et al. (2006) for the overall city and then examine intensity of built land use by distance from the centre. For openness, following Burchfield et al. (2006), for each built-up $38 \mathrm{~m}$ x $38 \mathrm{~m}$ pixel in a city in a year we calculate the fraction of unbuilt pixels in the immediate $1 \mathrm{sq} \mathrm{km}$ grid square. These fractions are then averaged across all built pixels in the city. The measure reflects the extent of open space around the typical built pixel in a city. We also looked at flows, or changes in this index to address the issue of convergence.

At a more detailed level within the city, we look at intensity of use, comparing the central part of the city with areas further out, in $1 \mathrm{~km}$ ring intervals. To measure intensity, we divide the city into a $500 \mathrm{~m} \times 500 \mathrm{~m}$ grid. Intensity is the count out of the approximately 173 pixels in each grid which are built cover. We then aggregate to rings and examine the stock ring levels of intensity in 2014 as a function of distance from the centre to get an intensity gradient, as well as looking at how intensity changes from 1990 to $2014 .^{12}$

What correlations do we see in the raw data? First, we compare distributions of openness for Francophone versus Anglophone cities for 307 relatively cloud free cities, ${ }^{13}$ based

\footnotetext{
${ }^{12}$ Aggregating to rings avoids dividing the data in a ring into three components: grid squares which are never built upon, grid squares which were built upon in both 1990 and 2014 and grid squares which were newly built upon after 1990 . In the Appendix, we show results concerning these different margins.

${ }^{13}$ These are 307 cities where the Landsat images used are 95\% cloud free in 1990 and $100 \%$ cloud free in 2014.
} 
on graphs in Burchfield et al. (2006). Figures 2a and 2b show the pdf for the distribution of built up pixels in 1990 and 2014 by the percent of land not built in the surrounding one square kilometer (i.e., openness). In both years, the dotted line for Francophone relative to the solid line for Anglophone shows the Francophone pdf's shifted left. Francophone cities tend to have a greater fraction of built pixels in areas with very low openness and a smaller fraction of pixels in areas which are very open, suggesting that Francophone development is more compact and Anglophone more sprawled. There is a hint in the graphs that the differential is smaller in 2014, raising the possibility of some convergence.

Table 1 examines the Burchfield openness index in 2014 in regressions controlling for geography and other city characteristics. Apart from the Anglophone cities effect, column 1 has no controls other than the 2014 dummy; column 2 adds most controls; and column 3 adds the rest on use of land at city edge. The Anglophone effect in column 1 is an increase in openness of $23 \%$ and with all controls added in column 3 it is $22 \%$. Clearly adding controls has little impact, which suggests fundamental differences in the geography or economies of Francophone and Anglophone cities are not driving the colonial correlation, even though some control variables have expected effects based upon the analysis in Burchfield et al. (2006). Bigger cities have less openness and cities with greater elevation differentials have more. Rainfall (opportunity cost of urban land) or related vegetation measures at the city edge tend to reduce openness. We also note that it could be that French centralised land use control may have responded to differential geography of cities differently than the more decentralised British approach. If we interact all covariates in column 3 with the Anglophone indicator and predict how a typical city with mean characterictics in the overall sample differs under the two regimes, under an Anglophone regime that typical city has $19 \%$ greater openness.

In columns 4-6 we estimate an intensity gradient. We expect land use intensity to decline 
with distance from the city centre, because the price of land declines with distance. Here adding controls actually augments the Anglophone differential. In column 6, Anglophone cities at the centre have $76 \%$ fewer built pixels. For the base Francophone cities, intensity declines at a rate of $6 \%$ per kilometer as we move away from the centre. In Anglophone cities that decline is significantly less, at net of about $1 \%$ a kilometer. Anglophone cities have lower intensity near the centre and an almost flat gradient, a good description of cities that sprawl relative to their Francophone counterparts.

Table 2 addresses the issue of city level convergence for the overall index of openness (columns 1-2) and the ring measure of intensity (columns 3-4). Table 2 shows a long difference from 1990-2014, where the odd number columns have no control for the base period level (mean reversion), while even number columns do. All columns control for all geographic variables and city characteristics variables. For openness and intensity respectively, in columns 1 and 3 without the control for initial openness or ring built cover, it looks like there is a degree of convergence. Anglophone cities become less open, with more intensified land development. But in columns 2 and 4, the British indicator is insignificant. We also tried interacting the initial openness and intensity levels with Anglophone in columns 2 and 4 respectively, which yields small and insignificant coefficients. Convergence comes from the fact that Anglophone cities are less intensely developed to begin with and have more open space. Conditioning on openness or built cover, there is no Francophone-Anglophone difference overall and at the city centre. In column 4, the degree of intensification in Francophone cities tends to decline with distance from the centre, as the opportunity cost of land declines. But there is no gradient of intensification of Anglophone cities, again reinforcing the notion that these 
cities have fairly flat intensity gradients. $14 \quad 15$

\section{The Colonial portions of cities}

\subsection{Road layouts: Anglophone versus Francophone cities}

To better understand aspects of colonial influence we start with an example, which compares Bamako to Accra. Both locations only emerge as cities in the late 19th century, Bamako under French rule and Accra under British. Their populations are similar in the early 20th century: Bamako at 16,000 in 1920 and Accra at 18,574 in 1911. ${ }^{16}$ Accra retains that modest population difference with Accra at roughly $2.3 \mathrm{~m}$ and Bamako at $1.8 \mathrm{~m}$ today. While Accra is a coastal city, Bamako is on a major river with the initial city on just one side (like a coast line). Bamako had its first (apparently implemented) road plan in 1894 (Njoh, 2007, p. 92) replacing spontaneously prior developed roads with a street network on a classic gridiron with streets intersecting perpendicularly (Njoh, 2001, p. 23). Bamako's urban land was under state control by 1907 with the "Plan d'une cite administrative - un quartier de Bamako", with the state supreme in land allocations and assignment of set plots (Bertrand, 2004). Accra proceeded under the usual British dual mandate without a comprehensive plan until The Town and Country Planning Ordinance of 1945 (Ahmed and

\footnotetext{
${ }^{14}$ In Table A2 in the Appendix we break out grid squares within rings to look at the margins of intensification: intensification in grid squares with some 1990 built area, whether 1990 undeveloped grid squares developed or not, and, if so, at what intensity. Results are consistent with the aggregation to ring approach we are using. Column 1 of Table A2 estimates a linear probability model of whether a grid square is developed or not in 2014. Columns 2 and 3 look at the sample of undeveloped grid squares in 1990 and estimates an LPM of whether they develop by 2014, with no evidence of convergence on that margin. Column 4 looks at 2014 development intensity of 1990 grid squares which had built areas, with British being lower. Columns 5 and 6 look at intensification within these 1990 developed grid squares. Again it looks like there is convergence (column 5) until we control for initial intensity. Column 7 looks at 2014 intensity in newly developed grid squares. In short there is convergence, but not beyond what would be expected from mean reversion type convergence.

${ }^{15}$ In Tables 1 and 2, one concern is that our lights boundary for bigger cities with blooming of lights at the edge is quite generous and some cities have huge maximum distances from the centre to the farthest boundary. Table A3 in the Appendix examines this issue. There, restricting the area of cities does affect the magnitudes of the slopes of intensity gradients, given we can have huge extensive margins of cities with very low development. In Table A3 we experiment with the level intensity formulation from Table 1 and the convergence, or intensification one from Table 2. We tried many cuts, all to the same affect. Table A3 shows one where we still use a zero lights boundary but cut the rings off after $30 \mathrm{kms}$ from the centre and one where we use a lights boundary of 5 and trim the top and bottom $5 \%$ of cities in terms of maximum distance from the centre to the outer lights boundary of 5 . Patterns are very similar to Table 1 and 2 . Thus with the trimming, intensity does declines more sharply with distance from the city centre. However the degree of decline remains significantly less in Anglophone cities.

${ }^{16}$ For Bamako: "France: Africa: French West Africa and the Sahara". Statesman's Year-Book. London: Macmillan and Co. 1921. pp. 895-903 - via Internet Archive. Colony of French Sudan. For Accra "Population Studies: Key Issues and Continuing Trends in Ghana" S.N.A. Codjoe, D.M. Radasa, and S.E. Kwankje, Sub-Saharan Publishers, Accra, 2014, p.115
} 
Dinye, 2011) when, according to Grant and Yankson (2002), "zoning and building codes were strictly enforced to maintain an orderly European character and ambience", especially in the European Central Business District (Ahmed and Dinye, 2011) (Grant and Paul, 2003).

Figures $3 \mathrm{a}$ and $3 \mathrm{~b}$ show the road layout in the older sections of these cities, roughly up to 4-5kms out from the city centre. For Bamako we show the 1963 road layout from tracings of road maps and the road layout today from OpenStreetMaps. For Accra we show the roads for $1966{ }^{17}$ as well as today. Inspection suggests several takeaways. First in both cities, roads that were in place 50 years ago generally remain in place today- phyical persistemce. Second Bamako presents as having large sections of intense dense, gridlike road structures where sections are interconnected by mostly long lineal roads. And 1963 fringe roads that appear to meander to the north east have in some cases been replaced by gridlike structures. New sections of the city generally are on a rectangular grid structure. In contrast is Accra. Accra shows much less grid like structure with fewer lineal connecting roads between developments even in the colonial parts of the city. And new developments on the fringes of the colonial parts of the city appear to have much less rectangularity and lineal connections than Bamako. Note that for the same map scale, we see much more of the city, its road system and lay-out for Bomako, than for sprawling Accra.

To test whether these differences hold more generally, we took all 20 Francophone cities in Sub-Saharan Africa over 300,000 in 2012, to analyse road layouts from OpenStreetMaps. Since OpenStreetMap data is relatively new for Sub-Saharan Africa, we restricted to larger cities and to mapping within 3-5 kms of the centre to try to ensure better reporting. We then chose 20 corresponding Anglophone cities over 300,000 out of the 68 in that size range, using a one to one Mahalanobis distance based matching approach without replacement. The covariates include initial city population in 1990, average rainfall from 1950 to 2000,

\footnotetext{
${ }^{17}$ The source of both old maps is Oxford Library. It is digitalized by Ramani Geosystems, a GIS firm based on Nairobi
} 
coastal dummy, absolute elevation, and city annual estimated population growth from 1990 to 2012. With matching, means of the matching variables show miminal (and completely insignificant) differences between Francophone and chosen Anglophone cities. Also in the end there are 11 Nigerian out of 20 Anglophone cities, effectively matching Francophone ones concentrated in West Africa. Other samples drawn to reduce the Nigerian count show similar if not stronger results. ${ }^{18}$.

For this matched sample we ask if the Francophone colonial sections of cities and immediate extensions have different structures than Anglophone ones, with a more regular and connected road system, which would guide the complementary layout of private investments. Here we give quantitative evidence of the more standardised grid system of Francophone cities. Figure 4 illustrates the process followed and derivation of measures. In part A we have the raw OSM road network data for part of a city and B shows the derived road blocks. Road blocks are categorised by their degree of rectangularity using the minimum bounding rectangular method of Žunić et al. (2012) and Rosin (1999). The minimum bounding rectangle is a rectangle which minimally encloses the actual block polygon. Rectangularity of a block is the ratio of the area of the block to the area of its minimum bounding rectangle - a perfectly rectangular road block would be 1 , and the ratio tends to fall as it takes on more complex shapes. Part $\mathrm{C}$ of Figure 2 ranks all the blocks in the shot - the dark blocks with rectangularity measures equal to or greater than 0.9 are ones we call rectangular blocks. We chose a cut-off of 0.9 to allow for measurement error and topography in approximating perfect rectangles.

Part D of Figure 4 shows how we define gridiron blocks, which is the basis for our main measure and captures contiguity in rectangularity of layout of sections of a city. To be a

\footnotetext{
${ }^{18}$ For example, for another project, we had a sample of 55 cities generally over 240,000 for which we obtained SPOT data which was weighted against having too many Nigerian cities and towards greater country (Francophone) coverage. Or we matched with Anglophone cities without an explicit requirement that they be over 300,000 which again weighs against Nigeria
} 
gridiron block, a block must have a rectangularity index greater or equal to 0.9 , be devoid of dangles, and be connected to all neighbouring blocks by 4-way intersections. Dangles are roads off the regular road network which lead to no connection (i.e., dead-end), or blocks with a cul-de-sac, dead-end, or T-intersection; and they are illustrated in Part E of Figure 4. Part D of Figure 2 shows in yellow the subset of rectangular blocks which qualify as gridiron. For analysis we calculate the share of gridiron blocks to all blocks in the area in question.

We believe OSM data pretty comprehensively maps roads in these 40 African cities up to about $5 \mathrm{kms}$ from city centres, covering both the colonial parts of the city which generally lie within 3 or fewer kms of the centre and post-colonial immediate extensions. Further out, mapping is expected to be of poorer quality because of the incomplete nature of volunteered OpenStreetMap information. In Figure 5, for each of these cities we show the fraction of gridiron blocks out to $5 \mathrm{kms}$ with Anglophone cities represented by the darker shades. Although the pattern is somewhat mixed, Francophone cities generally have higher shares of gridiron blocks. The visual impression is confirmed by a regression coefficient giving the average Anglophone differential. Anglophone cities average 20 percent points fewer gridiron blocks, from a mean of 17 . The sample mean is almost the same at 3 and $5 \mathrm{kms}$, so there is no overall diminishing of regularity with the 150 percent increase in area covered.

We note two other things. First results on the share of rectangular blocks are similar to those for gridiron, but we prefer the tougher criterion which captures contiguity. Second we also looked at the share of dangles. Anglophone cities have 3.5\% higher shares of blocks (for a mean of 10.7) with at least one dangle to all blocks of the area in question, but the coefficient is only significant at the $11 \%$ level. Overall the results suggest a strong colonial influence of centralised control and grid planning, as suggested by Njoh (2015) and Durand-Lasserve (2004), which persists until today ${ }^{19}$.

\footnotetext{
${ }^{19}$ One issue is whether Anglophone cities were regularly laid out but just not on a rectangular grid, using more diagonal roads with roundabout intersections. We checked the count of roundabouts within $5 \mathrm{kms}$ of the centre. On average there is
} 


\subsection{Intensity of land use in the colonial portions of cities and immediate extensions.}

Corresponding to gridlike structures of roads is much greater intensity of land use in the colonial portions and their extensions, for Francophone cities compared to Anglophone, indicating much greater compactness. In Table 3, for the full sample of cities, we show ring by ring intensity regressions for 1990, the year nearest the colonial era, as we move out from the city centre in $1 \mathrm{~km}$ increments, looking more in depth at what was reported in Tables 1 and 2. The dependent variable is the log of the total number of built pixels in each ring. Shown are the coefficients for British and for a control for the number of available pixels (built ot not) in each ring by city, which also allows for differential differential ring counts based on geography (e.g., cities on a coastline or river vs. more circular non-coastal cities). All columns control for all geographic charateristics and 1990 city population and country GDP per capita.

For rings 0-1, 1-2, 2-3 and 3-4 kms Anglophione cities have 37-78\% fewer built pixels. They are much less intensely developed. After $4 \mathrm{kms}$, the sample starts to drop quickly as we lose smaller cities with no area beyond the given radius. Second the story gets more complex. Francophone cities as we saw in Table 1 have sharply negative density gradients, while Anglophone cities sprawl. So for the same population, at some distance from the centre, Francophone cities end while Anglophone cities continue with built area. That said while there are no significant differences, for the British indicator beyond $4 \mathrm{kms}$, until $11 \mathrm{kms}$ out all but one coefficient are both negative and in the $30 \%$ range. Only at the tail reported at 11-12 kms does the British coefficient become positive, albeit insignificant. Regardless, colonial portions out to $4 \mathrm{kms}$ of Anglophone cities have much less intense land use than Francophone ones.

absolutely no difference between Francophone and Anglophone cities. 
Is there convergence in these colonial portions? In Table 4 we look at rings $0-1,1-2,2$ 3, and 3-4 with a long difference of the log intensities between 1990 and 2014. The controls include all those in Table 1 and the city ring pixel count (built or not). In columns 1-4, for each ring in succession, the reported coefficient is for the British indicator. Then in columns 5-8 for the same respective rings there is an added control of the ln count of built pixels in each city-ring in 1990. Columns 1-4 indicate a reasonable degree of convergence. Columns 5-8 suggest that convergence is again from mean reversion: areas with less built pixels will fill-in. In general there is no significant extra British effect either overall or in the degree of mean reversion. So convergence is for all types of cities where, intially lower density places fill-in more.

\section{Compactness in the (vast) post-colonial extensive margins of cities}

Differentials at the extensive margin of cities are more difficult to capture with the framework utilised above. Francophone cities have high intensity at the centre which declines sharply while Anglophone cities have fairly flat intensity gradients. Thus as noted above, for the same population, their spatial reaches differ. To deal with that problem, in the remaining parts of the paper, we focus on the extensive margin of cities post-1990 and on a concept well established in the literature, leapfrogging, with our own specific measure. Leapfrogging is a flow measure of leapfrog patches occurring under development from 1990 to 2000 and then under development from 2000 to 2014.

How do we define leapfrog development? Using the 1990 to 2000 period as an example, in 1990 we have a set of built pixels, which are typically in clusters. We define the boundary or outer envelope of each cluster of contiguously developed pixels, which we call patches (where some patches are isolated singleton developed pixels). In the illustrative Figure 6, 
the 1990 developed areas are the light shaded (orange-pink) ones. The focus is on newly developed pixels. These also appear as patches of contiguous newly built pixels, which also have boundaries. Around each bounded patch (or singleton) of newly built pixels we draw a $300 \mathrm{~m}$ buffer, effectively including all pixels or parts of which lie within $300 \mathrm{~m}$ of the nearest border of the new patch. Then we focus on the areas within (just) these buffers around new patches to define three types of new development. If that buffer area is generally contained within an existing development it is called infill (red area in the figure). If it only marginally intersects the existing cover (or is within $300 \mathrm{~m}$ of it), it is called extension (blue in figure). If does not intersect (within 300m) any existing 1990 development it is called leapfrog (green patch). Our buffer choice of $300 \mathrm{~m}$ is guided by the literature on 'walkable neighbourhoods' - most notably, Barton et al. (2003) claim a theoretical circular catchment of radius 300m (corresponding to walking time of 5 minutes) as a planning goal for urban amenities and interactions. Thus, leapfrogging occurs when a new urban patch development arises beyond the walkable distance of an existing urban patch. Of course, walkable distance is in the eye of the beholder and we experimented with different size buffers as reported under robustness checks.

Given these concepts, we have a measure of the connectedness of urban expansion, or the landscape expansion index (LEI) (Liu et al., 2010) where

$$
L E I=\frac{A_{b}}{A_{b}+A_{o}} * 100
$$

where $A_{b}$ is area of intersection between the buffer zone of a new patch with existing built cover, to give the area of already built pixels within the buffer zone of a newly built area. $A_{o}$ is the area of intersection between (just) the buffer zone itself for new patches with open space, to give the area of open space in the buffer zone. Thus the denominator is total area in the buffer zone and the numerator the built area within that. Infill might be defined 
as an $L E I>50$, so at least $50 \%$ of the buffer is already built space. Our focus will be on leapfrog patches where the LEI is 0 , so there is absolutely no already built space in the buffer surrounding new development. However first in Figure 7, we show the pdf of the LEI measure for patches of new development in all Francophone versus Anglophone cities. The Anglophone measure is much more concentrated at the low end of LEI's between 0 and $5 \%$, representing a greater concentration of leapfrog or almost leapfrog developments.

We now turn to statistical analysis and look at the absolute and relative count of leapfrog patches in a city and the area they encompass. Most critical to our claim that we are looking at the extensive margin is the fact that over $98 \%$ of all leapfrog patches in the sample lie outside the smoothed land cover boundary of the city in 1990. These are developments in areas new to the city since 1990. LP patches average about $12 \%$ of all patches but have high variation across cities (the standard deviation on the variable is 11).

\subsection{Primary results}

Given we are pooling flow data and turning to our primary results, here we do note the estimating equation:

$$
Y_{i j t}=X_{i j} \beta+Z_{i j t} \theta+\delta \text { Anglophone }+d_{t}+\epsilon_{i j t}
$$

where $i$ is city, $j$ is country and $t$ is time. We have different counts and areas of leapfrog patches in 2000 (from 1990) and 2014 (from 2000) as the dependent variable. Note leapfrogging is a flow measure for 1990 to 2000 and 2000 to 2014 . $X_{i j}$ are city $i$ factors which are either time invariant or for which we want a base period measure. $Z_{i j t}$ are time varying factors. These controls are shown in Tables 1 and $2 . d_{t}$ is a time dummy, where at a minimum it captures the fact that the second time interval (00-14) for LF patches is 4 years longer than the first (90-00). The coefficient of interest is $\delta$, the Anglophone differential. Focusing 
on flows and the extensive margin may help difference out the influence of key unobserved geographic factors. A finding of greater leapfrogging in Anglophone cities would suggest colonial patterns of disconnected and independent developments in Anglophone compared to Francophone cities persist under today's inherited institutions at a margin well beyond the physical colonial city.

Columns 1 and 2 in Table 5 show basic results for the logarithm of the count of leapfrog patches in a city. Column 1 (and odd numbered columns) has just base specification controls, while column 2 has all controls. The main result of the paper is in column 2 with full controls: Anglophone countries have $72 \%$ more leapfrog patches. Here the added controls have a modest effect in dampening results; coefficients are about $20 \%$ smaller in column 2 than in column 1. In the specification, there is a small count of about $5 \%$ of observations which are zeros which we set to the minimum of 1 (so the log is zero). Results in the Appendix Table A4 show OLS results excluding these zeros, Tobit results, and Poisson count results. The Anglophone effect remains basically unchanged. ${ }^{20}$ We also note the issue again that Francophone regime cities have respond to differential geography of cities differently than the Anglophone ones. If we interect all covariates in column 2 with the Anglophone indicator and predict how a typical city with mean characterictics in the overall sample differs under the two regimes, under an Anglophne regime that typical city would have $68 \%$ more leapfrogging.

In columns 3 and 4, we show results for the log (count LP patches/ count total patches). The coefficient on the ratio in column 4 is $0.27 .{ }^{21}$ This implies the marginal effect on all patches for Anglophone (over Francophone) cities is about 0.45 (0.72- 0.27). British colonial cities develop more by building in greenfield areas, rather than intensifying already built cover

\footnotetext{
${ }^{20}$ The effect is about $30 \%$ smaller for the Poisson but, by comparison to other columns that is clearly due to Poisson functional specification.

${ }^{21}$ For the typical city under a specification where all covariates are interacted with the Anglophone indicator, the differential is $22 \%$.
} 
in general, or have more patchy development. But, given that, they are even more prone to these patches being leapfrog ones. In columns 5 and 6 we show results for log (average area of LP patches), which checks whether Anglophone patches are somehow bigger, so they might be easier to service. There is no average size difference in leapfrog patches between the two types of cities. In summary Anglophone cities have more patchy development at the extensive margin, especially leapfrog development, where these leapfrog patches are no bigger or smaller than their Francophone counterparts.

\subsection{Identification}

Are the effects in Table 5 causal? In part we are arguing causality through the weight of different pieces of evidence and the use of a large set of controls and flow data, but biases obviously may remain. Although the insertion of many controls has little impact on the Anglophone 'treatment', the characteristics between the Anglophone and Francophone sets of cities are not balanced in all cases, suggesting there could be unobservables affecting outcomes which are also unbalanced. To deal with this we turn to a border experiment, to try to compare Anglophone versus Francophone cities facing identical circumstances.

Figure 8 shows West Africa where 5 Anglophone countries share borders with a number of Francophone countries. At these borders there are no significant waterways. We show cities within a $100 \mathrm{~km}$ buffer of the borders involved. Results are almost the same if use a $125 \mathrm{~km}$ or $150 \mathrm{~km}$ buffer. We chose the smaller buffer, but dropping below $100 \mathrm{kms}$ loses too many cities. To refine the border experiment, we break border segments into 15 finer portions, grouping cities into natural clusters of cities that are very near to each other, to try to control for unobserved geographic or other influences. These clusters are given in Figure 8. Two of the 15 contain only one type of colonial city and as such are neutralized by their cluster FE's. An issue for country borders is that part of Francophone Cameroon (orange border) was under British control after World War I through to the mid-1960's. We 
do the analysis both excluding this area (which is 1 cluster) and treating the border between Anglophone and Francophone Cameroon as the true border. We think it is better to exclude the area. Clearly the Anglophone Cameroon cities have conflicting effects: British heritage versus French rule for 50 years.

With these 15 clusters, have we attained balance? Table A5 shows our key covariates from Column 2 of Table 1 regressed on a constant and the Anglophone indicator. To key covariates we add the ratio of 1992 lights to 1990 population as a crude measure of city GDP per capita and city lights growth from 1992 to 2014 as a city growth measure. In Table A5 we show that for the full sample there is a lack of balance for many covariates. With the border sample considered here only 2 of 11 covariates differ in mean for Anglophone cities and once we add the 15 cluster FE's, only one of 11 differs.

In Table 6, we run the same leapfrog regressions as in Table 5 with a full set of controls. We show the results for a base case without FE's in columns 1 and 3 and then in columns 2 and 4 we add the cluster FE's. Results compare 37 Anglophone cities with 30 Francophone cities for the full sample and 35 Anglophone and 23 Francophone cities when we drop the Anglophone-Francophone Cameroon segment. In each of the three rows we show the outcomes: $\log ($ count of LF), and $\log$ (ratio of LF to total count) and log (average area of leapfrog patches). First the exclusion or inclusion of the controversial area of Cameroon makes a modest difference, with stronger effects in columns 3 and 4 when we drop the controversial Cameroon area. We focus on those. In Table 6, the Anglophone degree of leapfrogging is significantly higher in both specifications with somewhat larger point estimates than in Table 5: 0.86 for the city-cluster FE's in Table 6 versus 0.70 in Table 5. For the ratio of leapfrog to all patches, results are statistically weaker, but magnitudes higher than in Table 5 (0.45 versus 0.27$)$. As is the case in general, areas of patches do not differ by colonial origin. Overall Table 6 is strong evidence that it is colonialism and not other factors driving 
our results.

\subsection{Robustness}

The next issue is robustness of Table 5 leapfrog results to other considerations. For that we turn to Table 7 . In Table 7 in column 1 we show the base case. As in Table 5, in each of the three rows we show the outcomes: log (count of LF), and log (ratio of LF to total count), and $\log$ (average area of leapfrog patches). In columns 2 and 3, first we experiment with types of leapfrog measures. Column 2 removes from the counts and areas any

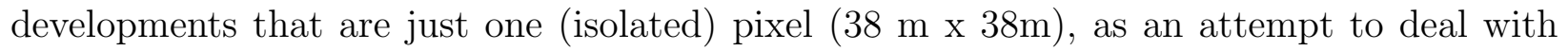
obvious impacts of mis-measurement of built cover. Column 3 uses a buffer around newly built areas of $60 \mathrm{~m}$ rather than 300m in defining LEI and LF developments. In both cases, the impact on point estimates is minimal. The rest of the columns deal with sampling issues.

Column 4 worries about blooming of night lights in bigger cities, which then add non-urban areas within the lights boundary, where Anglophone versus Francophone differentials might exist for other reasons. Column 4 uses city light boundaries cut at 5 and a dataset where we trim the top and bottom $5 \%$ of cities in terms of maximum distance from the centre to any part of the lights boundary. Again that has little effect on results in all 3 rows. We note however (but not shown in the table), that if we defined the area of the city as a smoothed 2014 built area cover, that would bias our results. For the leapfrog count outcome, the coefficient is minimally affected, but the ratio of LF to all patches then has a coefficient of zero. By cutting on smoothed cover, we mechanically tend to exclude areas with more leapfrogging relative to other patches.

Columns 5 and 6 turn to different country samples which are potentially more problematic. Column 5 removes countries which were initially German colonies before being assigned to Britain or France after World War I. Dropping those countries (Namibia, Tanzania, Togo, 
and Cameroon) has little effect on results. Similarly dropping Nigeria which is a big portion of the sample has little impact on the Anglophone coefficients for any of the 3 outcomes. Column 7 looks at colonial origin cities, which were built after 1800 and appear to be colonial constructs. Point estimates here are much larger, hinting at much stronger differences for cities built from scratch under the different colonial regimes, although the sample is small. But the intuition is appealing. Column 8 focuses on the sample of 40 cities for which we assembled OpenStreetMap data. Here the point estimates on absolute and relative LF counts are somewhat larger than in column 1, but the results for this sample are not out of line with the rest of the data. That is reassuring for the applicability of the gridiron results.

In sum, throughout, the basic bottom line is that the extensive list of robustness checks and the border experiment suggest the quantitative LF results hold under different measures and samples and experimental contexts. Secondly in the one case where they differ enormously, it makes sense: much stronger results for colonial origin cities.

\section{The so-what question: Public policy relevance}

The planning literature argues that having compact and more regularly laid out cities lowers the cost of infrastructure provision. In Africa we would further argue that higher costs will lower the likelihood of receiving public infrastructure provision. To assess the reduced form impact, we use DHS data on whether a family has a piped water connection (with the alternatives being a shallow or deeper well or having no water connection), an electricity connection, a telephone land line connection, or a (flush) toilet connected to a public sewer system. The last two are less frequent to begin with. DHS uses cluster sampling of 20-30 households in a neighbourhood and we restrict attention to clusters defined by DHS to be in urban areas. We cover 21,016 households in 745 clusters in 115 cities in 9 countries. Of the 115 cities, only 16 are Francophone. The focus here is not on Francophone versus 
Anglophone per se; but, rather, the impact of leapfrogging within any city on public utility provision. Virtually every survey we use asks about all four public utility connections of the household.

The challenge in implementation concerns location. Within an urban area, cluster locations are randomized within $2 \mathrm{kms}$ by randomly picking a directional ray (angle) from the true cluster centre and then choosing a location randomly along that ray within $2 \mathrm{kms}$ of the cluster centre. Under this algorithm, while locations near the true location are more likely to be chosen, the randomized location is equally likely to be in any ring out from the true location up to the $2 \mathrm{kms}$. We draw a $2 \mathrm{~km}$ circle around the specified location and look at the existence and frequency of leapfrog patches conditional on how developed that circle is, how far it is from the city centre, and other controls. One could view this as a measure of how likely a cluster is to be in a leapfrog patch, but we interpret it as a measure of the overall degree of leapfrog development in the surrounding area. To exploit economies of scale in construction, cities roll out public utilities in large spatial zones. The higher the degree of leapfrog development in an area, the less likely it is to be serviced, because roll-out is more costly. Regardless, because of the randomization of location, the variables of interest are measured with error. We could not think of an instrument which both met the exclusion restriction ${ }^{22}$ and has power (e.g., being a Francophone country). Given the measurement error involved we did not anticipate getting strong results. However we were surprised.

The results are in Table 8 covering about 21,000 household for each attribute. In a linear probability formulation, each attribute has two columns. The first (odd numbered) column has basic supply controls, with our variables of focus: whether there are nearby leapfrog developments and, if so, how many. The second column (even numbered) controls for household demand characteristics, which only serve to strengthen the results. The count

\footnotetext{
22 e.g. Using the propensity of surrounding areas to have LF development for whether cluster is recorded in a leapfrog patch does not.
} 
of leapfrog patches significantly reduces the likelihood of an electricity connection and a landline connection and with weaker significance reduces the likelihood of a piped water connection. The sign on flush toilets is negative, but the results are insignificant. Effects are not huge, given attenuation bias. On the count of leapfrog patches, for electricity it is -0.009 from a mean likelihood of 0.76 (although there is a base leapfrog indicator effect of $-0.04)$; for landlines a -0.004 from a mean of 0.05 ; and for water -0.004 from a mean of 0.5. Using a radius of $3 \mathrm{kms}$ to describe the degree of leapfrog development in the surrounding area yields significant results for all 4 outcomes, but magnitudes of coefficients are lower for the first three outcomes. Overall, effects are consistent, suggesting that indeed there is a connection between sprawl and public utility provision.

\section{Conclusions}

The literature on colonialism in Africa suggests that, compared to the British, the French imposed more comprehensive city wide land use planning, including the lay-out of roads. The theoretical literature in economics suggests that an omniscient and benevolent city planner would create a more compact city which encourages fluidity of movement than laissez faire development and that leapfrogging is related to intensity of centre city development. The empirical literature suggests that areas which through centralized control are more regularly laid out on a grid system will have higher levels of future development and/or land values. The African context of colonialism provides an experiment to show that choice of institutions which involve more centralized control within each city, as in Francophone compared to Anglophone cities, lead to more compact cities.

Specifically the paper shows that Francophone African cities have more grid-like structures

in their core areas. Anglophone cities have a city wide index of openness which is $22 \%$ higher. Their intensity of land use is $76 \%$ lower at the centre and, in contrast to Franco- 
phone cities, the intensity of land use gradient is almost flat. Anglophone cities are more sprawled. Correspondingly, with new development, Anglophone cities have about $70 \%$ more leapfrog patches, a number that is robust to a border experiment and many experiments with definitions and relevant cuts on the data in terms of samples. There is a consequence to having greater leapfrog development. Such areas are less likely to receive connections to public utilities, such as electricity, phone landlines, piped water, and city sewers.

\section{References}

Acemoglu, D., D. Cantoni, S. Johnson, and J. A. Robinson (2011, December). The consequences of radical reform: The french revolution. American Economic Review 101(7), $3286-3307$.

Acemoglu, D., S. Johnson, and J. A. Robinson (2000). The colonial origins of comparative development: An empirical investigation. Technical report, National bureau of economic research.

Ahmed, A. and R. D. Dinye (2011). Urbanisation and the challenges of development controls in ghana: A case study of wa township. Journal of Sustainable Development in Africa 13(7), 210-235.

Ban, Y., P. Gong, and C. Giri (2015). Global land cover mapping using earth observation satellite data: Recent progresses and challenges. ISPRS Journal of Photogrammetry and Remote Sensing 103, 1-6.

Banerjee, A. and L. Iyer (2005, September). History, Institutions, and Economic Performance: The Legacy of Colonial Land Tenure Systems in India. American Economic Review 95(4), 1190-1213.

Barton, H., M. Grant, and R. Guise (2003). Shaping neighbourhoods: a guide for health, sustainability and vitality. Taylor \& Francis. 
Bertrand, M. (2004). Land management and urban development projects: A comparison of experiences in french-speaking and english-speaking west africa. International Development Planning Review 26(1), 83-96.

Bleakley, H. and J. Lin (2012). Portage and path dependence. Quarterly Journal of Economics 127(2), 587-644.

Brooks, L. and B. Lutz (2014). Vestiges of transport: Urban persistence at a micro scale. GWU working paper.

Brueckner, J. K. (2001). Urban sprawl: Lessons from urban economics. Brookings-Wharton papers on urban affairs $2001(1), 65-97$.

Brueckner, J. K. (2005). Transport subsidies, system choice, and urban sprawl. Regional Science and Urban Economics 35(6), 715-733.

Burchfield, M., H. G. Overman, D. Puga, and M. A. Turner (2006). Causes of sprawl: A portrait from space. The Quarterly Journal of Economics 121(2), 587-633.

Burley, J. (2016). The built environment and social interactions: Evidence from panel data. Working papers, University of Toronto.

Calderón, F., J. Oppenheimer, and N. Stern (2014). Better growth, better climate-the new climate economy report-the synthesis report. Technical Report.

Crowder, M. (1964). Indirect rule - french and british style. Africa 34(03), 197-205.

Davis, O. A. and A. B. Whinston (1964). The economics of complex systems: The case of municipal zoning*. Kyklos 17(3), 419-446.

Donaldson, D. and A. Storeygard (2016, November). The view from above: Applications of satellite data in economics. Journal of Economic Perspectives 30(4), 171-98. 
Durand-Lasserve, A. (2004). Land for housing the poor in african cities: Are neo-customary processes an effective alternative to formal systems?'. http://siteresources.worldbank.org/INTURBANDEVELOPMENT/Resources/3363871268963780932/6881414-1268963797099/durand-lasserve.pdf.

Ellickson, R. C. (2012). The law and economics of street layouts: How a grid pattern benefits a downtown. Ala. L. Rev. 64, 463.

Epple, D. and T. Nechyba (2004). Fiscal decentralization. In J. V. Henderson and J. F. Thisse (Eds.), Handbook of Regional and Urban Economics (1 ed.), Volume 4, Chapter 55, pp. 2423-2480. Elsevier.

Giri, C., Z. Zhu, and B. Reed (2005). A comparative analysis of the global land cover 2000 and modis land cover data sets. Remote sensing of environment 94(1), 123-132.

Glaeser, E. L. and M. E. Kahn (2010, May). The greenness of cities: Carbon dioxide emissions and urban development. Journal of Urban Economics 67(3), 404-418.

Grant, R. and Y. Paul (2003). City profile: Accra. Journal Article - Cities 20(1), 65-74.

Guiso, L., P. Sapienza, and L. Zingales (2016). Long-term persistence. Journal of the European Economic Association 14(6), 1401-1436.

Harari, M. (2016). Cities in bad shape: Urban geometry in india. February. http://real. wharton. upenn. edu ${ }^{\sim}$ harari/Harari_Papers/CityShapeHarariMarch2016_updated. pdf .

Helsley, R. (2004). Urban political economics. In J. V. Henderson and J. F. Thisse (Eds.), Handbook of Regional and Urban Economics (1 ed.), Volume 4, Chapter 54, pp. 2381-2421. Elsevier.

Helsley, R. W. and W. C. Strange (2007). Urban interactions and spatial structure. Journal of Economic Geography 7(2), 119-138. 
Henderson, J. V., A. Storeygard, and D. N. Weil (2012, April). Measuring economic growth from outer space. American Economic Review 102(2), 994-1028.

Henderson, V. and A. Mitra (1996). The new urban landscape: Developers and edge cities. Regional Science and Urban Economics 26(6), 613-643.

Henderson, J. V., A. Storeygard, and U. Deichmann (2017). Has climate change driven urbanization in africa? Journal of Development Economics 124(C), 60-82.

Hochman, O., D. Pines, and J.-F. Thisse (1995). On the optimal structure of local governments. The American Economic Review 85(5), 1224-1240.

Home, R. (2015). Colonial urban planning in anglophone africa. In C. N. Silva (Ed.), Urban Planning in Sub-Saharan Africa: Colonial and Post-Colonial Planning Cultures, pp. 53-66. Routledge.

Hortas-Rico, M. and A. Solé-Ollé (2010). Does urban sprawl increase the costs of providing local public services? evidence from spanish municipalities. Urban studies.

La Porta, R., F. Lopez-de Silanes, C. Pop-Eleches, and A. Shleifer (2004). Judicial checks and balances. Journal of Political Economy 112(2), 445-470.

Lee, A. and K. A. Schultz (2012). Comparing british and french colonial legacies: A discontinuity analysis of cameroon. Quarterly Journal of Political Science 7(4), 365-410.

Libecap, G. D. and D. Lueck (2011). The demarcation of land and the role of coordinating property institutions. Journal of Political Economy 119(3), 426-467.

Liu, X., X. Li, Y. Chen, Z. Tan, S. Li, and B. Ai (2010). A new landscape index for quantifying urban expansion using multi-temporal remotely sensed data. Landscape Ecology 25(5), 671-682.

Njoh, A. J. (2015). French Urbanism in Foreign Lands. Springer. 
Nunn, N. and D. Puga (2012). Ruggedness: The blessing of bad geography in africa. The Review of Economics and Statistics 94(1), 20-36.

Oates, W. (1999). An essay on fiscal federalism. Journal of Economic Literature 37(3), 1120-1149.

O'Grady, T. (2014). Spatial institutions in urban economies: How city grids affect density and development. Harvard University.

Pesaresi, M., D. Ehrlich, S. Ferri, A. Florczyk, S. Freire, M. Halkia, A. Julea, T. Kemper, P. Soille, and V. Syrris (2016). Operating procedure for the production of the global human settlement layer from landsat data of the epochs 1975, 1990, 2000, and 2014. Technical report, JRC Technical Report.

Pesaresi, M., G. Huadong, X. Blaes, D. Ehrlich, S. Ferri, L. Gueguen, M. Halkia, M. Kauffmann, T. Kemper, L. Lu, et al. (2013). A global human settlement layer from optical hr/vhr rs data: concept and first results. IEEE Journal of Selected Topics in Applied Earth Observations and Remote Sensing 6(5), 2102-2131.

Putnam, R. (2000). Bowling alone, the collapse and revival of civic america. New York.

Redfearn, C. L. (2009). Persistence in urban form: The long-run durability of employment centers in metropolitan areas. Regional Science and Urban Economics 39(2), 224 - 232.

Rosin, P. L. (1999). Measuring rectangularity. Machine Vision and Applications 11(4), 191-196.

Rossi-Hansberg, E. (2004, January). Optimal land use and zoning. Review of Economic Dynamics 7, 69-106.

Saiz, A. (2010). The geographic determinants of housing supply. The Quarterly Journal of Economics 125(3), 1253-1296. 
Shertzer, A., T. Twinam, and R. P. Walsh (2016, July). Race, Ethnicity, and Discriminatory Zoning. American Economic Journal: Applied Economics 8(3), 217-246.

Trans-Africa Consortium (2010). Public transport in Sub-Saharan Africa: major trends and case studies. International Association of Public Transport (UITP), Brussels.

Trubka, R., P. Newman, and D. Bilsborough (2010). The costs of urban sprawl-infrastructure and transportation. ENVIRONMENT DESIGN GUIDE.

Turner, M. A. (2007). A simple theory of smart growth and sprawl. Journal of Urban Economics 61(1), 21-44.

Yinger, J. (1993, May). Around the Block: Urban Models with a Street Grid. Journal of Urban Economics 33(3), 305-330.

Žunić, D., C. Martinez-Ortiz, and J. Žunić (2012). Shape rectangularity measures. International Journal of Pattern Recognition and Artificial Intelligence 26(06), 1254002. 
Table 1: Openness and sprawl

\begin{tabular}{|c|c|c|c|c|c|c|}
\hline & \multicolumn{3}{|c|}{ Ln openness index 2014} & \multicolumn{3}{|c|}{ Ln ring built pixel } \\
\hline & $\begin{array}{l}\text { Base } \\
(1)\end{array}$ & $\begin{array}{l}\text { City controls } \\
\text { (2) }\end{array}$ & $\begin{array}{c}\text { Full controls } \\
\text { (3) }\end{array}$ & $\begin{array}{l}\text { Base } \\
(4)\end{array}$ & $\begin{array}{c}\text { City controls } \\
(5)\end{array}$ & $\begin{array}{c}\text { Full controls } \\
\text { (6) }\end{array}$ \\
\hline Anglophone country & $\begin{array}{c}0.229 * * * \\
(0.0455)\end{array}$ & $\begin{array}{c}0.192^{* * * *} \\
(0.0510)\end{array}$ & $\begin{array}{c}0.221^{* * * *} \\
(0.0523)\end{array}$ & $\begin{array}{c}-0.457^{* *} \\
(0.195)\end{array}$ & $\begin{array}{c}-0.687^{* * *} \\
(0.205)\end{array}$ & $\begin{array}{c}-0.755^{* * *} \\
(0.229)\end{array}$ \\
\hline Ring distance & & & & $\begin{array}{c}-0.0282^{* * *} \\
(0.00438)\end{array}$ & $\begin{array}{c}-0.0551^{* * *} \\
(0.00684)\end{array}$ & $\begin{array}{c}-0.0578 * * * \\
(0.00613)\end{array}$ \\
\hline Ring distance $\times$ Anglophone & & & & $\begin{array}{l}0.0132^{* *} \\
(0.00556)\end{array}$ & $\begin{array}{c}0.0438^{* * *} \\
(0.0107)\end{array}$ & $\begin{array}{c}0.0481^{* * *} \\
(0.0118)\end{array}$ \\
\hline Ln ring total pixel & & & & $\begin{array}{c}0.895^{* * *} \\
(0.0866)\end{array}$ & $\begin{array}{c}0.701^{* * *} \\
(0.0426)\end{array}$ & $\begin{array}{l}0.699^{* * *} \\
(0.0431)\end{array}$ \\
\hline Ln income per capita 1990 & & $\begin{array}{c}0.0423 \\
(0.0435)\end{array}$ & $\begin{array}{c}0.0632 \\
(0.0444)\end{array}$ & & $\begin{array}{l}-0.169 \\
(0.154)\end{array}$ & $\begin{array}{l}-0.213 \\
(0.166)\end{array}$ \\
\hline Ln projected city population 1990 & & $\begin{array}{c}-0.175^{* * *} \\
(0.0210)\end{array}$ & $\begin{array}{c}-0.158^{* * *} \\
(0.0216)\end{array}$ & & $\begin{array}{c}0.510^{* * * *} \\
(0.0762)\end{array}$ & $\begin{array}{c}0.496^{* * * *} \\
(0.0827)\end{array}$ \\
\hline Ln country light growth 92 to 12 excluding own city & & $\begin{array}{l}-0.0328 \\
(0.0531)\end{array}$ & $\begin{array}{l}0.00101 \\
(0.0518)\end{array}$ & & $\begin{array}{l}0.0142 \\
(0.162)\end{array}$ & $\begin{array}{c}-0.0311 \\
(0.169)\end{array}$ \\
\hline Ln ruggedness & & $\begin{array}{c}-0.00320 \\
(0.0213)\end{array}$ & $\begin{array}{l}-0.00865 \\
(0.0213)\end{array}$ & & $\begin{array}{c}0.0228 \\
(0.0773)\end{array}$ & $\begin{array}{l}0.00501 \\
(0.0753)\end{array}$ \\
\hline Ln rainfall & & $\begin{array}{c}-0.123^{* * *} \\
(0.0383)\end{array}$ & $\begin{array}{c}-0.134^{* * *} \\
(0.0506)\end{array}$ & & $\begin{array}{c}0.564^{* * *} \\
(0.202)\end{array}$ & $\begin{array}{c}0.299 \\
(0.188)\end{array}$ \\
\hline Ln elevation range & & $\begin{array}{c}0.131^{* * *} \\
(0.0323)\end{array}$ & $\begin{array}{l}0.108^{* * * *} \\
(0.0331)\end{array}$ & & $\begin{array}{r}-0.0630 \\
(0.144)\end{array}$ & $\begin{array}{c}-0.00827 \\
(0.128)\end{array}$ \\
\hline Coast dummy & & $\begin{array}{c}0.131 \\
(1.229)\end{array}$ & $\begin{array}{c}0.987 \\
(1.290)\end{array}$ & & $\begin{array}{c}0.107 \\
(3.130)\end{array}$ & $\begin{array}{l}-1.178 \\
(3.301)\end{array}$ \\
\hline Ln coast length $\times$ coast dummy & & $\begin{array}{c}-0.0454 \\
(0.101)\end{array}$ & $\begin{array}{c}-0.0900 \\
(0.106)\end{array}$ & & $\begin{array}{c}0.177 \\
(0.353)\end{array}$ & $\begin{array}{c}0.211 \\
(0.306)\end{array}$ \\
\hline Ln distance to coast $\times$ coast dummy & & $\begin{array}{c}0.0363 \\
(0.0708)\end{array}$ & $\begin{array}{l}-0.0190 \\
(0.0692)\end{array}$ & & $\begin{array}{l}-0.181 \\
(0.151)\end{array}$ & $\begin{array}{r}-0.0660 \\
(0.170)\end{array}$ \\
\hline Fraction of river area & & $\begin{array}{l}0.0622 \\
(0.609)\end{array}$ & $\begin{array}{l}0.0346 \\
(0.608)\end{array}$ & & $\begin{array}{c}0.832 \\
(2.867)\end{array}$ & $\begin{array}{c}0.646 \\
(2.629)\end{array}$ \\
\hline Fraction of lake area & & $\begin{array}{l}-0.651 \\
(1.007)\end{array}$ & $\begin{array}{l}-0.154 \\
(0.966)\end{array}$ & & $\begin{array}{l}-0.156 \\
(3.052)\end{array}$ & $\begin{array}{l}-0.725 \\
(3.187)\end{array}$ \\
\hline Fraction of forest & & & $\begin{array}{c}0.241^{* *} \\
(0.107)\end{array}$ & & & $\begin{array}{c}0.00880 \\
(0.383)\end{array}$ \\
\hline Fraction of shrubs & & & $\begin{array}{l}0.229^{* *} \\
(0.0966)\end{array}$ & & & $\begin{array}{r}-0.0547 \\
(0.330)\end{array}$ \\
\hline Fraction of crops & & & $\begin{array}{c}0.0461 \\
(0.0873)\end{array}$ & & & $\begin{array}{c}0.252 \\
(0.316)\end{array}$ \\
\hline Fraction of wetlands and water & & & $\begin{array}{l}-0.609 \\
(0.415)\end{array}$ & & & $\begin{array}{l}2.792^{* *} \\
(1.354)\end{array}$ \\
\hline Fraction of sparse vege and bare land & & & $\begin{array}{c}0.215 \\
(0.150)\end{array}$ & & & $\begin{array}{l}-1.133^{*} \\
(0.654)\end{array}$ \\
\hline Observations & 307 & 307 & 307 & 4,875 & 4,875 & 4,875 \\
\hline R-squared & 0.080 & 0.304 & 0.343 & 0.193 & 0.326 & 0.333 \\
\hline
\end{tabular}

Notes: Robust standard errors in parentheses for openness index; Standard errors are clustered at city level in column 4-6. ${ }^{* * *} \mathrm{p}<0.01,{ }^{* *} \mathrm{p}<0.05,{ }^{*} \mathrm{p}<0.1$ 
Table 2: Intensification and convergence

\begin{tabular}{|c|c|c|c|c|}
\hline & \multicolumn{2}{|c|}{ Ln openness index growth 90-14 } & \multicolumn{2}{|c|}{ Long difference of $\ln$ ring built pixel } \\
\hline & $\begin{array}{l}\text { Full controls } \\
\text { (1) }\end{array}$ & $\begin{array}{c}\text { Add openness index } 1990 \\
(2)\end{array}$ & $\begin{array}{l}\text { Full controls } \\
\text { (3) }\end{array}$ & $\begin{array}{l}\text { Add built cover } 1990 \\
\text { (4) }\end{array}$ \\
\hline Anglophone country & $\begin{array}{c}-0.0472^{* *} \\
(0.0237)\end{array}$ & $\begin{array}{l}-0.0328 \\
(0.0278)\end{array}$ & $\begin{array}{c}0.262^{* * *} \\
(0.0847)\end{array}$ & $\begin{array}{c}0.0589 \\
(0.0878)\end{array}$ \\
\hline Ln openness index 1990 & & $\begin{array}{l}-0.0537 \\
(0.0400)\end{array}$ & & \\
\hline Ring distance & & & $\begin{array}{c}0.00768^{* * *} \\
(0.00180)\end{array}$ & $\begin{array}{c}-0.00849^{* * *} \\
(0.00219)\end{array}$ \\
\hline Ring distance $\times$ Anglophone & & & $\begin{array}{l}-0.00217 \\
(0.00221)\end{array}$ & $\begin{array}{c}0.00990^{* * *} \\
(0.00293)\end{array}$ \\
\hline Ln ring total pixel & & & $\begin{array}{l}0.181^{* * *} \\
(0.0271)\end{array}$ & $\begin{array}{l}0.268^{* * *} \\
(0.0252)\end{array}$ \\
\hline Ln ring built cover in 1990 & & & & $\begin{array}{c}-0.261^{* * *} \\
(0.0175)\end{array}$ \\
\hline Geographic controls & Yes & Yes & Yes & Yes \\
\hline Observations & 307 & 307 & 4,499 & 4,499 \\
\hline R-squared & 0.066 & 0.076 & 0.102 & 0.427 \\
\hline
\end{tabular}

Notes: Geographic controls include log ruggedness, log rainfall, log elevation range, coast dummy, interaction of log coast length with Anglophone dummy, interaction of log distance to coast with Anglophone dummy, fraction of river area, fraction of lake area, fraction of forest, fraction of shrubs, fraction of crops, fraction of wetlands and water, fraction of sparse vegetables and bare land. Other control variables include log income per capita 1990, log projected city population 1990, log country light growth 1992 to 2012 excluding the city itself. Robust standard errors in parentheses for openness index; Standard errors are clustered at city level in column 3 and 4. *** $\mathrm{p}<0.01, * * \mathrm{p}<0.05, * \mathrm{p}<0.1$ 
Table 3: Intensity by rings in 1990

\begin{tabular}{lcccccc}
\hline & $<1 \mathrm{~km}$ & $1-2 \mathrm{~km}$ & $2-3 \mathrm{~km}$ & $3-4 \mathrm{~km}$ & $4-5 \mathrm{~km}$ & $5-6 \mathrm{~km}$ \\
\hline \multirow{2}{*}{ Anglophone country } & $-0.373^{* *}$ & $-0.618^{* * *}$ & $-0.784^{* * *}$ & $-0.760^{* * *}$ & -0.304 & 0.0351 \\
& $(0.154)$ & $(0.167)$ & $(0.192)$ & $(0.223)$ & $(0.240)$ & $(0.264)$ \\
Ln ring total pixel & $1.075^{* * *}$ & 0.521 & -0.0871 & 0.205 & $0.499^{* * *}$ & $0.412^{* * *}$ \\
& $(0.351)$ & $(0.461)$ & $(0.208)$ & $(0.156)$ & $(0.168)$ & $(0.142)$ \\
& & & & & & \\
Geographic controls & Yes & Yes & Yes & Yes & Yes & Yes \\
Observations & 312 & 316 & 307 & 283 & 254 & 218 \\
R-squared & 0.252 & 0.325 & 0.417 & 0.502 & 0.531 & 0.469 \\
& & & & & \\
& $6-7 \mathrm{~km}$ & $7-8 \mathrm{~km}$ & $8-9 \mathrm{~km}$ & $9-10 \mathrm{~km}$ & $10-11 \mathrm{~km}$ & $11-12 \mathrm{~km}$ \\
\hline \multirow{2}{*}{ Anglophone country } & -0.391 & -0.282 & -0.294 & -0.301 & -0.262 & 0.272 \\
& $(0.316)$ & $(0.320)$ & $(0.349)$ & $(0.367)$ & $(0.322)$ & $(0.375)$ \\
Ln ring total pixel & $0.689^{* * *}$ & $0.586^{* * *}$ & $0.620^{* * *}$ & $0.445^{* *}$ & $0.628^{* * *}$ & $0.460^{* *}$ \\
& $(0.261)$ & $(0.218)$ & $(0.207)$ & $(0.205)$ & $(0.169)$ & $(0.202)$ \\
Geographic controls & Yes & Yes & Yes & Yes & Yes & Yes \\
Observations & 199 & 169 & 160 & 146 & 133 & 122 \\
R-squared & 0.491 & 0.575 & 0.499 & 0.482 & 0.518 & 0.513 \\
\hline
\end{tabular}

Notes: Geographic controls include log ruggedness, log rainfall, log elevation range, coast dummy, interaction of log coast length with Anglophone dummy, interaction of log distance to coast with Anglophone dummy, fraction of river area, fraction of lake area, fraction of forest, fraction of shrubs, fraction of crops, fraction of wetlands and water, fraction of sparse vegetables and bare land. Other city characteristics control variables include log income per capita 1990, log projected city population 1990. Columns 5-8 add the control of log country light growth 1992 to 2012 excluding the city itself. Robust standard errors in parentheses for openness index; Standard errors are clustered at city level.

$* * * \mathrm{p}<0.01,{ }^{*} * \mathrm{p}<0.05, * \mathrm{p}<0.1$ 
Table 4: Intensification by rings

\begin{tabular}{|c|c|c|c|c|c|c|c|c|}
\hline & \multicolumn{4}{|c|}{ Full controls } & \multicolumn{4}{|c|}{ Add built cover 1990} \\
\hline & $\begin{array}{c}<1 \mathrm{~km} \\
(1)\end{array}$ & $\begin{array}{l}1-2 \mathrm{~km} \\
(2)\end{array}$ & $\begin{array}{c}2-3 \mathrm{~km} \\
(3)\end{array}$ & $\begin{array}{c}3-4 \mathrm{~km} \\
(4)\end{array}$ & $\begin{array}{c}¡ 1 \mathrm{~km} \\
(5)\end{array}$ & $\begin{array}{c}1-2 \mathrm{~km} \\
(6)\end{array}$ & $\begin{array}{c}2-3 \mathrm{~km} \\
(7)\end{array}$ & $\begin{array}{c}3-4 \mathrm{~km} \\
(8)\end{array}$ \\
\hline Anglophone country & $\begin{array}{c}0.249^{* *} \\
(0.110)\end{array}$ & $\begin{array}{c}0.370^{* * *} \\
(0.0790)\end{array}$ & $\begin{array}{c}0.442^{* * *} \\
(0.112)\end{array}$ & $\begin{array}{c}0.372^{* * *} \\
(0.129)\end{array}$ & $\begin{array}{c}1.134 \\
(1.611)\end{array}$ & $\begin{array}{l}1.474^{*} \\
(0.870)\end{array}$ & $\begin{array}{c}1.473 \\
(0.920)\end{array}$ & $\begin{array}{c}0.716 \\
(0.729)\end{array}$ \\
\hline Ln ring total pixel & $\begin{array}{c}-0.569^{*} \\
(0.321)\end{array}$ & $\begin{array}{l}0.0340 \\
(0.125)\end{array}$ & $\begin{array}{c}0.268^{* * *} \\
(0.0941)\end{array}$ & $\begin{array}{c}0.208^{* * *} \\
(0.0779)\end{array}$ & $\begin{array}{c}0.196 \\
(0.154)\end{array}$ & $\begin{array}{c}0.471^{* * *} \\
(0.132)\end{array}$ & $\begin{array}{c}0.450^{* * *} \\
(0.0948)\end{array}$ & $\begin{array}{c}0.341 * * * \\
(0.0711)\end{array}$ \\
\hline Ln ring built cover in 1990 & & & & & $\begin{array}{c}-0.360^{* * *} * \\
(0.111)\end{array}$ & $\begin{array}{c}-0.198^{* * *} * \\
(0.0523)\end{array}$ & $\begin{array}{c}-0.236^{* * *} * \\
(0.0653)\end{array}$ & $\begin{array}{c}-0.252^{* * *} \\
(0.0519)\end{array}$ \\
\hline Ln ring built cover in $1990 \times$ Anglophone & & & & & $\begin{array}{r}-0.0765 \\
(0.112)\end{array}$ & $\begin{array}{l}-0.0924 \\
(0.0586)\end{array}$ & $\begin{array}{l}-0.0979 \\
(0.0624)\end{array}$ & $\begin{array}{l}-0.0467 \\
(0.0515)\end{array}$ \\
\hline Geographic controls & Yes & Yes & Yes & Yes & Yes & Yes & Yes & Yes \\
\hline Observations & 312 & 316 & 307 & 283 & 312 & 316 & 307 & 283 \\
\hline R-squared & 0.157 & 0.212 & 0.256 & 0.229 & 0.655 & 0.536 & 0.565 & 0.454 \\
\hline
\end{tabular}

Notes: Geographic controls include log ruggedness, log rainfall, log elevation range, coast dummy, interaction of log coast length with Anglophone dummy, interaction of log distance to coast with Anglophone dummy, fraction of river area, fraction of lake area, fraction of forest, fraction of shrubs, fraction of crops, fraction of wetlands and water, fraction of sparse vegetables and bare land. Other city characteristics control variables include log income per capita 1990, log projected city population 1990, log country light growth 1992 to 2012 excluding the city itself. Robust standard errors in parentheses for openness index; Standard errors are clustered at city level. $* * * \mathrm{p}<0.01,{ }^{* *} \mathrm{p}<0.05,{ }^{*} \mathrm{p}<0.1$ 
Table 5: Leapfrogging

\begin{tabular}{|c|c|c|c|c|c|c|}
\hline & \multicolumn{2}{|c|}{ Ln count of LF } & \multicolumn{2}{|c|}{ Ln LF minus ln total patches } & \multicolumn{2}{|c|}{ Ln avg. LF area } \\
\hline & $\begin{array}{l}\text { Base } \\
(1)\end{array}$ & $\begin{array}{l}\text { Full controls } \\
(2)\end{array}$ & $\begin{array}{c}\text { Base } \\
(3)\end{array}$ & $\begin{array}{l}\text { Full controls } \\
\text { (4) }\end{array}$ & $\begin{array}{l}\text { Base } \\
(5)\end{array}$ & $\begin{array}{l}\text { Full controls } \\
(6)\end{array}$ \\
\hline Anglophone country & $\begin{array}{c}0.907^{* * *} \\
(0.155)\end{array}$ & $\begin{array}{c}0.720^{* * *} \\
(0.147)\end{array}$ & $\begin{array}{c}0.339 * * * \\
(0.109)\end{array}$ & $\begin{array}{c}0.274^{* *} \\
(0.110)\end{array}$ & $\begin{array}{c}0.0345 \\
(0.0512)\end{array}$ & $\begin{array}{c}0.0166 \\
(0.0616)\end{array}$ \\
\hline Ln initial built cover 1990 & $\begin{array}{l}0.656^{* * *} \\
(0.0337)\end{array}$ & $\begin{array}{l}0.332^{* * * *} \\
(0.0432)\end{array}$ & $\begin{array}{c}-0.0812^{* * * *} \\
(0.0252)\end{array}$ & $\begin{array}{c}-0.290^{* * *} \\
(0.0260)\end{array}$ & $\begin{array}{c}0.0645^{* * *} \\
(0.00909)\end{array}$ & $\begin{array}{c}0.0318 \\
(0.0193)\end{array}$ \\
\hline Year dummy 2014 & $\begin{array}{c}0.517^{* * *} \\
(0.170)\end{array}$ & $\begin{array}{c}0.471^{* * *} \\
(0.100)\end{array}$ & $\begin{array}{c}0.119 \\
(0.0947)\end{array}$ & $\begin{array}{c}0.112^{*} \\
(0.0630)\end{array}$ & $\begin{array}{l}0.145^{* * *} \\
(0.0476)\end{array}$ & $\begin{array}{l}0.145^{* * *} \\
(0.0391)\end{array}$ \\
\hline Ln income per capita t-1 & & $\begin{array}{c}0.219 \\
(0.149)\end{array}$ & & $\begin{array}{l}-0.0215 \\
(0.0895)\end{array}$ & & $\begin{array}{l}-0.00329 \\
(0.0447)\end{array}$ \\
\hline Ln projected city population 1990 & & $\begin{array}{l}0.649^{* * *} \\
(0.0807)\end{array}$ & & $\begin{array}{c}0.410^{* * *} \\
(0.0429)\end{array}$ & & $\begin{array}{c}0.0278 \\
(0.0426)\end{array}$ \\
\hline Ln country light growth excluding own city & & $\begin{array}{c}0.620^{* * *} \\
(0.170)\end{array}$ & & $\begin{array}{c}0.402^{* * *} \\
(0.0901)\end{array}$ & & $\begin{array}{l}0.148^{* *} \\
(0.0608)\end{array}$ \\
\hline Ln ruggedness & & $\begin{array}{l}-0.0154 \\
(0.0568)\end{array}$ & & $\begin{array}{c}-0.103^{* * *} \\
(0.0339)\end{array}$ & & $\begin{array}{l}-0.0137 \\
(0.0205)\end{array}$ \\
\hline Ln rainfall & & $\begin{array}{c}-0.350^{* * *} \\
(0.105)\end{array}$ & & $\begin{array}{l}-0.189^{* *} \\
(0.0710)\end{array}$ & & $\begin{array}{l}-0.0576 \\
(0.0542)\end{array}$ \\
\hline Ln elevation range & & $\begin{array}{c}0.472^{* * *} \\
(0.0674)\end{array}$ & & $\begin{array}{c}0.251^{* * *} \\
(0.0460)\end{array}$ & & $\begin{array}{c}0.127^{* * *} \\
(0.0277)\end{array}$ \\
\hline Coast dummy & & $\begin{array}{c}-7.018^{* *} \\
(2.743)\end{array}$ & & $\begin{array}{c}-8.029^{* * *} \\
(1.848)\end{array}$ & & $\begin{array}{c}-2.813^{* * *} \\
(0.857)\end{array}$ \\
\hline Ln coast length $\times$ coast dummy & & $\begin{array}{l}0.462^{*} \\
(0.263)\end{array}$ & & $\begin{array}{c}0.499^{* * *} \\
(0.159)\end{array}$ & & $\begin{array}{l}0.191^{* *} \\
(0.0832)\end{array}$ \\
\hline Ln distance to coast $\times$ coast dummy & & $\begin{array}{c}0.222 \\
(0.146)\end{array}$ & & $\begin{array}{c}0.316^{* *} \\
(0.129)\end{array}$ & & $\begin{array}{c}0.0917 \\
(0.0603)\end{array}$ \\
\hline Fraction of river area & & $\begin{array}{c}1.000 \\
(1.818)\end{array}$ & & $\begin{array}{l}-0.167 \\
(1.041)\end{array}$ & & $\begin{array}{l}-0.862 \\
(0.570)\end{array}$ \\
\hline Fraction of lake area & & $\begin{array}{c}-2.905^{* *} \\
(1.394)\end{array}$ & & $\begin{array}{c}-2.929^{* *} \\
(1.330)\end{array}$ & & $\begin{array}{l}-1.290^{*} \\
(0.743)\end{array}$ \\
\hline Fraction of forest & & $\begin{array}{c}0.00145 \\
(0.256)\end{array}$ & & $\begin{array}{l}-0.202 \\
(0.159)\end{array}$ & & $\begin{array}{l}-0.116 \\
(0.113)\end{array}$ \\
\hline Fraction of shrubs & & $\begin{array}{c}0.566^{* *} \\
(0.233)\end{array}$ & & $\begin{array}{c}0.168 \\
(0.124)\end{array}$ & & $\begin{array}{c}-0.118 \\
(0.0755)\end{array}$ \\
\hline Fraction of crops & & $\begin{array}{l}-0.0164 \\
(0.219)\end{array}$ & & $\begin{array}{l}-0.122 \\
(0.149)\end{array}$ & & $\begin{array}{c}-0.0148 \\
(0.117)\end{array}$ \\
\hline Fraction of wetlands and water & & $\begin{array}{c}0.908 \\
(0.908)\end{array}$ & & $\begin{array}{l}1.138^{*} \\
(0.590)\end{array}$ & & $\begin{array}{c}0.171 \\
(0.355)\end{array}$ \\
\hline Fraction of sparse vege and bare land & & $\begin{array}{c}-1.637^{* * *} \\
(0.386)\end{array}$ & & $\begin{array}{c}-1.305^{* * *} \\
(0.308)\end{array}$ & & $\begin{array}{c}-0.445^{* *} \\
(0.173)\end{array}$ \\
\hline Observations & 606 & 606 & 606 & 606 & 578 & 578 \\
\hline R-squared & 0.448 & 0.594 & 0.058 & 0.239 & 0.078 & 0.151 \\
\hline
\end{tabular}

Notes: Standard errors are clustered at country year level *** $\mathrm{p}<0.01,{ }^{*} * \mathrm{p}<0.05, * \mathrm{p}<0.1$ 
Table 6: Border regression discontinuity $100 \mathrm{~km}$

\begin{tabular}{|c|c|c|c|c|}
\hline & \multicolumn{2}{|c|}{ With Anglophone Cameroon } & \multicolumn{2}{|c|}{ Without Anglophone Cameroon } \\
\hline & $\begin{array}{l}\text { Full controls } \\
\text { (1) }\end{array}$ & $\begin{array}{c}\text { City cluster FE } \\
(2)\end{array}$ & $\begin{array}{c}\text { Full controls } \\
(3)\end{array}$ & City cluster FE \\
\hline Anglophone country: Ln count of LF & $\begin{array}{c}0.887^{* * *} \\
(0.299)\end{array}$ & $\begin{array}{c}0.674^{* *} \\
(0.321)\end{array}$ & $\begin{array}{c}1.092^{* * *} \\
(0.325)\end{array}$ & $\begin{array}{c}0.856^{* *} \\
(0.356)\end{array}$ \\
\hline Anglophone country: Ln LF minus ln total patches & $\begin{array}{c}0.442^{*} \\
(0.238)\end{array}$ & $\begin{array}{c}0.282 \\
(0.249)\end{array}$ & $\begin{array}{c}0.575^{* *} \\
(0.265)\end{array}$ & $\begin{array}{c}0.449 \\
(0.288)\end{array}$ \\
\hline Anglophone country: Ln avg. of LF area & $\begin{array}{l}-0.259 \\
(0.200)\end{array}$ & $\begin{array}{l}-0.123 \\
(0.171)\end{array}$ & $\begin{array}{l}-0.235 \\
(0.222)\end{array}$ & $\begin{array}{l}-0.157 \\
(0.201)\end{array}$ \\
\hline $\mathrm{N}$ (counts) & 131 & 121 & 113 & 107 \\
\hline
\end{tabular}

Notes: Standard errors are clustered at city year level *** $\mathrm{p}<0.01,{ }^{*} * \mathrm{p}<0.05,{ }^{*} \mathrm{p}<0.1$ 
Table 7: Leapfrogging: Robustness

\begin{tabular}{|c|c|c|c|c|c|c|c|c|}
\hline & $\begin{array}{c}\text { Base case } \\
\text { (1) }\end{array}$ & $\begin{array}{l}\text { No single pixel } \\
\text { LF patches } \\
(2)\end{array}$ & $\begin{array}{c}60 \mathrm{~m} \text { buffer } \\
\text { rather than } 300 \\
(3)\end{array}$ & $\begin{array}{l}\text { Trim } \\
(4)\end{array}$ & $\begin{array}{c}\text { No German } \\
\text { (5) }\end{array}$ & $\begin{array}{c}\text { No Nigeria } \\
\text { (6) }\end{array}$ & $\begin{array}{l}\text { Colonial cities strict } \\
\qquad(7)\end{array}$ & $\begin{array}{l}40 \text { Cities } \\
\text { (8) }\end{array}$ \\
\hline Anglophone country: Ln count of LF & $\begin{array}{c}0.720^{* * *} \\
(0.147)\end{array}$ & $\begin{array}{c}0.673^{* * *} \\
(0.169)\end{array}$ & $\begin{array}{c}0.694^{* * *} \\
(0.107)\end{array}$ & $\begin{array}{c}0.661^{* * *} \\
(0.163)\end{array}$ & $\begin{array}{c}0.640^{* * *} \\
(0.127)\end{array}$ & $\begin{array}{c}0.746^{* * *} \\
(0.193)\end{array}$ & $\begin{array}{c}2.666^{* * *} \\
(0.650)\end{array}$ & $\begin{array}{c}1.153^{* * *} * \\
(0.273)\end{array}$ \\
\hline Anglophone country: Ln LF minus ln total patches & $\begin{array}{c}0.274^{* *} \\
(0.110)\end{array}$ & $\begin{array}{c}0.196 \\
(0.133)\end{array}$ & $\begin{array}{c}0.248^{* * *} \\
(0.0620)\end{array}$ & $\begin{array}{c}0.316^{* *} \\
(0.127)\end{array}$ & $\begin{array}{c}0.184^{* *} \\
(0.0753)\end{array}$ & $\begin{array}{l}0.260^{*} \\
(0.149)\end{array}$ & $\begin{array}{c}0.992^{*} \\
(0.568)\end{array}$ & $\begin{array}{c}0.342 \\
(0.284)\end{array}$ \\
\hline Anglophone country: Ln avg. of LF area & $\begin{array}{c}0.0166 \\
(0.0616)\end{array}$ & $\begin{array}{c}0.0138 \\
(0.0522)\end{array}$ & $\begin{array}{r}-0.00184 \\
(0.0482)\end{array}$ & $\begin{array}{c}0.0514 \\
(0.0570)\end{array}$ & $\begin{array}{r}-0.00920 \\
(0.0572)\end{array}$ & $\begin{array}{c}-0.0350 \\
(0.0630)\end{array}$ & $\begin{array}{c}0.235 \\
(0.349)\end{array}$ & $\begin{array}{c}0.179 \\
(0.161)\end{array}$ \\
\hline $\mathrm{N}$ (counts) & 606 & 606 & 606 & 545 & 544 & 377 & 69 & 58 \\
\hline
\end{tabular}

Notes: Standard errors are clustered at country year level

$* * * \mathrm{p}<0.01,{ }^{* *} \mathrm{p}<0.05,{ }^{*} \mathrm{p}<0.1$ 
Table 8: Public utility connection

\begin{tabular}{|c|c|c|c|c|c|c|c|c|}
\hline & \multicolumn{2}{|c|}{ Has electricity } & \multicolumn{2}{|c|}{ Has phone land line } & \multicolumn{2}{|c|}{ Has piped water } & \multicolumn{2}{|c|}{ Has flush toilet } \\
\hline & $\begin{array}{l}\text { Base } \\
(1)\end{array}$ & $\begin{array}{l}\text { Full controls } \\
\text { (2) }\end{array}$ & $\begin{array}{l}\text { Base } \\
(3)\end{array}$ & $\begin{array}{l}\text { Full controls } \\
\text { (4) }\end{array}$ & $\begin{array}{l}\text { Base } \\
(5)\end{array}$ & $\begin{array}{c}\text { Full controls } \\
\text { (6) }\end{array}$ & $\begin{array}{l}\text { Base } \\
(7)\end{array}$ & $\begin{array}{c}\text { Full controls } \\
\text { (8) }\end{array}$ \\
\hline Count of LF & $\begin{array}{c}-0.00879 * * * \\
(0.00243)\end{array}$ & $\begin{array}{c}-0.00936^{* * *} \\
(0.00221)\end{array}$ & $\begin{array}{c}-0.00353^{* * *} \\
(0.00114)\end{array}$ & $\begin{array}{c}-0.00376^{* * *} \\
(0.00111)\end{array}$ & $\begin{array}{l}-0.00405^{*} \\
(0.00235)\end{array}$ & $\begin{array}{l}-0.00416^{*} \\
(0.00235)\end{array}$ & $\begin{array}{l}-0.00110 \\
(0.00200)\end{array}$ & $\begin{array}{l}-0.00148 \\
(0.00185)\end{array}$ \\
\hline Dummy has LF & $\begin{array}{c}-0.0452^{*} \\
(0.0254)\end{array}$ & $\begin{array}{c}-0.0396^{*} \\
(0.0240)\end{array}$ & $\begin{array}{c}0.00765 \\
(0.00967)\end{array}$ & $\begin{array}{c}0.00970 \\
(0.00944)\end{array}$ & $\begin{array}{c}0.000174 \\
(0.0255)\end{array}$ & $\begin{array}{l}0.00111 \\
(0.0261)\end{array}$ & $\begin{array}{c}-0.00735 \\
(0.0213)\end{array}$ & $\begin{array}{c}-0.00579 \\
(0.0203)\end{array}$ \\
\hline Share of built cover & $\begin{array}{l}-0.0441 \\
(0.0487)\end{array}$ & $\begin{array}{l}-0.0516 \\
(0.0451)\end{array}$ & $\begin{array}{c}0.0174 \\
(0.0169)\end{array}$ & $\begin{array}{c}0.0131 \\
(0.0165)\end{array}$ & $\begin{array}{c}0.0142 \\
(0.0634)\end{array}$ & $\begin{array}{l}0.00682 \\
(0.0637)\end{array}$ & $\begin{array}{c}0.130^{* * *} \\
(0.0431)\end{array}$ & $\begin{array}{c}0.120^{* * *} \\
(0.0406)\end{array}$ \\
\hline Ln buffer center distance & $\begin{array}{c}-0.0672^{* * *} \\
(0.0126)\end{array}$ & $\begin{array}{c}-0.0578 * * * \\
(0.0118)\end{array}$ & $\begin{array}{l}-0.0118^{* *} \\
(0.00479)\end{array}$ & $\begin{array}{c}-0.00960^{* *} \\
(0.00478)\end{array}$ & $\begin{array}{c}-0.0469 * * * \\
(0.0163)\end{array}$ & $\begin{array}{c}-0.0476^{* * *} \\
(0.0167)\end{array}$ & $\begin{array}{l}-0.0129 \\
(0.0107)\end{array}$ & $\begin{array}{c}-0.00882 \\
(0.0103)\end{array}$ \\
\hline Ln buffer ruggedness & $\begin{array}{l}0.0553^{* *} \\
(0.0255)\end{array}$ & $\begin{array}{c}0.0540 * * \\
(0.0240)\end{array}$ & $\begin{array}{c}0.00166 \\
(0.00464)\end{array}$ & $\begin{array}{c}0.00186 \\
(0.00461)\end{array}$ & $\begin{array}{c}0.0716^{* *} \\
(0.0336)\end{array}$ & $\begin{array}{c}0.0709 * * \\
(0.0338)\end{array}$ & $\begin{array}{l}0.00573 \\
(0.0126)\end{array}$ & $\begin{array}{l}0.00529 \\
(0.0126)\end{array}$ \\
\hline Buffer has river of lake & $\begin{array}{l}-0.00846 \\
(0.0414)\end{array}$ & $\begin{array}{c}-0.000738 \\
(0.0379)\end{array}$ & $\begin{array}{c}-0.0433^{* * *} \\
(0.0147)\end{array}$ & $\begin{array}{c}-0.0392^{* * *} \\
(0.0151)\end{array}$ & $\begin{array}{c}0.0859 \\
(0.0593)\end{array}$ & $\begin{array}{c}0.0865 \\
(0.0594)\end{array}$ & $\begin{array}{c}0.0149 \\
(0.0393)\end{array}$ & $\begin{array}{c}0.0234 \\
(0.0368)\end{array}$ \\
\hline Household size & & $\begin{array}{c}0.00785^{* * *} \\
(0.000972)\end{array}$ & & $\begin{array}{c}0.00437^{* * * *} \\
(0.000734)\end{array}$ & & $\begin{array}{c}0.00150 \\
(0.000968)\end{array}$ & & $\begin{array}{c}0.00317^{* * *} \\
(0.000749)\end{array}$ \\
\hline Sex of household head: Male & & $\begin{array}{l}-0.00475 \\
(0.00718)\end{array}$ & & $\begin{array}{l}-0.00434 \\
(0.00359)\end{array}$ & & $\begin{array}{l}-0.00376 \\
(0.00699)\end{array}$ & & $\begin{array}{c}-0.0174 * * * \\
(0.00614)\end{array}$ \\
\hline Highest educational level of head: Primary & & $\begin{array}{c}0.0385^{* * * *} \\
(0.0110)\end{array}$ & & $\begin{array}{l}-0.00346 \\
(0.00444)\end{array}$ & & $\begin{array}{l}0.00882 \\
(0.0108)\end{array}$ & & $\begin{array}{c}-0.0323^{* * *} \\
(0.00672)\end{array}$ \\
\hline Highest educational level of head: Secondary & & $\begin{array}{l}0.145^{* * *} \\
(0.0102)\end{array}$ & & $\begin{array}{l}0.0135 * * * \\
(0.00441)\end{array}$ & & $\begin{array}{c}0.0247^{* *} \\
(0.0101)\end{array}$ & & $\begin{array}{l}0.0166^{* * * *} \\
(0.00570)\end{array}$ \\
\hline Highest educational level of head: Higher & & $\begin{array}{c}0.257^{* * *} \\
(0.0126)\end{array}$ & & $\begin{array}{l}0.0701^{* * *} \\
(0.00693)\end{array}$ & & $\begin{array}{c}0.0357 * * * \\
(0.0137)\end{array}$ & & $\begin{array}{c}0.141^{* * *} \\
(0.0115)\end{array}$ \\
\hline Highest educational level of head: Don't know & & $\begin{array}{c}0.189^{*} \\
(0.0989)\end{array}$ & & $\begin{array}{c}0.101 \\
(0.124)\end{array}$ & & $\begin{array}{l}-0.0387 \\
(0.0737)\end{array}$ & & $\begin{array}{l}0.0214 \\
(0.110)\end{array}$ \\
\hline Mean & 0.764 & 0.764 & 0.0526 & 0.0526 & 0.499 & 0.499 & 0.140 & 0.140 \\
\hline Observations & 20,985 & 20,306 & 20,658 & 19,979 & 21,016 & 20,336 & 20,976 & 20,297 \\
\hline R-squared & 0.300 & 0.348 & 0.106 & 0.125 & 0.529 & 0.521 & 0.330 & 0.356 \\
\hline City FE & Yes & Yes & Yes & Yes & Yes & Yes & Yes & Yes \\
\hline
\end{tabular}

Notes: Standard errors are clustered at DHS survey cluster level

*** $\mathrm{p}<0.01, * * \mathrm{p}<0.05, * \mathrm{p}<0.1$ 


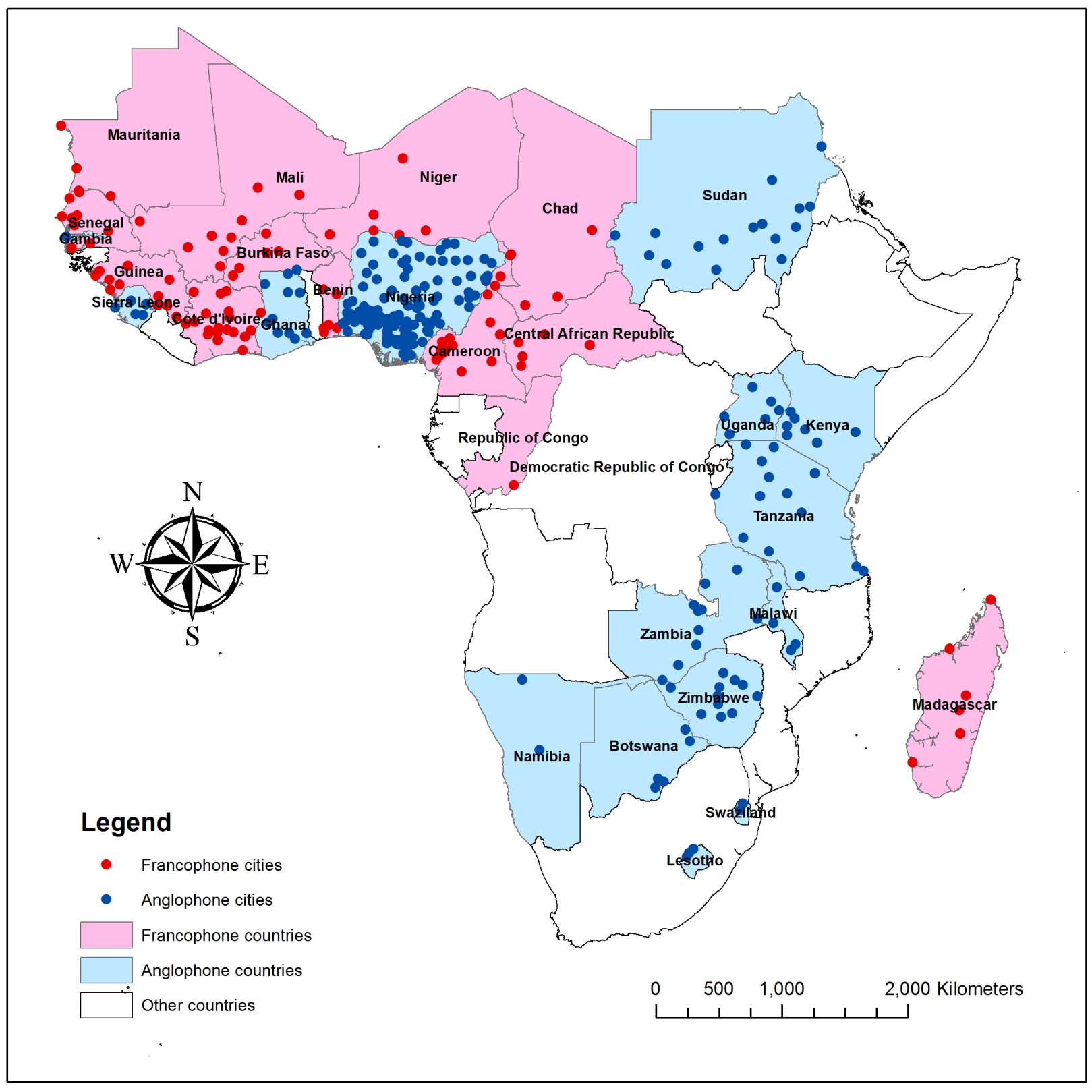

Figure 1a: Spatial distribution of full sample cities 


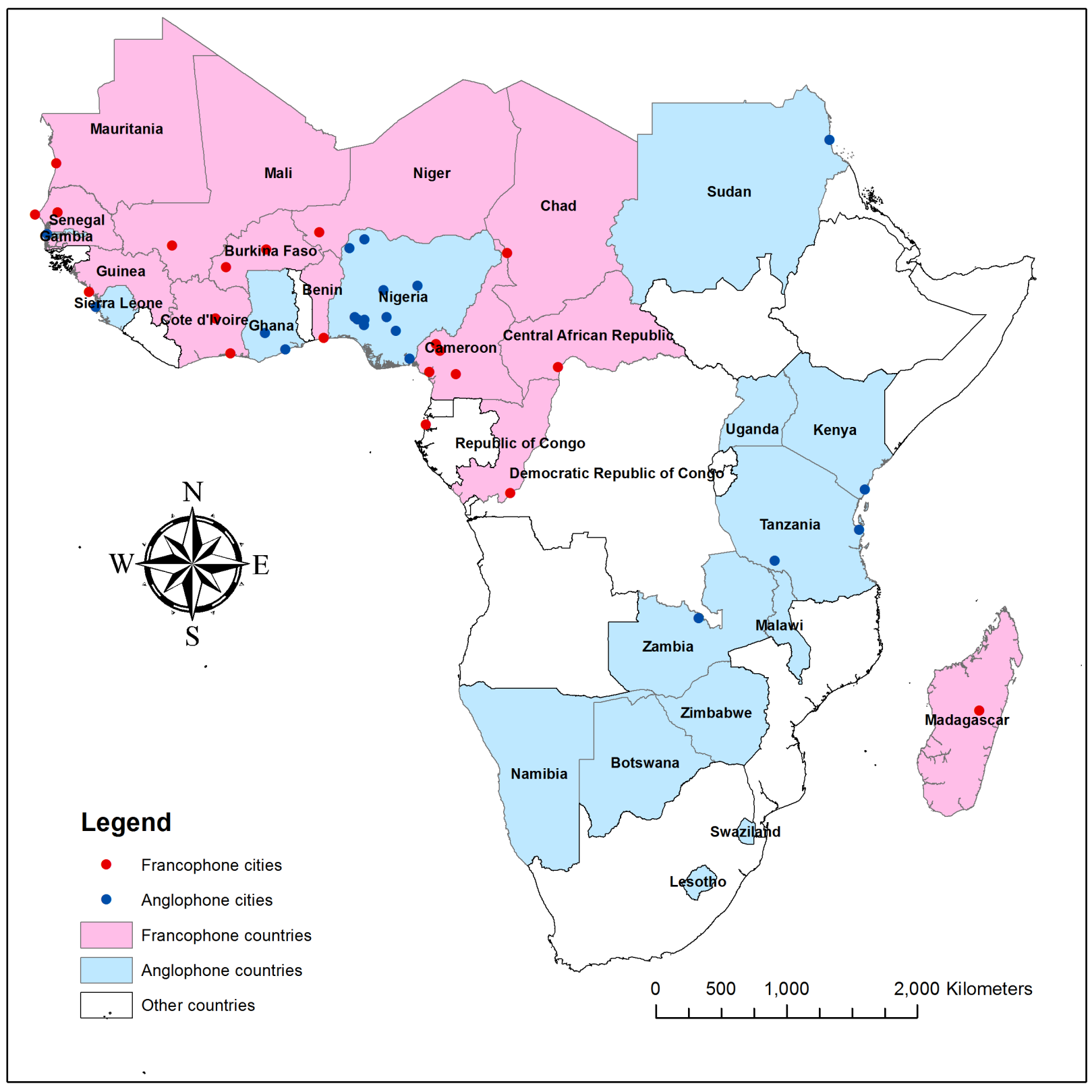

Figure 1b: Spatial distribution of 40 sample cities 
(a) 1990

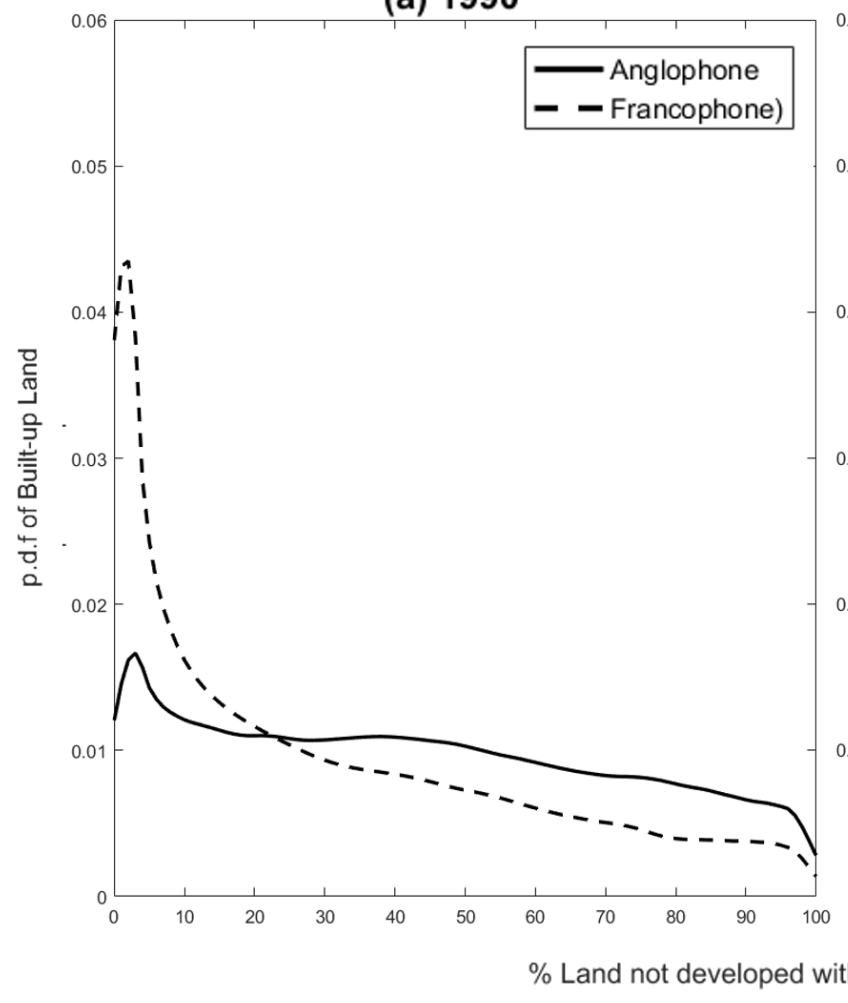

(b) 2014

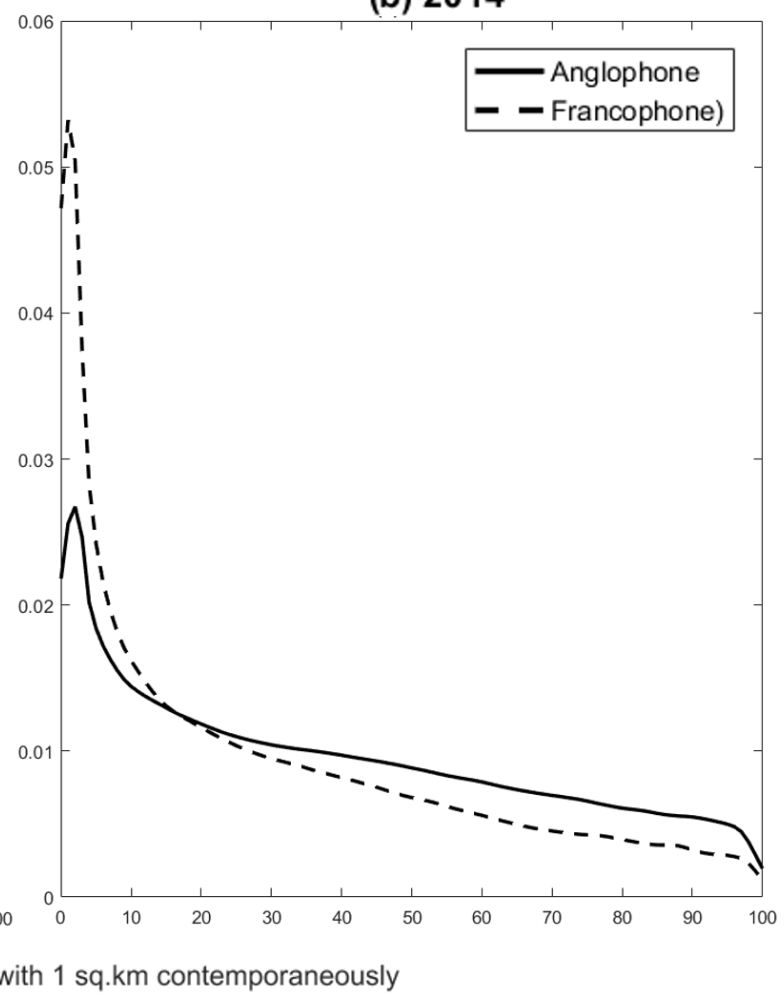

Figure 2: Probability function of Anglophone and Francophone built-up land across areas with different degrees of sprawl for (a) 1990 and (b) 2014 


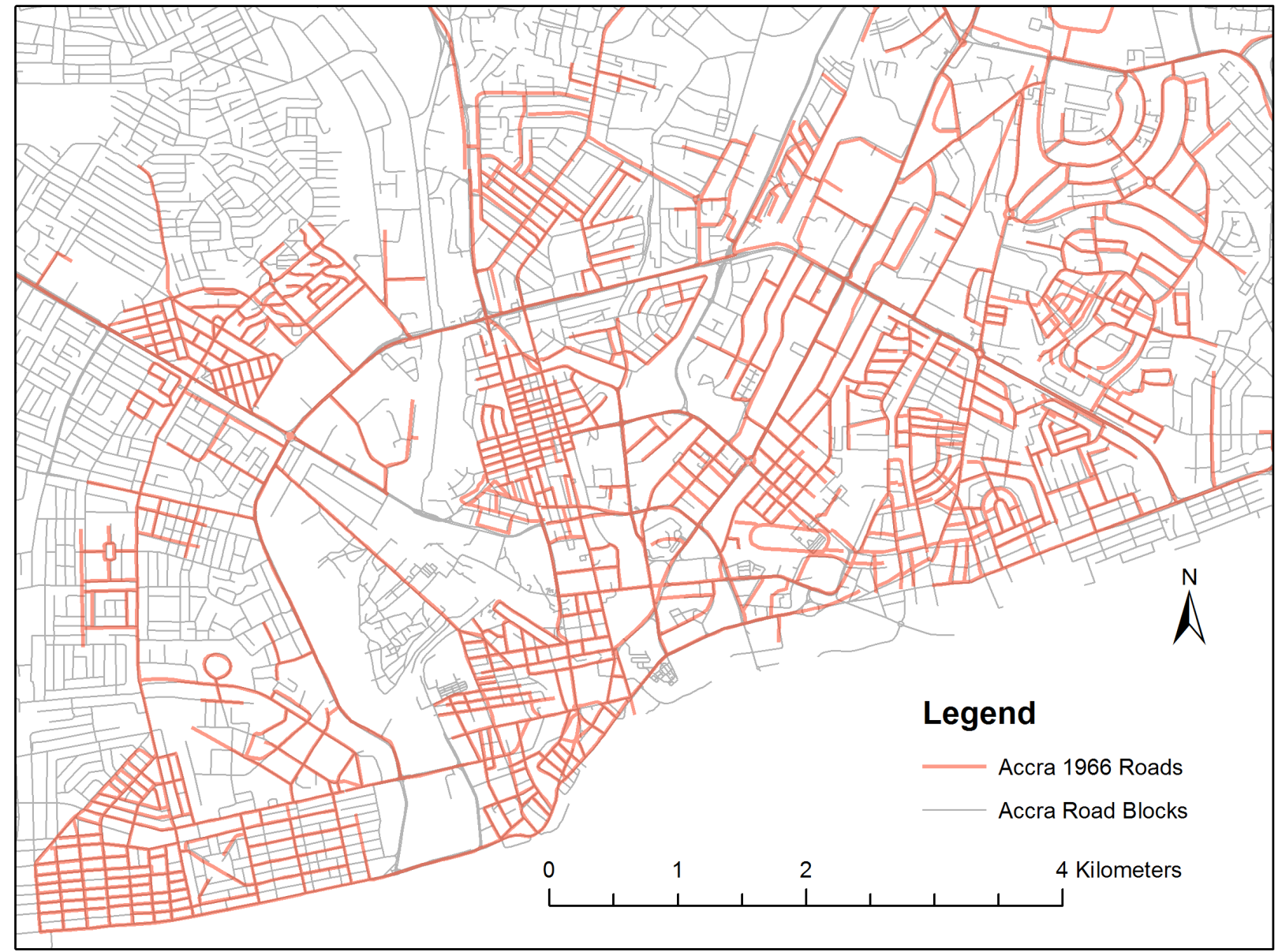

Figure 3a: Persistence of road blocks in Accra 


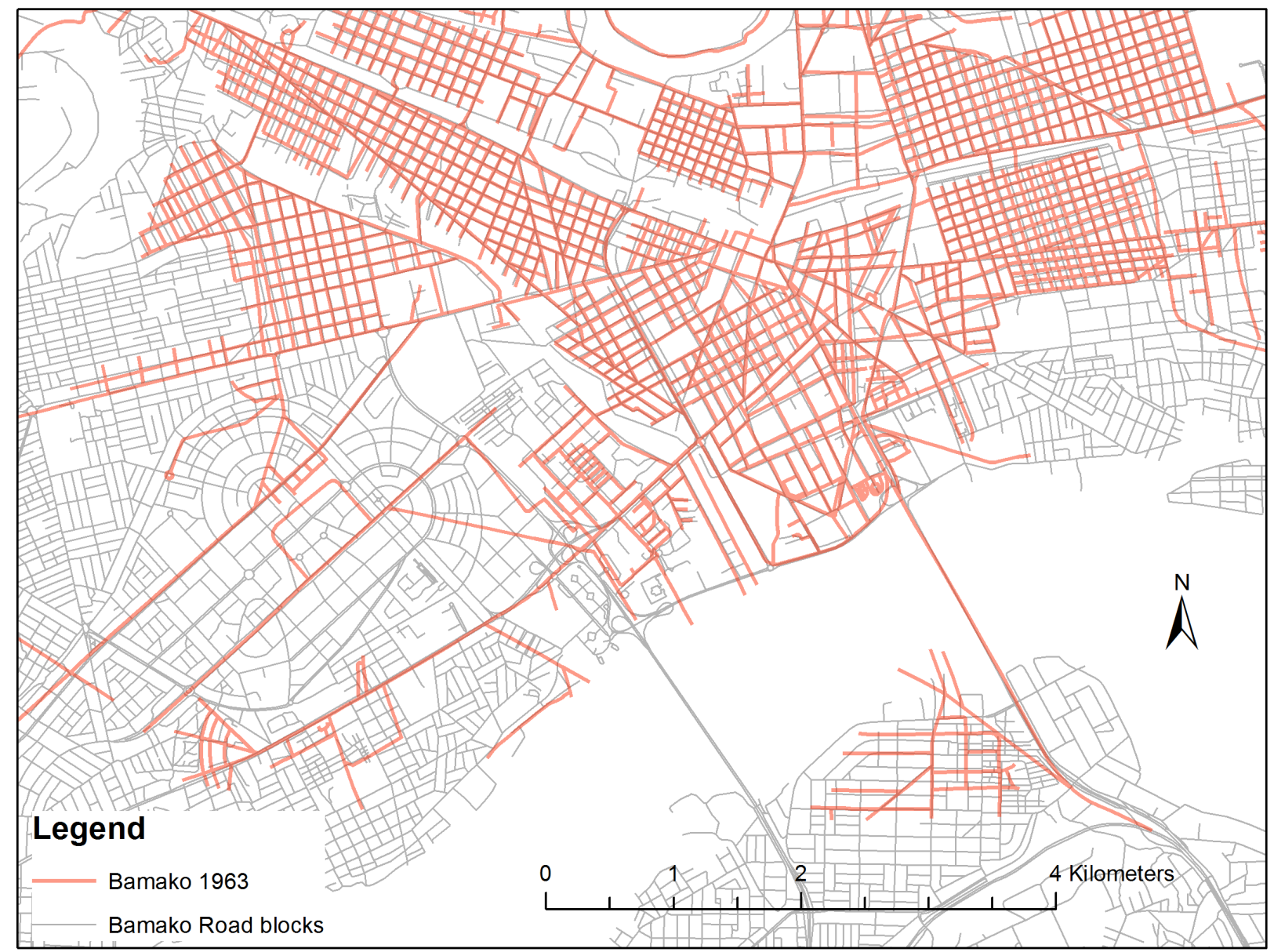

Figure 3b: Persistence of road blocks in Bamako 


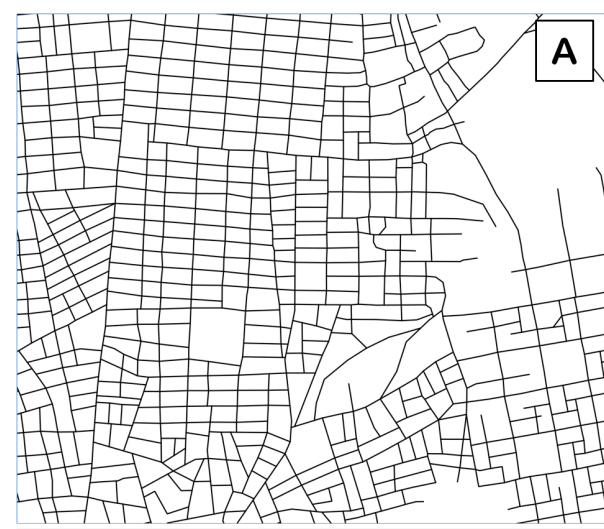

B
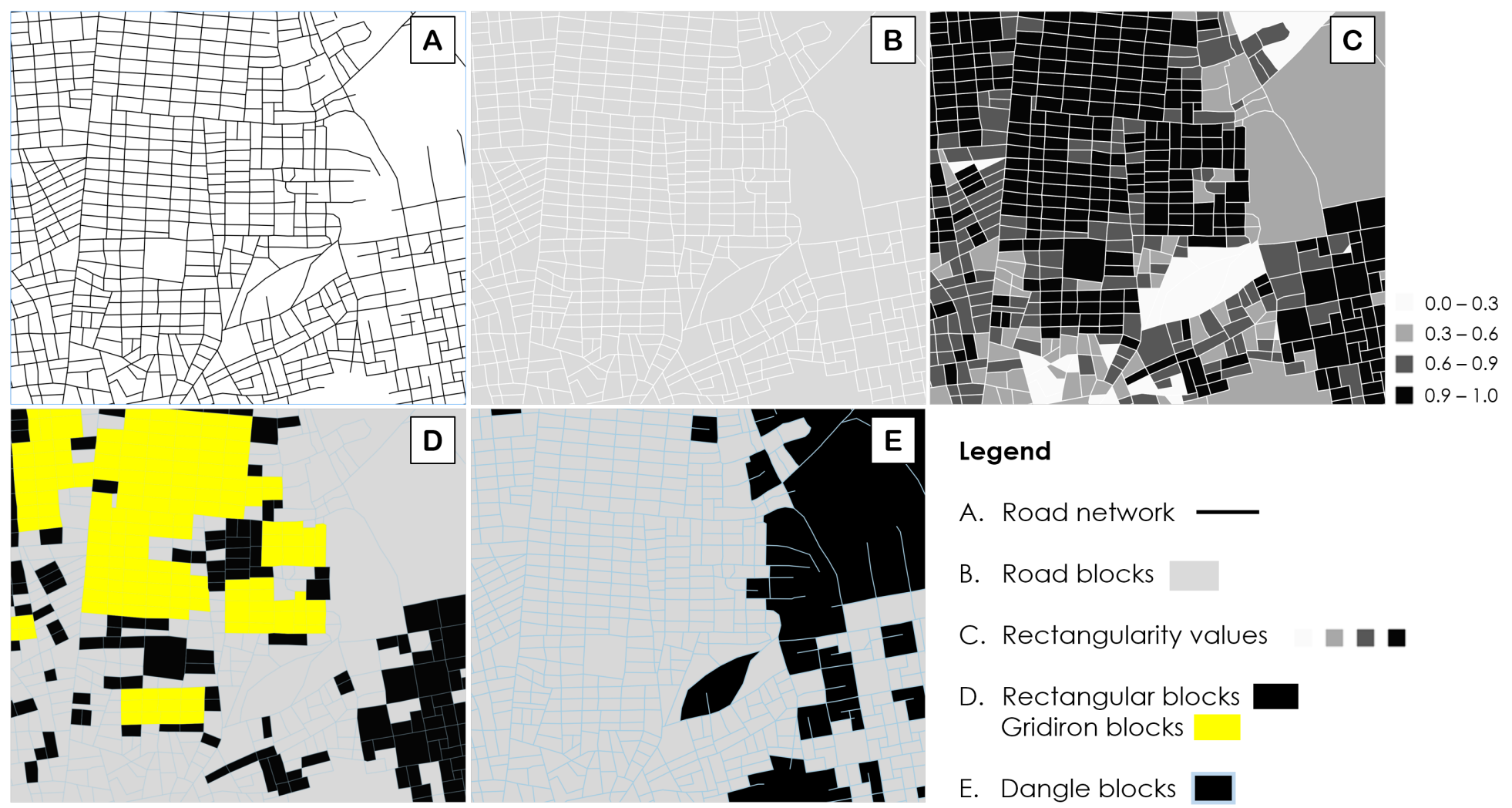

Legend

A. Road network

B. Road blocks

C. Rectangularity values

D. Rectangular blocks

Gridiron blocks

E. Dangle blocks

(Blue outline represents road network to illustrate the dangles)

Figure 4: Road blocks and rectangularity 


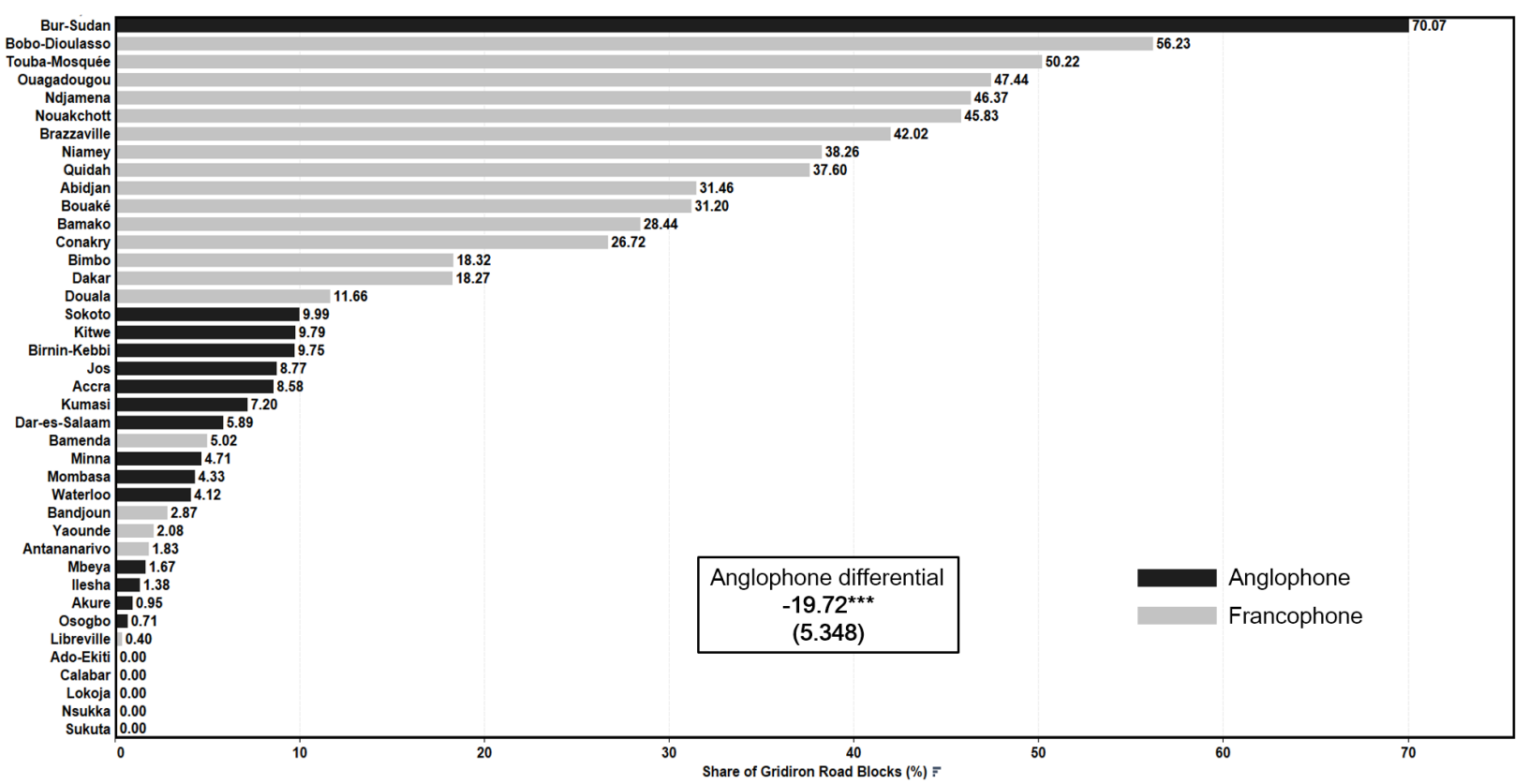

Figure 5: Share of gridiron road blocks within contemporary 5km

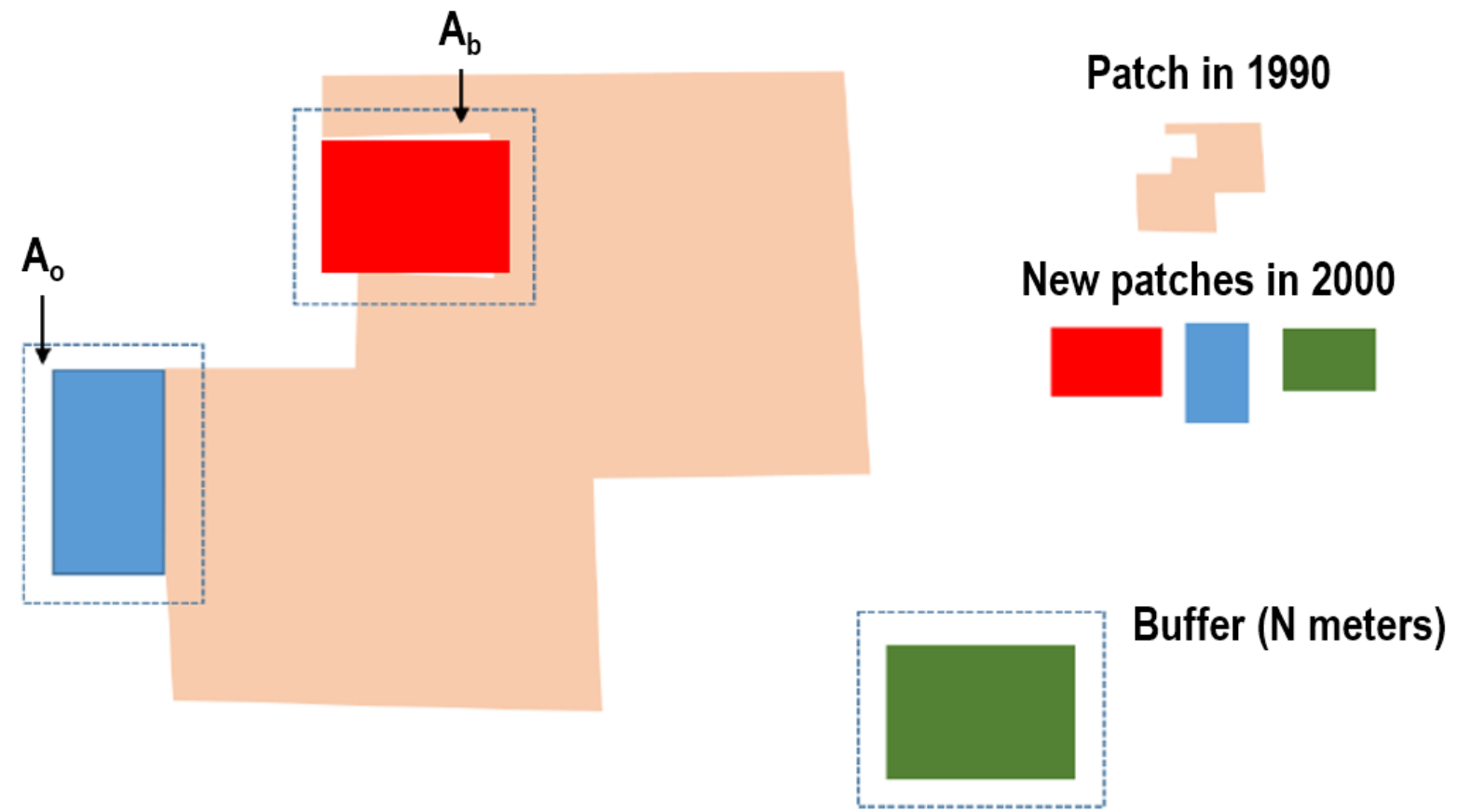

Figure 6: Illustration of using the landscape expansion index for defining leapfrog patches 


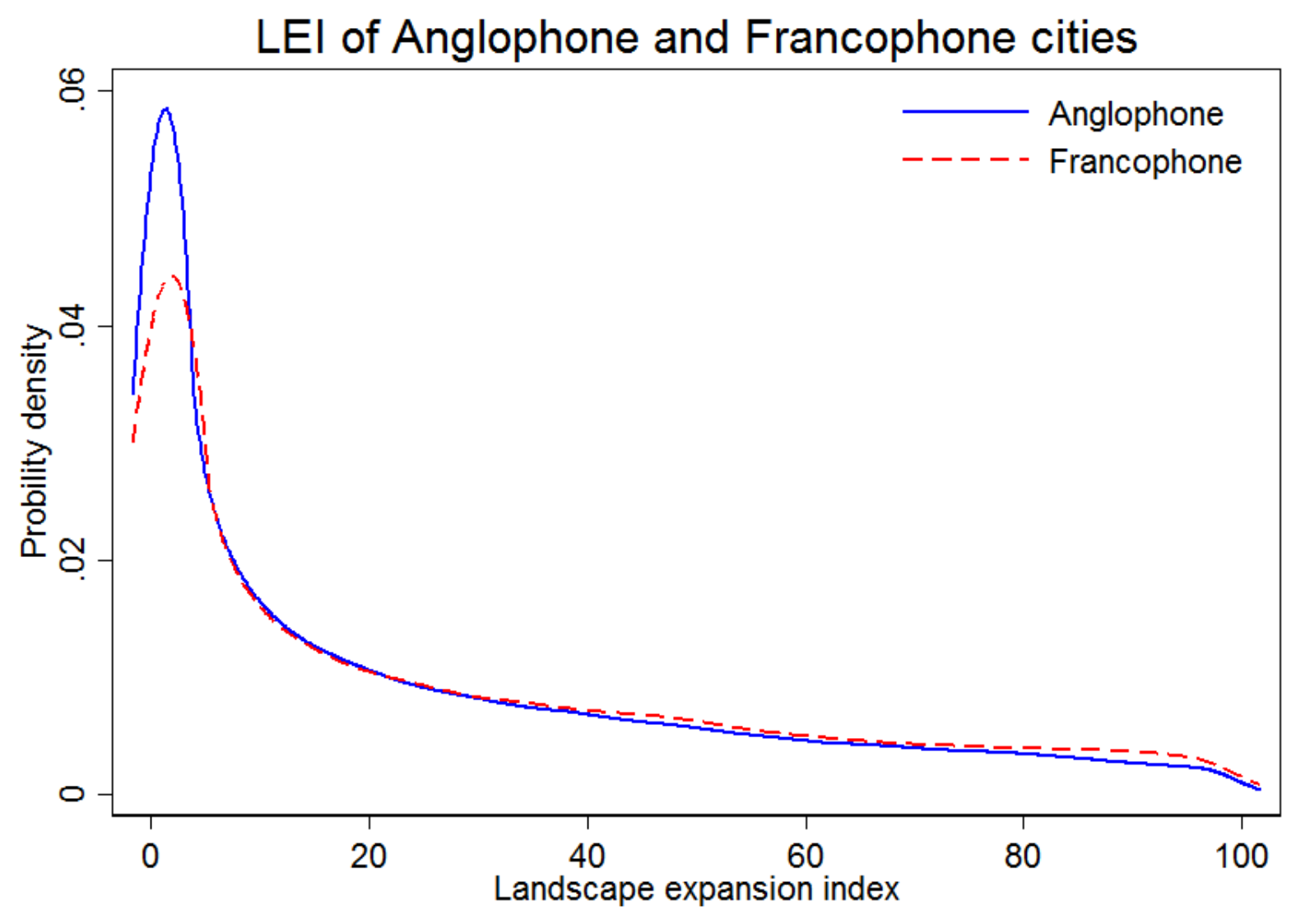

Figure 7: Probability function of LEI of patches by Anglophone and Francophone cities 


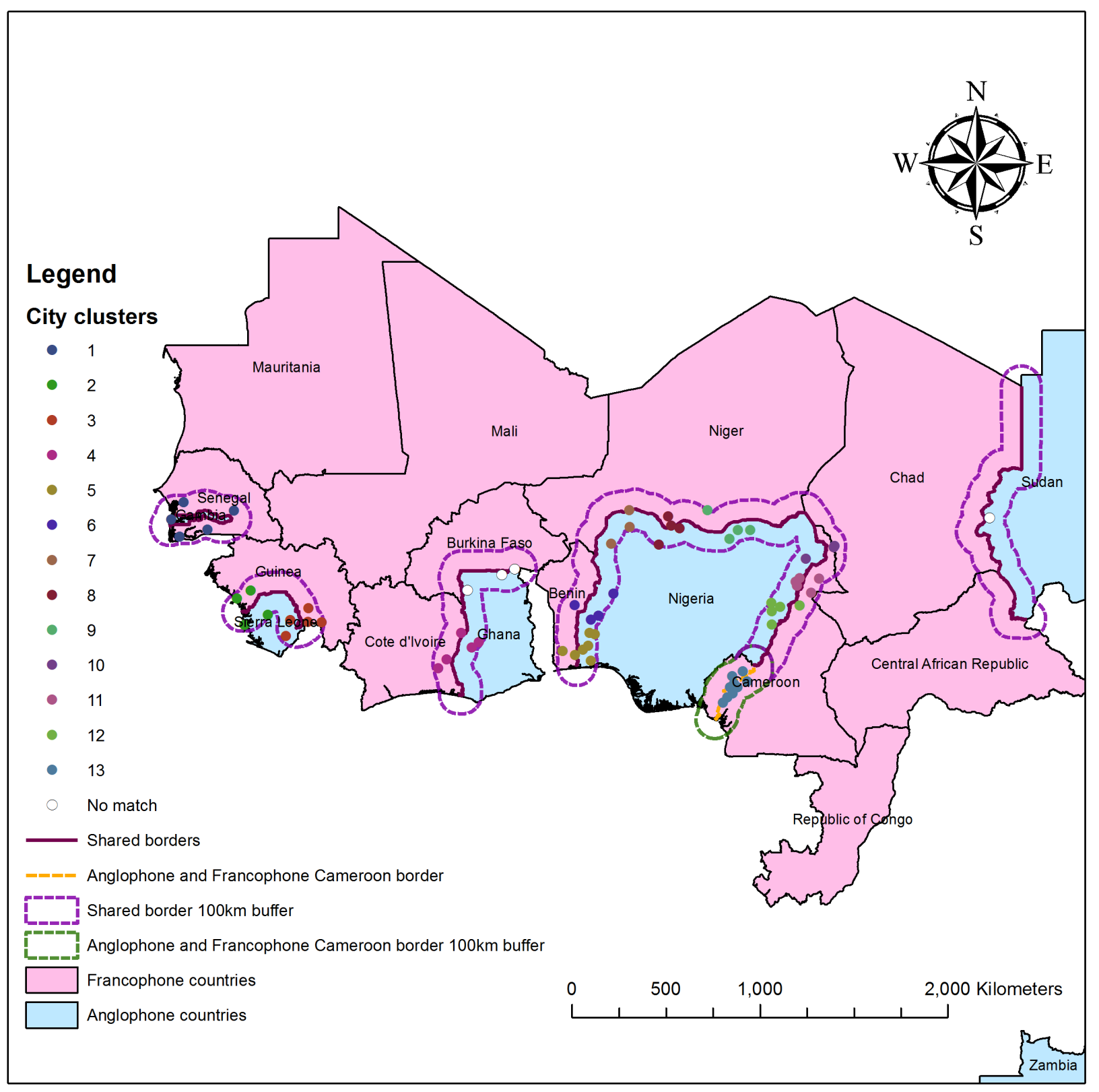

Figure 8: Shared borders 


\section{A On-line Appendix}

\section{A.1 City built cover boundary}

We adopted a smoothing algorithm to define the city built cover boundary. First, we measured the area of total built cover for each $500 \mathrm{~m} \times 500 \mathrm{~m}$ grid. Then the smoothing algorithm gives each grid the average built cover value of its neighbor grids and itself. The neighborhood is all queen and rook neighbors on the grid. Note if there is any grid in a neighborhood that has no built-up cover, the averaged built-up is set to be zero. This condition helps to eliminate scattered built-up and obtain continuous built cover area. Finally, we select the grids with neighbourhoods which average over $10 \%$ built cover, and use them to form the final built cover boundary of cities. 
Table A1: Sample cities and population

\begin{tabular}{|c|c|c|c|c|c|c|}
\hline City name & Country & $\begin{array}{l}\text { Anglphone } \\
\text { dummy }\end{array}$ & $\begin{array}{c}\text { Projected } \\
\text { population } \\
1990\end{array}$ & $\begin{array}{c}\text { Projected } \\
\text { population } \\
2012\end{array}$ & $\begin{array}{c}\text { Strict } \\
\text { colonial } \\
\text { origin } \\
\text { sample }\end{array}$ & $\begin{array}{c}40 \text { cities } \\
\text { sample }\end{array}$ \\
\hline Bohicon & Benin & 0 & 89,553 & 166,611 & & \\
\hline Djougou & Benin & 0 & 47,383 & 81,341 & & \\
\hline Lokossa & Benin & 0 & 30,328 & 70,048 & & \\
\hline Parakou & Benin & 0 & 96,206 & 216,706 & & \\
\hline Pobè & Benin & 0 & 35,163 & 67,425 & & \\
\hline Quidah & Benin & 0 & 921,859 & $1,922,874$ & & \\
\hline Toviklin & Benin & 0 & 35,688 & 66,505 & & \\
\hline Francistown & Botswana & 1 & 65,935 & 109,269 & Yes & \\
\hline Gaborone & Botswana & 1 & 215,068 & 487,079 & Yes & \\
\hline Kanye & Botswana & 1 & 30,552 & 47,698 & & \\
\hline Molepolole & Botswana & 1 & 35,517 & 67,791 & & \\
\hline Selebi-Phikwe & Botswana & 1 & 45,446 & 61,570 & & \\
\hline Banfora & Burkina Faso & 0 & 41,261 & 97,859 & & \\
\hline Bobo-Dioulasso & Burkina Faso & 0 & 262,478 & 645,198 & & \\
\hline Koudougou & Burkina Faso & 0 & 60,177 & 99,187 & & \\
\hline Ouagadougou & Burkina Faso & 0 & 578,653 & $2,213,074$ & & \\
\hline Ouahigouya & Burkina Faso & 0 & 44,462 & 89,579 & & \\
\hline Bafang & Cameroon & 0 & 37,503 & 33,806 & & \\
\hline Bamenda & Cameroon & 0 & 129,657 & 413,538 & & \\
\hline Bandjoun & Cameroon & 0 & 129,500 & 359,215 & & \\
\hline Bertoua & Cameroon & 0 & 48,871 & 116,686 & & \\
\hline Douala & Cameroon & 0 & 935,407 & $2,691,721$ & & \\
\hline Dschang & Cameroon & 0 & 39,347 & 80,013 & & \\
\hline Edéa & Cameroon & 0 & 52,976 & 74,076 & & \\
\hline
\end{tabular}


Continue: Table A1 sample cities and population

\begin{tabular}{|c|c|c|c|c|c|c|}
\hline City name & Country & $\begin{array}{l}\text { Anglphone } \\
\text { dummy }\end{array}$ & $\begin{array}{c}\text { Projected } \\
\text { population } \\
1990\end{array}$ & $\begin{array}{c}\text { Projected } \\
\text { population } \\
2012\end{array}$ & $\begin{array}{c}\text { Strict } \\
\text { colonial } \\
\text { origin } \\
\text { sample }\end{array}$ & $\begin{array}{l}40 \text { cities } \\
\text { sample }\end{array}$ \\
\hline Foumban & Cameroon & 0 & 60,988 & 96,722 & & \\
\hline Garoua & Cameroon & 0 & 154,400 & 287,668 & & \\
\hline Guider & Cameroon & 0 & 35,432 & 62,750 & & \\
\hline Kousséri & Cameroon & 0 & 58,443 & 108,520 & & \\
\hline Kumbo & Cameroon & 0 & 38,606 & 112,836 & & \\
\hline Loum & Cameroon & 0 & 40,726 & 60,213 & & \\
\hline Maroua & Cameroon & 0 & 133,940 & 243,578 & & \\
\hline Mbouda & Cameroon & 0 & 37,434 & 50,758 & & \\
\hline Meiganga & Cameroon & 0 & 32,793 & 40,857 & & \\
\hline Ngaoundéré & Cameroon & 0 & 87,298 & 198,223 & & \\
\hline Nkongsamba & Cameroon & 0 & 88,275 & 112,347 & & \\
\hline Yaounde & Cameroon & 0 & 771,858 & $2,744,391$ & & \\
\hline Bambari & $\begin{array}{c}\text { Central African } \\
\text { Republic }\end{array}$ & 0 & 38,985 & 43,081 & & \\
\hline Berbérati & $\begin{array}{c}\text { Central African } \\
\text { Republic }\end{array}$ & 0 & 45,426 & 110,757 & & \\
\hline Bimbo & $\begin{array}{c}\text { Central African } \\
\text { Republic }\end{array}$ & 0 & 492,970 & 995,932 & & \\
\hline Bossangoa & $\begin{array}{c}\text { Central African } \\
\text { Republic }\end{array}$ & 0 & 32,124 & 39,833 & & \\
\hline Bouar & $\begin{array}{c}\text { Central African } \\
\text { Republic }\end{array}$ & 0 & 39,766 & 40,765 & & \\
\hline Carnot & $\begin{array}{c}\text { Central African } \\
\text { Republic }\end{array}$ & 0 & 32,915 & 56,765 & & \\
\hline Abéché & Chad & 0 & 48,962 & 109,300 & & \\
\hline
\end{tabular}


Continue: Table A1 sample cities and population

\begin{tabular}{|c|c|c|c|c|c|c|}
\hline City name & Country & $\begin{array}{l}\text { Anglphone } \\
\text { dummy }\end{array}$ & $\begin{array}{c}\text { Projected } \\
\text { population } \\
1990\end{array}$ & $\begin{array}{c}\text { Projected } \\
\text { population } \\
2012\end{array}$ & $\begin{array}{c}\text { Strict } \\
\text { colonial } \\
\text { origin } \\
\text { sample }\end{array}$ & $\begin{array}{l}40 \text { cities } \\
\text { sample }\end{array}$ \\
\hline Moundou & Chad & 0 & 93,710 & 145,775 & & \\
\hline Ndjamena & Chad & 0 & 475,961 & $1,061,368$ & & \\
\hline Sarh & Chad & 0 & 71,999 & 101,946 & & \\
\hline Abengourou & Cote d'Ivoire & 0 & 61,400 & & & \\
\hline Abidjan & Cote d'Ivoire & 0 & $2,312,639$ & $4,395,000$ & & \\
\hline Akoupé & Cote d'Ivoire & 0 & 38,495 & & & \\
\hline Bondoukou & Cote d'Ivoire & 0 & 35,283 & & & \\
\hline Bouaflé & Cote d'Ivoire & 0 & 37,918 & & & \\
\hline Bouaké & Cote d'Ivoire & 0 & 352,785 & 536,719 & & \\
\hline Daloa & Cote d'Ivoire & 0 & 130,708 & & & \\
\hline Danané & Cote d'Ivoire & 0 & 34,582 & & & \\
\hline Dimbokro & Cote d'Ivoire & 0 & 39,581 & & & \\
\hline Ferkéssédougou & Cote d'Ivoire & 0 & 40,675 & & & \\
\hline Gagnoa & Cote d'Ivoire & 0 & 112,890 & & & \\
\hline Issia & Cote d'Ivoire & 0 & 30,922 & & & \\
\hline Katiola & Cote d'Ivoire & 0 & 34,581 & & & \\
\hline Korhogo & Cote d'Ivoire & 0 & 115,302 & & & \\
\hline Man & Cote d'Ivoire & 0 & 94,435 & & & \\
\hline Odienné & Cote d'Ivoire & 0 & 31,202 & & & \\
\hline Sinfra & Cote d'Ivoire & 0 & 37,773 & & & \\
\hline Séguéla & Cote d'Ivoire & 0 & 31,517 & & & \\
\hline Yamoussoukro & Cote d'Ivoire & 0 & 139,062 & & & \\
\hline Libreville & Gabon & 0 & 394,152 & 694,622 & & \\
\hline Sukuta & Gambia & 1 & 357,893 & 460,450 & Yes & Yes \\
\hline Accra & Ghana & 1 & $2,004,164$ & $3,689,581$ & Yes & Yes \\
\hline
\end{tabular}


Continue: Table A1 sample cities and population

\begin{tabular}{|c|c|c|c|c|c|c|}
\hline City name & Country & $\begin{array}{l}\text { Anglphone } \\
\text { dummy }\end{array}$ & $\begin{array}{c}\text { Projected } \\
\text { population } \\
1990\end{array}$ & $\begin{array}{c}\text { Projected } \\
\text { population } \\
2012\end{array}$ & $\begin{array}{c}\text { Strict } \\
\text { colonial } \\
\text { origin } \\
\text { sample }\end{array}$ & $\begin{array}{l}40 \text { cities } \\
\text { sample }\end{array}$ \\
\hline Bawku & Ghana & 1 & 39,747 & 63,318 & & \\
\hline Bolgatanga & Ghana & 1 & 37,953 & 69,431 & & \\
\hline Dzodze & Ghana & 1 & 52,458 & & & \\
\hline Но & Ghana & 1 & 45,396 & 116,172 & & \\
\hline Koforidua & Ghana & 1 & 68,148 & 129,122 & Yes & \\
\hline Kumasi & Ghana & 1 & 836,568 & $2,382,131$ & & Yes \\
\hline Nkawkaw & Ghana & 1 & 35,816 & 48,870 & & \\
\hline Sunyani & Ghana & 1 & 46,279 & 76,966 & & \\
\hline Tamale & Ghana & 1 & 177,409 & 409,675 & & \\
\hline Techiman & Ghana & 1 & 34,094 & 69,700 & & \\
\hline Wa & Ghana & 1 & 45,405 & 71,967 & & \\
\hline Yendi & Ghana & 1 & 34,652 & 54,365 & & \\
\hline Boké & Guinea & 0 & 35,332 & 58,679 & & \\
\hline Conakry & Guinea & 0 & 942,708 & $1,824,765$ & & \\
\hline Fria & Guinea & 0 & 41,303 & 53,703 & & \\
\hline Guéckédou & Guinea & 0 & 85,391 & 64,617 & & \\
\hline Kamsar & Guinea & 0 & 55,242 & 82,002 & & \\
\hline Kankan & Guinea & 0 & 80,409 & 180,127 & & \\
\hline Kindia & Guinea & 0 & 85,776 & 129,993 & & \\
\hline Kissidougou & Guinea & 0 & 59,539 & 86,954 & & \\
\hline Labé & Guinea & 0 & 40,570 & 84,218 & & \\
\hline Macenta & Guinea & 0 & 44,266 & 56,709 & & \\
\hline Mamou & Guinea & 0 & 45,178 & 63,059 & & \\
\hline Nzérékoré & Guinea & 0 & 88,082 & 181,799 & & \\
\hline Eldoret & Kenya & 1 & 116,456 & 285,187 & & \\
\hline
\end{tabular}


Continue: Table A1 sample cities and population

\begin{tabular}{|c|c|c|c|c|c|c|}
\hline City name & Country & $\begin{array}{l}\text { Anglphone } \\
\text { dummy }\end{array}$ & $\begin{array}{c}\text { Projected } \\
\text { population } \\
1990\end{array}$ & $\begin{array}{c}\text { Projected } \\
\text { population } \\
2012\end{array}$ & $\begin{array}{c}\text { Strict } \\
\text { colonial } \\
\text { origin } \\
\text { sample }\end{array}$ & $\begin{array}{l}40 \text { cities } \\
\text { sample }\end{array}$ \\
\hline Garissa & Kenya & 1 & 32,881 & 161,277 & & \\
\hline Kisii & Kenya & 1 & 47,004 & 74,984 & & \\
\hline Kisumu & Kenya & 1 & 194,711 & 326,009 & & \\
\hline Kitale & Kenya & 1 & 56,884 & 80,007 & & \\
\hline Mombasa & Kenya & 1 & 491,834 & $1,167,440$ & Yes & Yes \\
\hline Nairobi & Kenya & 1 & $1,516,055$ & $5,044,352$ & Yes & \\
\hline Nakuru & Kenya & 1 & 170,002 & 336,431 & Yes & \\
\hline Maputsoe & Lesotho & 1 & 59,779 & 103,567 & & \\
\hline Maseru & Lesotho & 1 & 117,442 & 178,016 & Yes & \\
\hline Teyateyaneng & Lesotho & 1 & 42,583 & 61,599 & & \\
\hline Antananarivo & Madagascar & 0 & 675,058 & $1,300,000$ & & \\
\hline Antsirabe & Madagascar & 0 & 117,026 & & & \\
\hline Antsiranana & Madagascar & 0 & 54,808 & & & \\
\hline Fianarantsoa & Madagascar & 0 & 101,428 & & & \\
\hline Mahajanga & Madagascar & 0 & 99,126 & & & \\
\hline Toliara & Madagascar & 0 & 75,032 & & & \\
\hline Blantyre & Malawi & 1 & 372,552 & 738,274 & Yes & \\
\hline Lilongwe & Malawi & 1 & 268,767 & 799,762 & & \\
\hline Mzuzu & Malawi & 1 & 59,752 & 159,233 & & \\
\hline Zomba & Malawi & 1 & 48,517 & 99,277 & & \\
\hline Bamako & Mali & 0 & 758,125 & $2,452,195$ & & \\
\hline Gao & Mali & 0 & 54,413 & 99,059 & & \\
\hline Kayes & Mali & 0 & 55,029 & 149,909 & & \\
\hline Koutiala & Mali & 0 & 55,163 & 167,010 & & \\
\hline Mopti & Mali & 0 & 76,285 & 134,933 & & \\
\hline
\end{tabular}


Continue: Table A1 sample cities and population

\begin{tabular}{|c|c|c|c|c|c|c|}
\hline City name & Country & $\begin{array}{l}\text { Anglphone } \\
\text { dummy }\end{array}$ & $\begin{array}{c}\text { Projected } \\
\text { population } \\
1990\end{array}$ & $\begin{array}{c}\text { Projected } \\
\text { population } \\
2012\end{array}$ & $\begin{array}{c}\text { Strict } \\
\text { colonial } \\
\text { origin } \\
\text { sample }\end{array}$ & $\begin{array}{l}40 \text { cities } \\
\text { sample }\end{array}$ \\
\hline San & Mali & 0 & 34,466 & 73,915 & & \\
\hline Sikasso & Mali & 0 & 87,024 & 261,123 & & \\
\hline Ségou & Mali & 0 & 92,519 & 188,365 & & \\
\hline Tombouctou & Mali & 0 & 31,338 & 64,488 & & \\
\hline Kaédi & Mauritania & 0 & 31,104 & 47,803 & & \\
\hline Nouadhibou & Mauritania & 0 & 61,209 & 113,789 & & \\
\hline Nouakchott & Mauritania & 0 & 418,294 & 938,154 & & \\
\hline Rosso & Mauritania & 0 & 30,530 & 50,861 & & \\
\hline Oshakati & Namibia & 1 & 34,552 & 83,432 & & \\
\hline Windhoek & Namibia & 1 & 140,410 & 358,996 & Yes & \\
\hline Arlit & Niger & 0 & 36,261 & 78,651 & & \\
\hline Birni-N'Konni & Niger & 0 & 31,023 & 63,169 & & \\
\hline Maradi & Niger & 0 & 115,144 & 292,762 & & \\
\hline Niamey & Niger & 0 & 427,540 & 978,029 & & \\
\hline Tahoua & Niger & 0 & 52,951 & 117,826 & & \\
\hline Zinder & Niger & 0 & 126,517 & 235,605 & & \\
\hline Aba & Nigeria & 1 & 444,346 & $1,091,560$ & Yes & \\
\hline Abakaliki & Nigeria & 1 & 158,289 & 439,893 & & \\
\hline Abraka & Nigeria & 1 & 119,940 & 259,762 & & \\
\hline Abuja & Nigeria & 1 & 384,364 & $3,028,557$ & Yes & \\
\hline Ado-Ekiti & Nigeria & 1 & 291,866 & 647,182 & & Yes \\
\hline Afikpo & Nigeria & 1 & 74,524 & 141,516 & & \\
\hline Agbor & Nigeria & 1 & 67,857 & 129,551 & & \\
\hline Aiyetoro & Nigeria & 1 & 43,862 & 49,195 & & \\
\hline Ajaokuta & Nigeria & 1 & 57,702 & 82,522 & & \\
\hline
\end{tabular}


Continue: Table A1 sample cities and population

\begin{tabular}{|c|c|c|c|c|c|c|}
\hline City name & Country & $\begin{array}{l}\text { Anglphone } \\
\text { dummy }\end{array}$ & $\begin{array}{c}\text { Projected } \\
\text { population } \\
1990\end{array}$ & $\begin{array}{c}\text { Projected } \\
\text { population } \\
2012\end{array}$ & $\begin{array}{c}\text { Strict } \\
\text { colonial } \\
\text { origin } \\
\text { sample }\end{array}$ & $\begin{array}{l}40 \text { cities } \\
\text { sample }\end{array}$ \\
\hline Akure & Nigeria & 1 & 356,210 & 675,366 & Yes & Yes \\
\hline Akwanga & Nigeria & 1 & 41,705 & 91,050 & & \\
\hline Ankpa & Nigeria & 1 & 39,291 & 70,006 & & \\
\hline Argungu & Nigeria & 1 & 40,367 & 87,700 & & \\
\hline Auchi & Nigeria & 1 & 72,986 & 147,505 & & \\
\hline Azare & Nigeria & 1 & 65,234 & 124,820 & & \\
\hline Bama & Nigeria & 1 & 64,076 & 107,727 & & \\
\hline Bauchi & Nigeria & 1 & 232,939 & 435,001 & & \\
\hline Bida & Nigeria & 1 & 85,084 & 233,626 & & \\
\hline Birnin-Kebbi & Nigeria & 1 & 142,795 & 347,188 & & Yes \\
\hline Biu & Nigeria & 1 & 49,067 & 105,096 & & \\
\hline Calabar & Nigeria & 1 & 159,490 & 436,394 & Yes & Yes \\
\hline Damaturu & Nigeria & 1 & 36,386 & 85,027 & & \\
\hline Doma & Nigeria & 1 & 42,091 & 83,383 & & \\
\hline Dutse & Nigeria & 1 & 152,198 & 193,025 & & \\
\hline Egbe & Nigeria & 1 & 34,188 & 89,210 & & \\
\hline Egume & Nigeria & 1 & 71,733 & 133,130 & & \\
\hline Ejigbo & Nigeria & 1 & 31,525 & 92,402 & & \\
\hline Ekehen & Nigeria & 1 & 30,566 & 57,101 & & \\
\hline Emure-Ekiti & Nigeria & 1 & 67,364 & 78,826 & & \\
\hline Enugu & Nigeria & 1 & 503,384 & 912,182 & Yes & \\
\hline Funtua & Nigeria & 1 & 89,954 & 183,064 & Yes & \\
\hline Ganye & Nigeria & 1 & 58,710 & 102,167 & & \\
\hline Gashua & Nigeria & 1 & 52,963 & 82,391 & & \\
\hline Gboko & Nigeria & 1 & 184,658 & 362,100 & & \\
\hline
\end{tabular}


Continue: Table A1 sample cities and population

\begin{tabular}{|c|c|c|c|c|c|c|}
\hline City name & Country & $\begin{array}{l}\text { Anglphone } \\
\text { dummy }\end{array}$ & $\begin{array}{c}\text { Projected } \\
\text { population } \\
1990\end{array}$ & $\begin{array}{c}\text { Projected } \\
\text { population } \\
2012\end{array}$ & $\begin{array}{c}\text { Strict } \\
\text { colonial } \\
\text { origin } \\
\text { sample }\end{array}$ & $\begin{array}{l}40 \text { cities } \\
\text { sample }\end{array}$ \\
\hline Gombe & Nigeria & 1 & 191,795 & 372,804 & & \\
\hline Gusau & Nigeria & 1 & 135,788 & 242,556 & Yes & \\
\hline Hadejia & Nigeria & 1 & 45,276 & 94,181 & & \\
\hline Ibadan & Nigeria & 1 & $1,711,452$ & $2,911,228$ & Yes & \\
\hline Idah & Nigeria & 1 & 82,520 & 161,370 & & \\
\hline Idanre & Nigeria & 1 & 49,885 & 97,053 & & \\
\hline Ife & Nigeria & 1 & 263,879 & 491,656 & & \\
\hline Igbo-Ora & Nigeria & 1 & 31,519 & 76,914 & & \\
\hline Igboho & Nigeria & 1 & 31,854 & 62,311 & & \\
\hline Ihiala & Nigeria & 1 & 96,474 & & Yes & \\
\hline Ikare & Nigeria & 1 & 147,132 & 364,228 & Yes & \\
\hline Ikirun & Nigeria & 1 & 215,476 & 427,992 & Yes & \\
\hline Ikole & Nigeria & 1 & 56,932 & 100,183 & & \\
\hline Ikom & Nigeria & 1 & 40,718 & 52,109 & & \\
\hline Ikot-Ekpene & Nigeria & 1 & 146,477 & & & \\
\hline Ikot-Etim & Nigeria & 1 & 87,282 & 165,044 & & \\
\hline Ila & Nigeria & 1 & 43,213 & 59,975 & & \\
\hline Ilesha & Nigeria & 1 & 139,202 & 332,008 & Yes & Yes \\
\hline Ilorin & Nigeria & 1 & 538,446 & 833,589 & Yes & \\
\hline Ilutitun & Nigeria & 1 & 45,214 & 70,917 & & \\
\hline Iseyin & Nigeria & 1 & 47,732 & 174,531 & Yes & \\
\hline Iwo & Nigeria & 1 & 88,314 & 240,838 & Yes & \\
\hline Jalingo & Nigeria & 1 & 83,219 & 176,451 & & \\
\hline Jega & Nigeria & 1 & 32,799 & 69,227 & & \\
\hline Jibia & Nigeria & 1 & 35,397 & 56,556 & & \\
\hline
\end{tabular}


Continue: Table A1 sample cities and population

\begin{tabular}{|c|c|c|c|c|c|c|}
\hline City name & Country & $\begin{array}{l}\text { Anglphone } \\
\text { dummy }\end{array}$ & $\begin{array}{c}\text { Projected } \\
\text { population } \\
1990\end{array}$ & $\begin{array}{c}\text { Projected } \\
\text { population } \\
2012\end{array}$ & $\begin{array}{c}\text { Strict } \\
\text { colonial } \\
\text { origin } \\
\text { sample }\end{array}$ & $\begin{array}{l}40 \text { cities } \\
\text { sample }\end{array}$ \\
\hline Jimeta & Nigeria & 1 & 238,746 & 567,818 & & \\
\hline Jos & Nigeria & 1 & 487,013 & 789,950 & & Yes \\
\hline Kaduna & Nigeria & 1 & 849,035 & $1,139,643$ & Yes & \\
\hline Kafanchan & Nigeria & 1 & 41,236 & 132,111 & & \\
\hline Kano & Nigeria & 1 & $1,385,370$ & $3,734,597$ & & \\
\hline Katsina & Nigeria & 1 & 189,505 & 425,669 & Yes & \\
\hline Katsina-Ala & Nigeria & 1 & 43,751 & 74,895 & & \\
\hline Kontagora & Nigeria & 1 & 60,584 & 108,312 & & \\
\hline Lafia & Nigeria & 1 & 152,660 & 312,263 & & \\
\hline Lagos & Nigeria & 1 & $6,327,849$ & $14,564,075$ & Yes & \\
\hline Langtang & Nigeria & 1 & 65,532 & 121,295 & & \\
\hline Lokoja & Nigeria & 1 & 63,547 & 375,656 & & Yes \\
\hline Maiduguri & Nigeria & 1 & 490,729 & 694,554 & Yes & \\
\hline Makurdi & Nigeria & 1 & 179,494 & 301,249 & & \\
\hline Malumfashi & Nigeria & 1 & 46,775 & 58,968 & Yes & \\
\hline Maya-Belwa & Nigeria & 1 & 30,627 & 42,151 & & \\
\hline Michika & Nigeria & 1 & 48,163 & 74,898 & & \\
\hline Minna & Nigeria & 1 & 98,628 & 459,441 & & Yes \\
\hline Mubi & Nigeria & 1 & 80,666 & 127,945 & & \\
\hline Nasarawa & Nigeria & 1 & 30,873 & 57,046 & & \\
\hline New-Bussa & Nigeria & 1 & 40,675 & 83,317 & Yes & \\
\hline Nguru & Nigeria & 1 & 44,872 & 103,062 & Yes & \\
\hline Nkume & Nigeria & 1 & 129,318 & & & \\
\hline Nsukka & Nigeria & 1 & 638,402 & $1,918,146$ & & Yes \\
\hline Numan & Nigeria & 1 & 72,049 & 77,368 & & \\
\hline
\end{tabular}


Continue: Table A1 sample cities and population

\begin{tabular}{|c|c|c|c|c|c|c|}
\hline City name & Country & $\begin{array}{l}\text { Anglphone } \\
\text { dummy }\end{array}$ & $\begin{array}{c}\text { Projected } \\
\text { population } \\
1990\end{array}$ & $\begin{array}{c}\text { Projected } \\
\text { population } \\
2012\end{array}$ & $\begin{array}{c}\text { Strict } \\
\text { colonial } \\
\text { origin } \\
\text { sample }\end{array}$ & $\begin{array}{l}40 \text { cities } \\
\text { sample }\end{array}$ \\
\hline Obudu & Nigeria & 1 & 59,422 & 167,241 & & \\
\hline Ogbomosho & Nigeria & 1 & 134,065 & 383,364 & & \\
\hline Oguma & Nigeria & 1 & 35,039 & 72,981 & & \\
\hline Ogwashi-Uku & Nigeria & 1 & 42,955 & 67,482 & & \\
\hline Okeho & Nigeria & 1 & 41,304 & 105,183 & & \\
\hline Okenne & Nigeria & 1 & 85,307 & 376,128 & & \\
\hline Okigwi & Nigeria & 1 & 33,699 & 83,387 & & \\
\hline Okitipupa & Nigeria & 1 & 68,819 & 113,745 & & \\
\hline Okpakeke & Nigeria & 1 & 31,662 & 58,191 & & \\
\hline Okpo & Nigeria & 1 & 30,700 & 59,740 & & \\
\hline Omu-Aran & Nigeria & 1 & 47,679 & 81,069 & & \\
\hline Omuo-Ekiti & Nigeria & 1 & 31,118 & 99,172 & & \\
\hline Ondo & Nigeria & 1 & 228,481 & 426,176 & Yes & \\
\hline Onitsha & Nigeria & 1 & 956,207 & $8,290,101$ & Yes & \\
\hline Ore & Nigeria & 1 & 45,689 & 102,651 & & \\
\hline Oro-Esie-Iludin & Nigeria & 1 & 46,096 & 75,454 & & \\
\hline Osogbo & Nigeria & 1 & 497,049 & 774,670 & Yes & Yes \\
\hline Otun-Ekiti & Nigeria & 1 & 33,762 & 41,416 & & \\
\hline Oturkpo & Nigeria & 1 & 79,827 & 147,733 & & \\
\hline Owo & Nigeria & 1 & 103,021 & 186,305 & Yes & \\
\hline Oye-Ekiti & Nigeria & 1 & 60,751 & 80,981 & & \\
\hline Oyo & Nigeria & 1 & 188,026 & 363,371 & & \\
\hline Potiskum & Nigeria & 1 & 46,192 & 241,243 & & \\
\hline Saki & Nigeria & 1 & 74,705 & 253,572 & & \\
\hline Shendam & Nigeria & 1 & 34,042 & 42,405 & & \\
\hline
\end{tabular}


Continue: Table A1 sample cities and population

\begin{tabular}{|c|c|c|c|c|c|c|}
\hline City name & Country & $\begin{array}{l}\text { Anglphone } \\
\text { dummy }\end{array}$ & $\begin{array}{c}\text { Projected } \\
\text { population } \\
1990\end{array}$ & $\begin{array}{c}\text { Projected } \\
\text { population } \\
2012\end{array}$ & $\begin{array}{l}\text { Strict } \\
\text { colonial } \\
\text { origin } \\
\text { sample }\end{array}$ & $\begin{array}{l}40 \text { cities } \\
\text { sample }\end{array}$ \\
\hline Sokoto & Nigeria & 1 & 310,603 & 606,753 & Yes & Yes \\
\hline Takum & Nigeria & 1 & 31,065 & 53,909 & & \\
\hline Uba & Nigeria & 1 & 55,350 & 70,447 & & \\
\hline Ugep & Nigeria & 1 & 34,279 & 149,847 & & \\
\hline Umuahia & Nigeria & 1 & 116,721 & & & \\
\hline Uromi & Nigeria & 1 & 182,758 & 365,049 & & \\
\hline Uyo & Nigeria & 1 & 197,529 & $2,513,616$ & & \\
\hline Vande-Ikya & Nigeria & 1 & 35,671 & 64,535 & & \\
\hline Wukari & Nigeria & 1 & 43,003 & 83,693 & & \\
\hline Yelwa & Nigeria & 1 & 35,055 & 72,400 & & \\
\hline Zaki-Biam & Nigeria & 1 & 54,169 & 83,361 & & \\
\hline Zaria & Nigeria & 1 & 375,845 & 747,127 & & \\
\hline Zuru & Nigeria & 1 & 49,083 & 110,647 & & \\
\hline Brazzaville & Republic of Congo & 0 & 731,625 & $1,652,847$ & & \\
\hline Dakar & Senegal & 0 & $1,975,856$ & $3,435,250$ & & \\
\hline Diourbel & Senegal & 0 & 79,063 & 104,578 & & \\
\hline Kaolack & Senegal & 0 & 153,840 & 199,066 & & \\
\hline Kolda & Senegal & 0 & 36,624 & 71,134 & & \\
\hline Richard-Toll & Senegal & 0 & 36,610 & 67,954 & & \\
\hline Saint-Louis & Senegal & 0 & 118,992 & 188,160 & & \\
\hline Tambacounda & Senegal & 0 & 44,844 & 90,956 & & \\
\hline Touba-Mosquée & Senegal & 0 & 168,853 & 781,727 & & \\
\hline Ziguinchor & Senegal & 0 & 128,061 & 168,198 & & \\
\hline Bo & Sierra Leone & 1 & 76,138 & 220,890 & & \\
\hline Kenema & Sierra Leone & 1 & 66,406 & 187,158 & & \\
\hline
\end{tabular}


Continue: Table A1 sample cities and population

\begin{tabular}{|c|c|c|c|c|c|c|}
\hline City name & Country & $\begin{array}{l}\text { Anglphone } \\
\text { dummy }\end{array}$ & $\begin{array}{c}\text { Projected } \\
\text { population } \\
1990\end{array}$ & $\begin{array}{c}\text { Projected } \\
\text { population } \\
2012\end{array}$ & $\begin{array}{c}\text { Strict } \\
\text { colonial } \\
\text { origin } \\
\text { sample }\end{array}$ & $\begin{array}{l}40 \text { cities } \\
\text { sample }\end{array}$ \\
\hline Makeni & Sierra Leone & 1 & 48,170 & 108,671 & & \\
\hline Torgbonbu & Sierra Leone & 1 & 95,889 & 98,014 & & \\
\hline Waterloo & Sierra Leone & 1 & 561,004 & $1,049,768$ & Yes & Yes \\
\hline Ad-Damazin & Sudan & 1 & 58,786 & 255,340 & & \\
\hline Ad-Duwaym & Sudan & 1 & 53,580 & 79,009 & & \\
\hline Al-Fashir & Sudan & 1 & 130,226 & 244,208 & & \\
\hline Al-Junaynah & Sudan & 1 & 80,450 & 229,835 & & \\
\hline Al-Manaqil & Sudan & 1 & 60,108 & 111,669 & & \\
\hline An-Nuhud & Sudan & 1 & 52,539 & 69,668 & & \\
\hline Atbara & Sudan & 1 & 121,082 & 330,905 & Yes & \\
\hline Bur-Sudan & Sudan & 1 & 293,338 & 421,429 & & Yes \\
\hline El-Duein & Sudan & 1 & 64,709 & 161,998 & & \\
\hline El-Obeid & Sudan & 1 & 211,433 & 384,829 & Yes & \\
\hline Gedaref & Sudan & 1 & 178,488 & 295,201 & & \\
\hline Kaduqli & Sudan & 1 & 61,151 & 68,492 & & \\
\hline Kassala & Sudan & 1 & 223,586 & 318,335 & Yes & \\
\hline New-Halfa & Sudan & 1 & 52,391 & 66,386 & & \\
\hline Nyala & Sudan & 1 & 194,574 & 606,115 & & \\
\hline Sannar & Sudan & 1 & 58,718 & 266,989 & & \\
\hline Ngwenya & Swaziland & 1 & 82,878 & & Yes & \\
\hline Tabankulu & Swaziland & 1 & 30,730 & & & \\
\hline Arusha & Tanzania & 1 & 122,068 & 416,442 & & \\
\hline Bukoba & Tanzania & 1 & 31,826 & 128,796 & & \\
\hline Dar-es-Salaam & Tanzania & 1 & $1,333,413$ & $4,520,658$ & & Yes \\
\hline Dodoma & Tanzania & 1 & 90,565 & 213,636 & & \\
\hline
\end{tabular}


Continue: Table A1 sample cities and population

\begin{tabular}{|c|c|c|c|c|c|c|}
\hline City name & Country & $\begin{array}{l}\text { Anglphone } \\
\text { dummy }\end{array}$ & $\begin{array}{c}\text { Projected } \\
\text { population } \\
1990\end{array}$ & $\begin{array}{c}\text { Projected } \\
\text { population } \\
2012\end{array}$ & $\begin{array}{c}\text { Strict } \\
\text { colonial } \\
\text { origin } \\
\text { sample }\end{array}$ & $\begin{array}{l}40 \text { cities } \\
\text { sample }\end{array}$ \\
\hline Kigoma & Tanzania & 1 & 80,568 & 215,458 & & \\
\hline Lindi & Tanzania & 1 & 39,534 & 78,841 & & \\
\hline Mbeya & Tanzania & 1 & 144,556 & 385,279 & & Yes \\
\hline Mtwara & Tanzania & 1 & 68,149 & 100,626 & & \\
\hline Musoma & Tanzania & 1 & 68,356 & 134,327 & & \\
\hline Mwanza & Tanzania & 1 & 193,317 & 706,453 & Yes & \\
\hline Shinyanga & Tanzania & 1 & 49,960 & 103,795 & & \\
\hline Singida & Tanzania & 1 & 41,807 & 85,242 & & \\
\hline Songea & Tanzania & 1 & 57,908 & 203,309 & & \\
\hline Sumbawanga & Tanzania & 1 & 51,038 & 124,204 & & \\
\hline Tabora & Tanzania & 1 & 96,935 & 160,608 & & \\
\hline Tanga & Tanzania & 1 & 142,799 & 221,127 & Yes & \\
\hline Zanzibar & Tanzania & 1 & 174,467 & 501,459 & Yes & \\
\hline Fort-Portal & Uganda & 1 & 32,130 & 51,795 & & \\
\hline Gulu & Uganda & 1 & 34,535 & 146,233 & & \\
\hline Kampala & Uganda & 1 & 803,069 & $2,269,969$ & Yes & \\
\hline Masaka & Uganda & 1 & 47,671 & 112,864 & Yes & \\
\hline Mbale & Uganda & 1 & 51,446 & 117,706 & & \\
\hline Mbarara & Uganda & 1 & 39,119 & 164,150 & Yes & \\
\hline Njeru & Uganda & 1 & 96,824 & 219,039 & & \\
\hline Soroti & Uganda & 1 & 40,903 & 48,069 & & \\
\hline Chipata & Zambia & 1 & 52,213 & 128,045 & & \\
\hline Choma & Zambia & 1 & 30,143 & 54,492 & & \\
\hline Kabwe & Zambia & 1 & 154,318 & 207,909 & Yes & \\
\hline Kasama & Zambia & 1 & 47,653 & 108,492 & & \\
\hline
\end{tabular}


Continue: Table A1 sample cities and population

\begin{tabular}{|c|c|c|c|c|c|c|}
\hline City name & Country & $\begin{array}{l}\text { Anglphone } \\
\text { dummy }\end{array}$ & $\begin{array}{c}\text { Projected } \\
\text { population } \\
1990\end{array}$ & $\begin{array}{c}\text { Projected } \\
\text { population } \\
2012\end{array}$ & $\begin{array}{c}\text { Strict } \\
\text { colonial } \\
\text { origin } \\
\text { sample }\end{array}$ & $\begin{array}{c}40 \text { cities } \\
\text { sample }\end{array}$ \\
\hline Kitwe & Zambia & 1 & 355,793 & $1,066,992$ & Yes & Yes \\
\hline Livingstone & Zambia & 1 & 76,875 & 143,249 & Yes & \\
\hline Luanshya & Zambia & 1 & 118,143 & 133,187 & Yes & \\
\hline Lusaka & Zambia & 1 & 813,154 & $2,000,916$ & Yes & \\
\hline Mansa & Zambia & 1 & 37,882 & 88,890 & & \\
\hline Ndola & Zambia & 1 & 329,228 & 468,324 & Yes & \\
\hline Bulawayo & Zimbabwe & 1 & 611,307 & 653,337 & Yes & \\
\hline Chinhoyi & Zimbabwe & 1 & 41,969 & 68,273 & Yes & \\
\hline Gweru & Zimbabwe & 1 & 125,626 & 154,825 & Yes & \\
\hline Harare & Zimbabwe & 1 & $1,405,753$ & $2,133,801$ & Yes & \\
\hline Hwange & Zimbabwe & 1 & 44,297 & 19,870 & & \\
\hline Kadoma & Zimbabwe & 1 & 66,150 & 91,633 & Yes & \\
\hline Kwekwe & Zimbabwe & 1 & 101,681 & 136,804 & Yes & \\
\hline Marondera & Zimbabwe & 1 & 37,277 & 61,998 & & \\
\hline Masvingo & Zimbabwe & 1 & 48,780 & 87,886 & & \\
\hline Mutare & Zimbabwe & 1 & 124,697 & 186,208 & Yes & \\
\hline Zvishavane & Zimbabwe & 1 & 32,571 & 45,230 & & \\
\hline
\end{tabular}

Notes: Two cities are only included in the 40 cities sample, but not included in the 333 cities full sample. They are Bimbo in Central African Republic, Libreville in Gabon. 
Table A2: Intensity at grids level

\begin{tabular}{|c|c|c|c|c|c|c|c|}
\hline & $\begin{array}{l}\text { Has developed in } 2014 \\
\text { All grids } \\
\text { (1) }\end{array}$ & \multicolumn{2}{|c|}{$\begin{array}{l}\text { Has developed in } 2014 \\
\text { Undeveloped grids in } 1990\end{array}$} & $\begin{array}{c}\text { Ln intensity } 2014 \\
\text { Developed grids in } 1990 \\
(4) \\
\end{array}$ & \multicolumn{2}{|c|}{$\begin{array}{l}\text { Difference of } \ln \text { intensification 90-14 } \\
\text { Developed grids in } 1990\end{array}$} & $\begin{array}{c}\text { Ln intensity } 2014 \\
\text { New developed grids } \\
(7)\end{array}$ \\
\hline Anglophone country & $\begin{array}{l}-0.0691 \\
(0.0421)\end{array}$ & $\begin{array}{c}0.0142 \\
(0.0263)\end{array}$ & $\begin{array}{c}0.0294 \\
(0.0234)\end{array}$ & $\begin{array}{c}-0.252^{* *} \\
(0.118)\end{array}$ & $\begin{array}{c}0.265^{* * *} \\
(0.0715)\end{array}$ & $\begin{array}{c}0.0461 \\
(0.0752)\end{array}$ & $\begin{array}{r}-0.0882 \\
(0.156)\end{array}$ \\
\hline Distance to center & $\begin{array}{c}-0.00841^{* * *} \\
(0.00102)\end{array}$ & $\begin{array}{c}-0.00310^{* * *} \\
(0.000546)\end{array}$ & $\begin{array}{c}-0.00157^{* * *} \\
(0.000448)\end{array}$ & $\begin{array}{c}-0.0356^{* * *} \\
(0.00452)\end{array}$ & $\begin{array}{c}0.00636^{* * *} \\
(0.00236)\end{array}$ & $\begin{array}{c}-0.0114^{* * *} \\
(0.00261)\end{array}$ & $\begin{array}{c}-0.0257^{* * *} \\
(0.00444)\end{array}$ \\
\hline Distance to center $\times$ Anglophone & $\begin{array}{c}0.00617^{* * *} \\
(0.00177)\end{array}$ & $\begin{array}{c}0.00224^{* * *} \\
(0.000840)\end{array}$ & $\begin{array}{c}0.00101 \\
(0.000631)\end{array}$ & $\begin{array}{c}0.0209^{* * *} \\
(0.00663)\end{array}$ & $\begin{array}{l}-0.00373 \\
(0.00247)\end{array}$ & $\begin{array}{c}0.00671^{* *} \\
(0.00305)\end{array}$ & $\begin{array}{c}0.0152^{* * *} \\
(0.00509)\end{array}$ \\
\hline Ln intensity 1990 & & & & & & $\begin{array}{c}-0.423^{* * *} \\
(0.0156)\end{array}$ & \\
\hline Fraction of undeveloped area in ring 1990 & & & $\begin{array}{c}-0.947 * * * \\
(0.0878)\end{array}$ & & & & \\
\hline Ln income per capita 1990 & $\begin{array}{l}0.00548 \\
(0.0239)\end{array}$ & $\begin{array}{l}0.00697 \\
(0.0166)\end{array}$ & $\begin{array}{l}0.00767 \\
(0.0155)\end{array}$ & $\begin{array}{l}-0.0326 \\
(0.0755)\end{array}$ & $\begin{array}{l}-0.0132 \\
(0.0568)\end{array}$ & $\begin{array}{l}-0.0214 \\
(0.0563)\end{array}$ & $\begin{array}{c}0.0561 \\
(0.0756)\end{array}$ \\
\hline Ln projected city population 1990 & $\begin{array}{c}0.0796^{* * *} \\
(0.0131)\end{array}$ & $\begin{array}{c}0.0445^{* * *} \\
(0.00916)\end{array}$ & $\begin{array}{c}0.0348^{* * *} \\
(0.00831)\end{array}$ & $\begin{array}{c}0.201 * * * \\
(0.0290)\end{array}$ & $\begin{array}{l}-0.0295 \\
(0.0265)\end{array}$ & $\begin{array}{c}0.0681^{* * *} \\
(0.0235)\end{array}$ & $\begin{array}{c}0.138^{* * *} \\
(0.0425)\end{array}$ \\
\hline Ln country light growth 92 to 12 excluding own city & $\begin{array}{l}-0.0186 \\
(0.0325)\end{array}$ & $\begin{array}{l}0.00594 \\
(0.0245)\end{array}$ & $\begin{array}{l}0.00727 \\
(0.0229)\end{array}$ & $\begin{array}{l}-0.00975 \\
(0.0875)\end{array}$ & $\begin{array}{c}0.0864 \\
(0.0678)\end{array}$ & $\begin{array}{c}0.0457 \\
(0.0653)\end{array}$ & $\begin{array}{l}-0.0620 \\
(0.123)\end{array}$ \\
\hline Ln ruggedness & $\begin{array}{l}0.00683 \\
(0.0160)\end{array}$ & $\begin{array}{c}0.00270 \\
(0.00999)\end{array}$ & $\begin{array}{c}0.00414 \\
(0.00914)\end{array}$ & $\begin{array}{l}-0.0446 \\
(0.0414)\end{array}$ & $\begin{array}{c}0.0383 \\
(0.0424)\end{array}$ & $\begin{array}{l}0.00320 \\
(0.0360)\end{array}$ & $\begin{array}{l}-0.0634 \\
(0.0515)\end{array}$ \\
\hline Ln rainfall & $\begin{array}{c}0.0738^{* *} \\
(0.0302)\end{array}$ & $\begin{array}{c}0.0631^{* * *} \\
(0.0184)\end{array}$ & $\begin{array}{c}0.0538^{* * *} \\
(0.0159)\end{array}$ & $\begin{array}{c}0.124 \\
(0.0911)\end{array}$ & $\begin{array}{l}0.138^{* *} \\
(0.0555)\end{array}$ & $\begin{array}{l}0.132^{* *} \\
(0.0638)\end{array}$ & $\begin{array}{l}0.0860 \\
(0.103)\end{array}$ \\
\hline Ln elevation range & $\begin{array}{c}-0.0486^{* *} \\
(0.0219)\end{array}$ & $\begin{array}{l}-0.0261^{*} \\
(0.0136)\end{array}$ & $\begin{array}{c}-0.0228^{*} \\
(0.0121)\end{array}$ & $\begin{array}{l}-0.0466 \\
(0.0672)\end{array}$ & $\begin{array}{c}0.0146 \\
(0.0579)\end{array}$ & $\begin{array}{c}-0.0113 \\
(0.0546)\end{array}$ & $\begin{array}{c}0.0262 \\
(0.0872)\end{array}$ \\
\hline Coast dummy & $\begin{array}{l}-0.361 \\
(0.578)\end{array}$ & $\begin{array}{l}-0.470 \\
(0.325)\end{array}$ & $\begin{array}{l}-0.457 \\
(0.294)\end{array}$ & $\begin{array}{c}-3.167^{* *} \\
(1.456)\end{array}$ & $\begin{array}{l}-1.932 \\
(1.471)\end{array}$ & $\begin{array}{c}-2.454^{* *} \\
(1.220)\end{array}$ & $\begin{array}{l}-4.872^{*} \\
(2.737)\end{array}$ \\
\hline Ln coast length $\times$ coast dummy & $\begin{array}{c}0.0826 \\
(0.0533)\end{array}$ & $\begin{array}{c}0.0594^{* *} \\
(0.0297)\end{array}$ & $\begin{array}{l}0.0513^{*} \\
(0.0266)\end{array}$ & $\begin{array}{l}0.324^{* *} \\
(0.134)\end{array}$ & $\begin{array}{l}0.114 \\
(0.127)\end{array}$ & $\begin{array}{l}0.202^{*} \\
(0.105)\end{array}$ & $\begin{array}{c}0.506^{* *} \\
(0.216)\end{array}$ \\
\hline Ln distance to coast $\times$ coast dummy & $\begin{array}{c}-0.0708^{* *} \\
(0.0286)\end{array}$ & $\begin{array}{l}-0.0290^{*} \\
(0.0172)\end{array}$ & $\begin{array}{l}-0.0237^{*} \\
(0.0140)\end{array}$ & $\begin{array}{l}-0.0579 \\
(0.0691)\end{array}$ & $\begin{array}{c}0.0704 \\
(0.0535)\end{array}$ & $\begin{array}{c}0.0161 \\
(0.0455)\end{array}$ & $\begin{array}{l}-0.0822 \\
(0.110)\end{array}$ \\
\hline Fraction of river area & $\begin{array}{c}0.167 \\
(0.506)\end{array}$ & $\begin{array}{r}-0.0534 \\
(0.255)\end{array}$ & $\begin{array}{l}-0.138 \\
(0.224)\end{array}$ & $\begin{array}{l}-0.132 \\
(1.233)\end{array}$ & $\begin{array}{l}-1.132 \\
(1.489)\end{array}$ & $\begin{array}{l}-0.708 \\
(1.141)\end{array}$ & $\begin{array}{l}-0.862 \\
(1.781)\end{array}$ \\
\hline Fraction of lake area & $\begin{array}{c}0.522 \\
(0.560)\end{array}$ & $\begin{array}{c}0.00995 \\
(0.363)\end{array}$ & $\begin{array}{l}-0.0140 \\
(0.290)\end{array}$ & $\begin{array}{l}2.465^{*} \\
(1.451)\end{array}$ & $\begin{array}{c}-1.521 \\
(1.258)\end{array}$ & $\begin{array}{c}0.166 \\
(1.101)\end{array}$ & $\begin{array}{c}0.451 \\
(2.312)\end{array}$ \\
\hline Fraction of forest & $\begin{array}{c}0.0871 \\
(0.0752)\end{array}$ & $\begin{array}{c}0.0156 \\
(0.0477)\end{array}$ & $\begin{array}{l}-0.00303 \\
(0.0414)\end{array}$ & $\begin{array}{l}-0.113 \\
(0.214)\end{array}$ & $\begin{array}{c}-0.460 * * * \\
(0.152)\end{array}$ & $\begin{array}{c}-0.313^{* *} \\
(0.152)\end{array}$ & $\begin{array}{l}-0.0607 \\
(0.216)\end{array}$ \\
\hline Fraction of shrubs & $\begin{array}{c}0.133^{*} \\
(0.0768)\end{array}$ & $\begin{array}{c}0.0874 \\
(0.0542)\end{array}$ & $\begin{array}{l}0.0821^{*} \\
(0.0495)\end{array}$ & $\begin{array}{l}0.130 \\
(0.184)\end{array}$ & $\begin{array}{r}-0.0873 \\
(0.152)\end{array}$ & $\begin{array}{l}0.00473 \\
(0.140)\end{array}$ & $\begin{array}{l}0.136 \\
(0.220)\end{array}$ \\
\hline Fraction of crops & $\begin{array}{c}0.0951 \\
(0.0715)\end{array}$ & $\begin{array}{c}0.0539 \\
(0.0478)\end{array}$ & $\begin{array}{c}0.0342 \\
(0.0423)\end{array}$ & $\begin{array}{l}0.350^{*} \\
(0.191)\end{array}$ & $\begin{array}{c}-0.0812 \\
(0.132)\end{array}$ & $\begin{array}{c}0.101 \\
(0.143)\end{array}$ & $\begin{array}{c}0.316 \\
(0.207)\end{array}$ \\
\hline Fraction of wetlands and water & $\begin{array}{c}0.800^{* * *} \\
(0.274)\end{array}$ & $\begin{array}{c}0.625^{* * *} \\
(0.193)\end{array}$ & $\begin{array}{c}0.259 \\
(0.199)\end{array}$ & $\begin{array}{c}2.249^{* * *} \\
(0.714)\end{array}$ & $\begin{array}{c}0.362 \\
(0.575)\end{array}$ & $\begin{array}{l}1.161^{* * *} \\
(0.533)\end{array}$ & $\begin{array}{l}2.152^{*} \\
(1.216)\end{array}$ \\
\hline Fraction of sparse vege and bare land & $\begin{array}{c}0.0471 \\
(0.0912)\end{array}$ & $\begin{array}{c}0.0378 \\
(0.0527)\end{array}$ & $\begin{array}{c}0.0296 \\
(0.0452)\end{array}$ & $\begin{array}{c}0.408 \\
(0.378)\end{array}$ & $\begin{array}{l}-0.193 \\
(0.192)\end{array}$ & $\begin{array}{l}0.0611 \\
(0.207)\end{array}$ & $\begin{array}{c}0.541 \\
(0.499)\end{array}$ \\
\hline Observations & 487,693 & 379,987 & 379,987 & 107,706 & 107,706 & 107,706 & 71,579 \\
\hline R-squared & 0.096 & 0.046 & 0.074 & 0.116 & 0.026 & 0.435 & 0.043 \\
\hline
\end{tabular}

Notes: Column 1 estimates a linear probability model (LPM) of whether a grid square is developed or not in 2014 for all grids. Columns 2 and 3 estimates an LPM of whether the undeveloped grid squares in 1990 have developed in 2014. Column 4 shows 2014 development intensity of 1990 grid squares which had built areas. Columns 5 and 6 show intensification within 1990 developed grid squares. Column 7 shows 2014 intensity in newly developed grid squares

Standard errors are clustered at city level

${ }^{* * *} \mathrm{p}<0.01,{ }^{* *} \mathrm{p}<0.05,{ }^{*} \mathrm{p}<0.1$ 
Table A3: Intensity and convergence: Robustness to city boundary definitions

\begin{tabular}{|c|c|c|c|c|c|c|}
\hline & \multicolumn{2}{|c|}{ Ln ring built cover } & \multirow[b]{2}{*}{$\begin{array}{c}30 \mathrm{~km} \text { light } 0 \\
(3)\end{array}$} & \multicolumn{2}{|c|}{ Long Difference of ln ring built cover } & \multirow[b]{2}{*}{$\begin{array}{c}\text { Trim light } 5 \\
\text { drop mins and maxes } \\
(6)\end{array}$} \\
\hline & $\begin{array}{c}30 \mathrm{~km} \text { light } 0 \\
(1)\end{array}$ & $\begin{array}{c}\text { Trim light } 5 \\
\text { drop mins and maxes } \\
(2)\end{array}$ & & $\begin{array}{c}30 \mathrm{~km} \text { light } 0 \\
(4)\end{array}$ & $\begin{array}{c}\text { Trim light } 5 \\
\text { drop mins and maxes } \\
(5)\end{array}$ & \\
\hline Anglophone country & $\begin{array}{c}-0.509^{* *} \\
(0.201)\end{array}$ & $\begin{array}{c}-0.658^{* * *} \\
(0.233)\end{array}$ & $\begin{array}{c}0.256 * * * \\
(0.0953)\end{array}$ & $\begin{array}{c}0.0804 \\
(0.0848)\end{array}$ & $\begin{array}{c}0.355^{* * *} \\
(0.101)\end{array}$ & $\begin{array}{c}0.0811 \\
(0.0972)\end{array}$ \\
\hline Ring distance & $\begin{array}{c}-0.170^{* * * *} \\
(0.0172)\end{array}$ & $\begin{array}{c}-0.250^{* * *} \\
(0.0299)\end{array}$ & $\begin{array}{c}0.0230^{* *} \\
(0.00900)\end{array}$ & $\begin{array}{c}-0.0298^{* * *} \\
(0.00731)\end{array}$ & $\begin{array}{c}0.0666^{* * *} \\
(0.0127)\end{array}$ & $\begin{array}{l}-0.0288^{*} \\
(0.0156)\end{array}$ \\
\hline Ring distance $\times$ Anglophone & $\begin{array}{c}0.0433^{* *} \\
(0.0187)\end{array}$ & $\begin{array}{l}0.108^{* * *} \\
(0.0326)\end{array}$ & $\begin{array}{c}-0.000565 \\
(0.00973)\end{array}$ & $\begin{array}{c}0.0119 \\
(0.00739)\end{array}$ & $\begin{array}{c}-0.0246^{*} \\
(0.0136)\end{array}$ & $\begin{array}{c}0.0174 \\
(0.0145)\end{array}$ \\
\hline Ln ring total pixel & $\begin{array}{c}0.731 * * * \\
(0.0417)\end{array}$ & $\begin{array}{c}0.691 * * * \\
(0.0451)\end{array}$ & $\begin{array}{c}0.167^{* * *} \\
(0.0268)\end{array}$ & $\begin{array}{l}0.302 * * * \\
(0.0235)\end{array}$ & $\begin{array}{c}0.217^{* * *} \\
(0.0296)\end{array}$ & $\begin{array}{c}0.332 * * * \\
(0.0236)\end{array}$ \\
\hline Ln ring built cover in 1990 & & & & $\begin{array}{c}-0.296^{* * *} \\
(0.0161)\end{array}$ & & $\begin{array}{c}-0.319^{* * *} \\
(0.0200)\end{array}$ \\
\hline Ln income per Capita 1990 & $\begin{array}{l}-0.0447 \\
(0.145)\end{array}$ & $\begin{array}{l}-0.0990 \\
(0.147)\end{array}$ & $\begin{array}{c}0.148 \\
(0.0922)\end{array}$ & $\begin{array}{c}0.0791 \\
(0.0833)\end{array}$ & $\begin{array}{c}0.160^{*} \\
(0.0875)\end{array}$ & $\begin{array}{c}0.0775 \\
(0.0700)\end{array}$ \\
\hline Ln projected city population 1990 & $\begin{array}{c}0.830^{* * *} \\
(0.0739)\end{array}$ & $\begin{array}{c}0.899^{* * *} * \\
(0.0869)\end{array}$ & $\begin{array}{c}-0.151^{* * *} \\
(0.0323)\end{array}$ & $\begin{array}{c}0.117^{* * *} \\
(0.0321)\end{array}$ & $\begin{array}{c}-0.200^{* * * *} \\
(0.0371)\end{array}$ & $\begin{array}{c}0.126^{* * *} \\
(0.0413)\end{array}$ \\
\hline Ln country light growth 92 to 12 excluding own city & $\begin{array}{l}0.00573 \\
(0.153)\end{array}$ & $\begin{array}{c}0.244 \\
(0.203)\end{array}$ & $\begin{array}{l}0.0269 \\
(0.108)\end{array}$ & $\begin{array}{l}0.0753 \\
(0.0909)\end{array}$ & $\begin{array}{r}-0.0264 \\
(0.103)\end{array}$ & $\begin{array}{c}0.114 \\
(0.0855)\end{array}$ \\
\hline Ln ruggedness & $\begin{array}{l}-0.0218 \\
(0.0657)\end{array}$ & $\begin{array}{l}-0.0499 \\
(0.0638)\end{array}$ & $\begin{array}{c}0.0709 \\
(0.0433)\end{array}$ & $\begin{array}{c}0.0478 \\
(0.0362)\end{array}$ & $\begin{array}{c}0.0863 * * \\
(0.0394)\end{array}$ & $\begin{array}{c}0.0455 \\
(0.0322)\end{array}$ \\
\hline Ln rainfall & $\begin{array}{c}0.125 \\
(0.149)\end{array}$ & $\begin{array}{l}0.0996 \\
(0.136)\end{array}$ & $\begin{array}{c}0.292^{* * *} \\
(0.0725)\end{array}$ & $\begin{array}{c}0.256^{* * *} \\
(0.0752)\end{array}$ & $\begin{array}{c}0.326^{* * *} \\
(0.0706)\end{array}$ & $\begin{array}{c}0.263^{* * *} \\
(0.0599)\end{array}$ \\
\hline Ln elevation range & $\begin{array}{c}0.240^{* *} \\
(0.100)\end{array}$ & $\begin{array}{l}0.244^{* *} \\
(0.111)\end{array}$ & $\begin{array}{c}-0.136^{* *} \\
(0.0638)\end{array}$ & $\begin{array}{l}-0.0454 \\
(0.0570)\end{array}$ & $\begin{array}{c}-0.189 * * * \\
(0.0629)\end{array}$ & $\begin{array}{l}-0.0776 \\
(0.0506)\end{array}$ \\
\hline Coastal Dummy & $\begin{array}{c}0.368 \\
(3.367)\end{array}$ & $\begin{array}{l}-8.758 \\
(6.354)\end{array}$ & $\begin{array}{c}0.143 \\
(1.044)\end{array}$ & $\begin{array}{l}-0.498 \\
(1.332)\end{array}$ & $\begin{array}{c}-4.158^{*} \\
(2.331)\end{array}$ & $\begin{array}{c}-6.326^{* * *} \\
(2.244)\end{array}$ \\
\hline Ln coast length $\times$ coast dummy & $\begin{array}{l}0.0656 \\
(0.304)\end{array}$ & $\begin{array}{c}0.459 \\
(0.519)\end{array}$ & $\begin{array}{c}0.0303 \\
(0.0855)\end{array}$ & $\begin{array}{l}0.0811 \\
(0.122)\end{array}$ & $\begin{array}{l}0.298^{*} \\
(0.168)\end{array}$ & $\begin{array}{c}0.392^{* *} \\
(0.191)\end{array}$ \\
\hline Ln distance to coast $\times$ coast dummy & $\begin{array}{r}-0.0353 \\
(0.152)\end{array}$ & $\begin{array}{l}0.647^{*} \\
(0.358)\end{array}$ & $\begin{array}{l}-0.0577 \\
(0.0737)\end{array}$ & $\begin{array}{c}-0.0232 \\
(0.0714)\end{array}$ & $\begin{array}{c}0.168 \\
(0.143)\end{array}$ & $\begin{array}{c}0.346^{* * *} \\
(0.101)\end{array}$ \\
\hline Fraction of river area & $\begin{array}{l}-1.135 \\
(2.195)\end{array}$ & $\begin{array}{l}-1.103 \\
(2.177)\end{array}$ & $\begin{array}{c}0.544 \\
(1.104)\end{array}$ & $\begin{array}{l}0.0103 \\
(0.950)\end{array}$ & $\begin{array}{c}1.430 \\
(1.070)\end{array}$ & $\begin{array}{c}0.463 \\
(0.877)\end{array}$ \\
\hline Fraction of lake area & $\begin{array}{l}-2.439 \\
(3.307)\end{array}$ & $\begin{array}{l}-0.913 \\
(3.738)\end{array}$ & $\begin{array}{l}-0.402 \\
(1.119)\end{array}$ & $\begin{array}{l}-0.669 \\
(1.044)\end{array}$ & $\begin{array}{l}-0.221 \\
(1.130)\end{array}$ & $\begin{array}{c}0.104 \\
(0.856)\end{array}$ \\
\hline forest percent Ring & $\begin{array}{l}0.0764 \\
(0.359)\end{array}$ & $\begin{array}{c}-0.0118 \\
(0.420)\end{array}$ & $\begin{array}{c}-0.391^{* *} \\
(0.161)\end{array}$ & $\begin{array}{c}-0.314^{* *} \\
(0.153)\end{array}$ & $\begin{array}{l}-0.268 \\
(0.196)\end{array}$ & $\begin{array}{l}-0.272 \\
(0.189)\end{array}$ \\
\hline Shrubs percent Ring & $\begin{array}{l}-0.0461 \\
(0.332)\end{array}$ & $\begin{array}{l}-0.177 \\
(0.364)\end{array}$ & $\begin{array}{l}0.0447 \\
(0.143)\end{array}$ & $\begin{array}{l}0.0463 \\
(0.147)\end{array}$ & $\begin{array}{c}-0.00473 \\
(0.173)\end{array}$ & $\begin{array}{l}-0.0422 \\
(0.163)\end{array}$ \\
\hline Crops percent Ring & $\begin{array}{l}0.286 \\
(0.275)\end{array}$ & $\begin{array}{c}0.332 \\
(0.306)\end{array}$ & $\begin{array}{l}-0.295^{*} \\
(0.150)\end{array}$ & $\begin{array}{l}-0.190 \\
(0.143)\end{array}$ & $\begin{array}{l}-0.166 \\
(0.170)\end{array}$ & $\begin{array}{c}-0.102 \\
(0.152)\end{array}$ \\
\hline Wetlands and water percent Ring & $\begin{array}{l}2.184^{*} \\
(1.209)\end{array}$ & $\begin{array}{l}3.102^{* *} \\
(1.499)\end{array}$ & $\begin{array}{c}-1.556^{* * *} \\
(0.598)\end{array}$ & $\begin{array}{l}-0.544 \\
(0.544)\end{array}$ & $\begin{array}{c}-1.308^{* * *} \\
(0.504)\end{array}$ & $\begin{array}{c}-0.143 \\
(0.569)\end{array}$ \\
\hline SparseVege and Bare percent Ring & $\begin{array}{c}-2.187^{* * *} \\
(0.506)\end{array}$ & $\begin{array}{c}-2.095^{* * *} \\
(0.553)\end{array}$ & $\begin{array}{l}-0.224 \\
(0.194)\end{array}$ & $\begin{array}{c}-0.820^{* * * *} \\
(0.235)\end{array}$ & $\begin{array}{l}-0.185 \\
(0.253)\end{array}$ & $\begin{array}{c}-0.798^{* * *} \\
(0.219)\end{array}$ \\
\hline Observations & 4,082 & 2,945 & 3,755 & 3,755 & 2,680 & 2,680 \\
\hline R-squared & 0.451 & 0.417 & 0.124 & 0.470 & 0.143 & 0.502 \\
\hline
\end{tabular}


Table A4: Leapfrogging other specifications

\begin{tabular}{|c|c|c|c|c|}
\hline & $\begin{array}{l}\text { Count of LF patches } \\
\text { Poisson } \\
(1)\end{array}$ & $\begin{array}{c}\text { Ln count of leapfrog } \\
\text { OLS } \\
(2)\end{array}$ & $\begin{array}{c}\text { Ln count of leapfrog } \\
\text { Tobit } \\
(3)\end{array}$ & $\begin{array}{c}\text { Ln LF minus Ln total } \\
\text { OLS } \\
(4)\end{array}$ \\
\hline Anglophone country & $\begin{array}{c}0.480^{* *} \\
(0.190)\end{array}$ & $\begin{array}{c}0.681^{* * *} \\
(0.142)\end{array}$ & $\begin{array}{c}0.762^{* * *} \\
(0.148)\end{array}$ & $\begin{array}{c}0.274^{* *} \\
(0.104)\end{array}$ \\
\hline Ln initial built cover 1990 & $\begin{array}{l}0.407^{* * *} \\
(0.0615)\end{array}$ & $\begin{array}{c}0.357^{* * *} \\
(0.0456)\end{array}$ & $\begin{array}{l}0.354^{* * *} \\
(0.0504)\end{array}$ & $\begin{array}{c}-0.251^{* * *} \\
(0.0248)\end{array}$ \\
\hline Year Dummy 2014 & $\begin{array}{c}0.580^{* * *} \\
(0.0925)\end{array}$ & $\begin{array}{c}0.469^{* * *} \\
(0.101)\end{array}$ & $\begin{array}{c}0.493^{* * *} \\
(0.102)\end{array}$ & $\begin{array}{c}0.117^{*} \\
(0.0627)\end{array}$ \\
\hline Ln income per capita t- 1 & $\begin{array}{c}0.199 \\
(0.132)\end{array}$ & $\begin{array}{l}0.245^{* *} \\
(0.0988)\end{array}$ & $\begin{array}{c}0.225 \\
(0.156)\end{array}$ & $\begin{array}{c}0.0199 \\
(0.0477)\end{array}$ \\
\hline Ln projected city population 1990 & $\begin{array}{l}0.437^{* * *} \\
(0.0911)\end{array}$ & $\begin{array}{l}0.548^{* * *} \\
(0.0817)\end{array}$ & $\begin{array}{c}0.647^{* * *} \\
(0.0863)\end{array}$ & $\begin{array}{l}0.319^{* * *} \\
(0.0434)\end{array}$ \\
\hline Ln country light growth excluding own city & $\begin{array}{c}0.446^{* * *} * \\
(0.173)\end{array}$ & $\begin{array}{c}0.631^{* * *} \\
(0.138)\end{array}$ & $\begin{array}{c}0.650^{* * *} \\
(0.177)\end{array}$ & $\begin{array}{c}0.430 * * * \\
(0.0768)\end{array}$ \\
\hline Ln ruggedness & $\begin{array}{l}-0.0417 \\
(0.0531)\end{array}$ & $\begin{array}{l}-0.0151 \\
(0.0564)\end{array}$ & $\begin{array}{l}-0.0153 \\
(0.0592)\end{array}$ & $\begin{array}{c}-0.0838^{* *} \\
(0.0340)\end{array}$ \\
\hline Ln rainfall & $\begin{array}{c}-0.371^{* * *} \\
(0.113)\end{array}$ & $\begin{array}{l}-0.253^{* *} \\
(0.0962)\end{array}$ & $\begin{array}{c}-0.365^{* * *} \\
(0.113)\end{array}$ & $\begin{array}{l}-0.0930 \\
(0.0730)\end{array}$ \\
\hline Ln elevation range & $\begin{array}{c}0.433^{* * *} \\
(0.0752)\end{array}$ & $\begin{array}{c}0.491^{* * * *} \\
(0.0592)\end{array}$ & $\begin{array}{c}0.489^{* * *} * \\
(0.0708)\end{array}$ & $\begin{array}{c}0.245^{* * *} \\
(0.0431)\end{array}$ \\
\hline Coast dummy & $\begin{array}{c}-5.893^{*} \\
(3.162)\end{array}$ & $\begin{array}{c}-7.498^{* * *} \\
(2.777)\end{array}$ & $\begin{array}{c}-7.415^{* *} \\
(3.041)\end{array}$ & $\begin{array}{c}-8.212^{* * *} \\
(1.793)\end{array}$ \\
\hline Ln coast length $\times$ coast dummy & $\begin{array}{l}0.354 \\
(0.296)\end{array}$ & $\begin{array}{l}0.513^{*} \\
(0.265)\end{array}$ & $\begin{array}{l}0.490 \\
(0.299)\end{array}$ & $\begin{array}{c}0.522^{* * *} \\
(0.156)\end{array}$ \\
\hline Ln distance to coast $\times$ coast dummy & $\begin{array}{l}0.198^{* *} \\
(0.0910)\end{array}$ & $\begin{array}{l}0.210 \\
(0.137)\end{array}$ & $\begin{array}{l}0.239 \\
(0.158)\end{array}$ & $\begin{array}{c}0.309^{* *} \\
(0.118)\end{array}$ \\
\hline Fraction of river area & $\begin{array}{l}-3.502^{*} \\
(2.056)\end{array}$ & $\begin{array}{l}1.896 \\
(1.661)\end{array}$ & $\begin{array}{l}1.149 \\
(1.907)\end{array}$ & $\begin{array}{c}0.530 \\
(0.999)\end{array}$ \\
\hline Fraction of lake area & $\begin{array}{l}-0.858 \\
(1.613)\end{array}$ & $\begin{array}{c}-3.379^{* *} \\
(1.367)\end{array}$ & $\begin{array}{c}-3.086^{* *} \\
(1.448)\end{array}$ & $\begin{array}{c}-3.392^{* *} \\
(1.325)\end{array}$ \\
\hline Fraction of forest & $\begin{array}{c}0.194 \\
(0.379)\end{array}$ & $\begin{array}{c}0.00879 \\
(0.229)\end{array}$ & $\begin{array}{l}-0.0758 \\
(0.287)\end{array}$ & $\begin{array}{l}-0.216 \\
(0.139)\end{array}$ \\
\hline Fraction of shrubs & $\begin{array}{c}0.714^{* * *} \\
(0.272)\end{array}$ & $\begin{array}{l}0.462^{*} \\
(0.243)\end{array}$ & $\begin{array}{l}0.575^{* *} \\
(0.247)\end{array}$ & $\begin{array}{l}0.0556 \\
(0.125)\end{array}$ \\
\hline Fraction of crops & $\begin{array}{l}0.341 \\
(0.321)\end{array}$ & $\begin{array}{l}0.0377 \\
(0.195)\end{array}$ & $\begin{array}{l}-0.0314 \\
(0.234)\end{array}$ & $\begin{array}{c}-0.0952 \\
(0.133)\end{array}$ \\
\hline Fraction of wetlands and water & $\begin{array}{l}1.258 \\
(1.336)\end{array}$ & $\begin{array}{c}0.498 \\
(0.890)\end{array}$ & $\begin{array}{c}1.017 \\
(0.928)\end{array}$ & $\begin{array}{c}0.826 \\
(0.586)\end{array}$ \\
\hline Fraction of sparse vege and bare land & $\begin{array}{c}-0.993^{* *} \\
(0.389)\end{array}$ & $\begin{array}{c}-1.134^{* * *} \\
(0.324)\end{array}$ & $\begin{array}{c}-1.973^{* * *} \\
(0.527)\end{array}$ & $\begin{array}{c}-0.807^{* * *} \\
(0.228)\end{array}$ \\
\hline $\begin{array}{l}\text { Observations } \\
\text { R-squared }\end{array}$ & 606 & $\begin{array}{c}578 \\
0.622\end{array}$ & 606 & $\begin{array}{c}578 \\
0.236\end{array}$ \\
\hline
\end{tabular}

Notes: Standard errors are clustered at country year level

*** $\mathrm{p}<0.01,{ }^{* *} \mathrm{p}<0.05,{ }^{*} \mathrm{p}<0.1$ 
Table A5: Balance test for leapfrogging regressions

\begin{tabular}{|c|c|c|c|}
\hline & $\begin{array}{l}(1) \\
\text { Full sample }\end{array}$ & $\begin{array}{c}(2) \\
\text { Border sample }\end{array}$ & $\begin{array}{c}(3) \\
\text { Border sample }\end{array}$ \\
\hline Ln initial built cover 1990 & $\begin{array}{c}-.297^{* *} \\
(.132)\end{array}$ & $\begin{array}{c}-.554^{* * * *} \\
\quad(.21)\end{array}$ & $\begin{array}{l}-.237 \\
(.236)\end{array}$ \\
\hline Ln ratio of light 1992 to pop 1990 & $\begin{array}{c}.982^{* * *} \\
(.195)\end{array}$ & $\begin{array}{c}.259 \\
(.442)\end{array}$ & $\begin{array}{l}-.023 \\
(.313)\end{array}$ \\
\hline Ln projected city population 1990 & $\begin{array}{l}.104 \\
(.08)\end{array}$ & $\begin{array}{l}-.165 \\
(.169)\end{array}$ & $\begin{array}{l}-.049 \\
(.173)\end{array}$ \\
\hline Ln city light growth & $\begin{array}{c}-.441^{* * *} \\
(.115)\end{array}$ & $\begin{array}{l}-.203 \\
(.268)\end{array}$ & $\begin{array}{l}-.127 \\
(.253)\end{array}$ \\
\hline Ln ruggedness & $\begin{array}{c}.578 * * * \\
(.114)\end{array}$ & $\begin{array}{l}.437^{* *} \\
(.199)\end{array}$ & $\begin{array}{c}.038 \\
(.087)\end{array}$ \\
\hline Ln rainfall & $\begin{array}{c}.032 \\
(.056)\end{array}$ & $\begin{array}{l}-.006 \\
(.098)\end{array}$ & $\begin{array}{l}.148^{* * *} \\
(.027)\end{array}$ \\
\hline Ln elevation range & $\begin{array}{c}.298^{* * *} \\
(.06)\end{array}$ & $\begin{array}{l}.019 \\
(.135)\end{array}$ & $\begin{array}{c}.016 \\
(.103)\end{array}$ \\
\hline Coast dummy & $\begin{array}{c}-.036^{*} \\
(.019)\end{array}$ & $\begin{array}{l}.029 \\
(.045)\end{array}$ & $\begin{array}{l}.086 \\
(.056)\end{array}$ \\
\hline Fraction of river area & $\begin{array}{c}-.007^{* * * *} \\
(.003)\end{array}$ & $\begin{array}{l}-.006 \\
(.005)\end{array}$ & $\begin{array}{l}-.005 \\
(.003)\end{array}$ \\
\hline Fraction of lake area & $\begin{array}{c}.002 \\
(.002)\end{array}$ & $\begin{array}{c}0 \\
(.001)\end{array}$ & $\begin{array}{c}0 \\
(.001)\end{array}$ \\
\hline Ln coast length $\times$ coast dummy & $\begin{array}{l}-.376^{*} \\
(.203)\end{array}$ & $\begin{array}{l}.335 \\
(.485)\end{array}$ & $\begin{array}{l}.956 \\
(.609)\end{array}$ \\
\hline $\begin{array}{l}\text { City cluster FE } \\
\text { Observations }\end{array}$ & $\begin{array}{l}\text { No } \\
606\end{array}$ & $\begin{array}{l}\text { No } \\
113\end{array}$ & $\begin{array}{l}\text { Yes } \\
113\end{array}$ \\
\hline
\end{tabular}

Notes: Border sample does not include cities in Anglophone and Francophone Cameroon border area. Robust standard errors are applied.

*** $\mathrm{p}<0.01,{ }^{*} * \mathrm{p}<0.05,{ }^{*} \mathrm{p}<0.1$ 
$\mathrm{E} \cdot \mathrm{S} \cdot \mathrm{R} \cdot \mathrm{C}$

ECONOMIC

\& SOCIAL

RESEARCH

C OUNCIL

Spatial Economics Research Centre (SERC)

London School of Economics

Houghton Street

London WC2A 2AE

Web: www.spatialeconomics.ac.uk 